Florida International University FIU Digital Commons

11-13-2009

\title{
A lessons learned document for disputes in Florida Department of Transportation projects
}

Cagri Cinkilic

Florida International University

DOI: $10.25148 /$ etd.FI14060839

Follow this and additional works at: https://digitalcommons.fiu.edu/etd

Part of the Construction Engineering and Management Commons

\section{Recommended Citation}

Cinkilic, Cagri, "A lessons learned document for disputes in Florida Department of Transportation projects" (2009). FIU Electronic Theses and Dissertations. 2369.

https://digitalcommons.fiu.edu/etd/2369 
FLORIDA INTERNATIONAL UNIVERSITY

Miami, Florida

\section{A LESSONS LEARNED DOCUMENT FOR DISPUTES \\ IN FLORIDA DEPARTMENT OF TRANSPORTATION PROJECTS}

A thesis submitted in partial fulfillment of the requirements for the degree of

MASTER OF SCIENCE

in

CONSTRUCTION MANAGEMENT

by

Cagri Cinkilic

2009 
To: Dean Amir Mirmiran

College of Engineering and Computing

This thesis, written by Cagri Cinkilic, and entitled A Lessons Learned Document for Disputes in Florida Department of Transportation Projects, having been approved in respect to style and intellectual content, is referred to you for judgment.

We have read this thesis and recommend that it be approved.

Syed M. Ahmed

Yimin Zhu

Mehmet Emre Bayraktar, Major Professor

Date of Defense: November 13, 2009

The thesis of Cagri Cinkilic is approved.

Dean Amir Mirmiran College of Engineering and Computing

Dean George Walker University Graduate School

Florida International University, 2009 


\section{ABSTRACT OF THE THESIS \\ A LESSONS LEARNED DOCUMENT FOR DISPUTES IN FLORIDA \\ DEPARTMENT OF TRANSPORTATION PROJECTS}

by

Cagri Cinkilic

Florida International University, 2009

Miami, Florida

Professor Mehmet Emre Bayraktar

The purpose of this research is to identify, analyze and evaluate the current Florida Department of Transportation (FDOT) reports in DRB database and develop a utilized, user friendly lessons learned document for FDOT and contractor. The analysis of the reports in the DRB database illustrated that, most common disputes in governmental transportation projects in Florida are due to unforeseen conditions. Over the course of this research, lessons were developed according to the recommendations made by DRB agents at the end of each case in 262 reports. Parties involved in a FDOT project can check this document to avoid recurrence of the negative outcomes and promote recurrence of the positive outcomes. 


\section{TABLE OF CONTENTS}

1. INTRODUCTION

1.1. Introduction

1.2. Problem Statement

1.3. Research Objective

1.4. Research Methodology

1.4.1. Literature Review

1.4.2. Analysis of Disputes

1.4.3. Lessons Learned

1.5. Organization of the Thesis

2. LITERATURE REVIEW 6

2.1. Introduction 6

2.2. Definition of Disputes 6

2.3. Dispute Resolution Board Concept 14

2.3.1. What is DRB? 14

2.3.2. How does DRB work? 15

$\begin{array}{ll}\text { 2.3.3. DRB Benefits } & 17\end{array}$

2.3.4. DRB Limitations 18

2.4. Lessons Learned 19

2.4.1. What are Lessons Learned? 19

2.4.2. Lessons Learned Barriers $\quad 19$

2.4.3. Lessons Learned Benefits 20

2.4.4. Review of Lessons Learned 20

2.4.5. Who Are the Users of Lessons Learned? 21

2.5. Parties: Florida Department of Transportation (FDOT) and The Contractor 21

2.6. Summary 22

3. DISPUTE CHARACTERISTICS 23

3.1. Introduction 23

3.2. Characteristics of Disputes 23

3.2.1. Data \& Information 23

3.2.2. Data Analysis 26

3.2.2.1. District $1 \quad 27$

3.2.2.1.1. Frequency analysis results 27

3.2.2.1.2. Winner-Loser, Money-Time Table 28

$\begin{array}{lll}3.2 .2 .2 . & \text { District } 2 & 31\end{array}$

3.2.2.2.1. Frequency analysis results 31

3.2.2.2.2. Winner-Loser, Money-Time Table 31

$\begin{array}{lll}\text { 3.2.2.3. District } 3 & 34\end{array}$

3.2.2.3.1. Frequency analysis results 34

3.2.2.3.2. Winner-Loser, Money-Time Table 34 
3.2.2.4. District $4 \quad 37$

3.2.2.4.1. Frequency analysis results 37

3.2.2.4.2. Winner-Loser, Money-Time Table 37

3.2.2.5. District 5 40

3.2.2.5.1. Frequency analysis results 40

3.2.2.5.2. Winner-Loser, Money-Time Table 40

3.2.2.6. District $6 \quad 43$

3.2.2.6.1. Frequency analysis results 43

3.2.2.6.2. Winner-Loser, Money-Time Table 43

3.2.2.7. District $7 \quad 45$

3.2.2.7.1. Frequency analysis results 45

3.2.2.7.2. Winner-Loser, Money-Time Table 45

$\begin{array}{lll}3.2 .2 .8 . & \text { District } 8 & 48\end{array}$

3.2.2.8.1. Frequency analysis results 1

3.2.2.8.2. Winner-Loser, Money-Time Table 49

3.3. Results and Recommendation $\quad 50$

4. LESSONS LEARNED DOCUMENT

4.1. Introduction $\quad 52$

4.2. Project Stages 53

4.2.1. Permit 53

4.2.2. Site Work $\quad 53$

4.2.3. Foundation 54

4.2.4. Construction $\quad 54$

4.2.5. Land Scaping $\quad 55$

4.2.6. Other 56

4.3. Lessons Learned $\quad 56$

4.3.1. Introduction $\quad 56$

4.3.2. Lessons Learned-PERMIT $\quad 57$

4.3.3. Lessons Learned-SITE WORK 58

4.3.4. Lessons Learned-FOUNDATION 59

4.3.5. Lessons Learned-CONSTRUCTION 62

4.3.6. Lessons Learned-LAND SCAPE 77

4.3.7. Lessons Learned-OTHER 79

4.4. Results and Recommendation 85

5. SUMMARY AND RECOMMENDATION 86

5.1. Introduction $\quad 86$

5.2. Summary $\quad 86$

5.3. Research Contributions 88

$\begin{array}{lr}\text { REFERENCES } & 89\end{array}$ 


\section{LIST OF TABLES}

TABLE

PAGE

1. Claim Resource Classification between 1991 and 1997

2. Number of Disputes in Each District

3. Number of Disputes Under General Characteristics

4. Analysis of Disputes Regarding Claimer and Winner 25

5. Analysis of Disputes Regarding Monetary and Time Value

6. Frequency Analysis Results for District 1

7. Winner-Loser, Money-time Results for District 1

8. Frequency Analysis Results for District 2

9. Winner-Loser, Money-time Results for District 2

10. Frequency Analysis Results for District 3

11. Winner-Loser, Money-time Results for District 3

12. Frequency Analysis Results for District 4

13. Winner-Loser, Money-time Results for District 4

14. Frequency Analysis Results for District 5

15. Winner-Loser, Money-time Results for District 5

16. Frequency Analysis Results for District 6

17. Winner-Loser, Money-time Results for District 6

18. Frequency Analysis Results for District 7

19. Winner-Loser, Money-time Results for District 7

20. Frequency Analysis Results for District 8

21. Winner-Loser, Money-time Results for District 8 
22. Number of Disputes for Permit Stage

23. Number of Disputes for Site Work Stage

24. Number of Disputes for Foundation Stage

25. Number of Disputes for Construction Stage 55

26. Number of Disputes for Land Scaping Stage 56

27. Number of Disputes for Other Stage 


\section{LIST OF FIGURES}

FIGURE

PAGE

1. Research Methodology Outline 3

2. Claim Resource Classification in year $1998 \quad 10$

3. Claim Resource Classification in between 2002 and 2006

4. Resources of Discrepancy in Contract Documents 12

5. Reasons for Disputes Regarding Payment 13

$\begin{array}{ll}\text { 6. DRB Process } & 16\end{array}$

7. Analysis of Disputes Regarding Monetary and Time Value 26

8. Money Claimed for District $1 \quad 30$

9. Time Claimed for District $1 \quad 30$

10. Time Claimed for District 2

11. Money Claimed for District 2

12. Time Claimed for District 3

13. Money Claimed for District $3 \quad 36$

14. Money Claimed for District 4

15. Time Claimed for District 4

16. Money Claimed for District 5

17. Time Claimed for District 5

18. Money Claimed for District $7 \quad 47$

19. Time Claimed for District $7 \quad 47$

20. Money Claimed for District $8 \quad 50$

21. Time Claimed for District 8 
23. Lessons Learned for Site Work

24. Lessons Learned for Foundation a

25. Lessons Learned for Foundation b

26. Lessons Learned for Foundation c

27. Lessons Learned for Construction a

28. Lessons Learned for Construction b 63

29. Lessons Learned for Construction c

30. Lessons Learned for Construction d 65

31. Lessons Learned for Construction e 66

32. Lessons Learned for Construction $\mathrm{f}$

33. Lessons Learned for Construction $g$ 68

34. Lessons Learned for Construction h

35. Lessons Learned for Construction i

36. Lessons Learned for Construction $\mathrm{j}$

37. Lessons Learned for Construction $\mathrm{k}$

38. Lessons Learned for Construction 1

39. Lessons Learned for Construction m

40. Lessons Learned for Construction n

41. Lessons Learned for Construction o

42. Lessons Learned for Land Scape a

43. Lessons Learned for Land Scape b

44. Lessons Learned for Land Scape c 
45. Lessons Learned for Other a

46. Lessons Learned for Other $b$

47. Lessons Learned for Other c

48. Lessons Learned for Other d

49. Lessons Learned for Other e

50. Lessons Learned for Other $\mathrm{f}$ 


\section{INTRODUCTION}

\subsection{Introduction}

Over the years the construction industry dealt with the resolution of claims and disputes because of the adversarial nature of this industry. R.B Hellard (1987), D.A Langford (1992), M. Smith (1992), and S.O. Cheung and C.H. Suen (2002) stated that disputes are inevitable in construction because schedule delays, material overruns, unexpected conditions can be the subject of costly and prolonged claims and litigation. These create some trouble for all parties to a construction project.

In transportation business, projects determine where people live and work and how communities evolve. Because of these impacts, great controversy exists around transportation policies and their implementation. Parties involved in the transportation business are finding themselves in need of better ways to identify preferred approaches to solving transportation problems.

\subsection{Problem Statement}

Dispute in construction industry might be coming in the form of financial, legal or any other. Wahi (2008) stated that disputes most often leads to problems, losses in terms of economic, time, market share and reputation. According to Groton (1997); Mitropoulos and Howell (2001) evidence showed that the amount of disputes on construction projects can be reduced through dispute identification.

Caldas, Gibson, Weerasooriya, and Yohe (2009) stated that repetitive mistakes on big projects are costly for the construction industry; on the contrary, the benefits of repeating the positive outcomes from previous cases are great. It is also stated that an 
effective lessons learned system is a great step in the management of knowledge and it will lead a great benefit in the competitive construction industry.

In the field of transportation, lessons learned can be applied at different points in a variety of ways. These processes are helpful for dealing with problems and issues at the local, regional, state, and national levels. They can be used throughout the entire sequence of transportation decision making, from transportation planning to project development.

Lesson learned is well revered in its theoretical state; however, there is a serious disconnect when it comes to real-life application. Lessons learned are under-utilized within transportation industry or mistakenly applied. There are numerous problems faced by practitioners: Many of the available lessons learned (a) are theoretical in nature, (b) are not readily useable for construction applications, and (c) their reliability and benefits are not clear. Therefore, a close examination of the available statements/disputes at Dispute Resolution Board (DRB) database is necessary to be adjusted to help the industry to benefit from past cases.

\subsection{Research Objective}

The purpose of this research is to identify, analyze and evaluate the current dispute reports in DRB database and develop a lessons learned document for FDOT.

\subsection{Research Methodology}

The flowchart shown in Figure 1.1 outlines the phases of this research. A detailed explanation for each phase is presented in the introduction section of its respected chapter. 


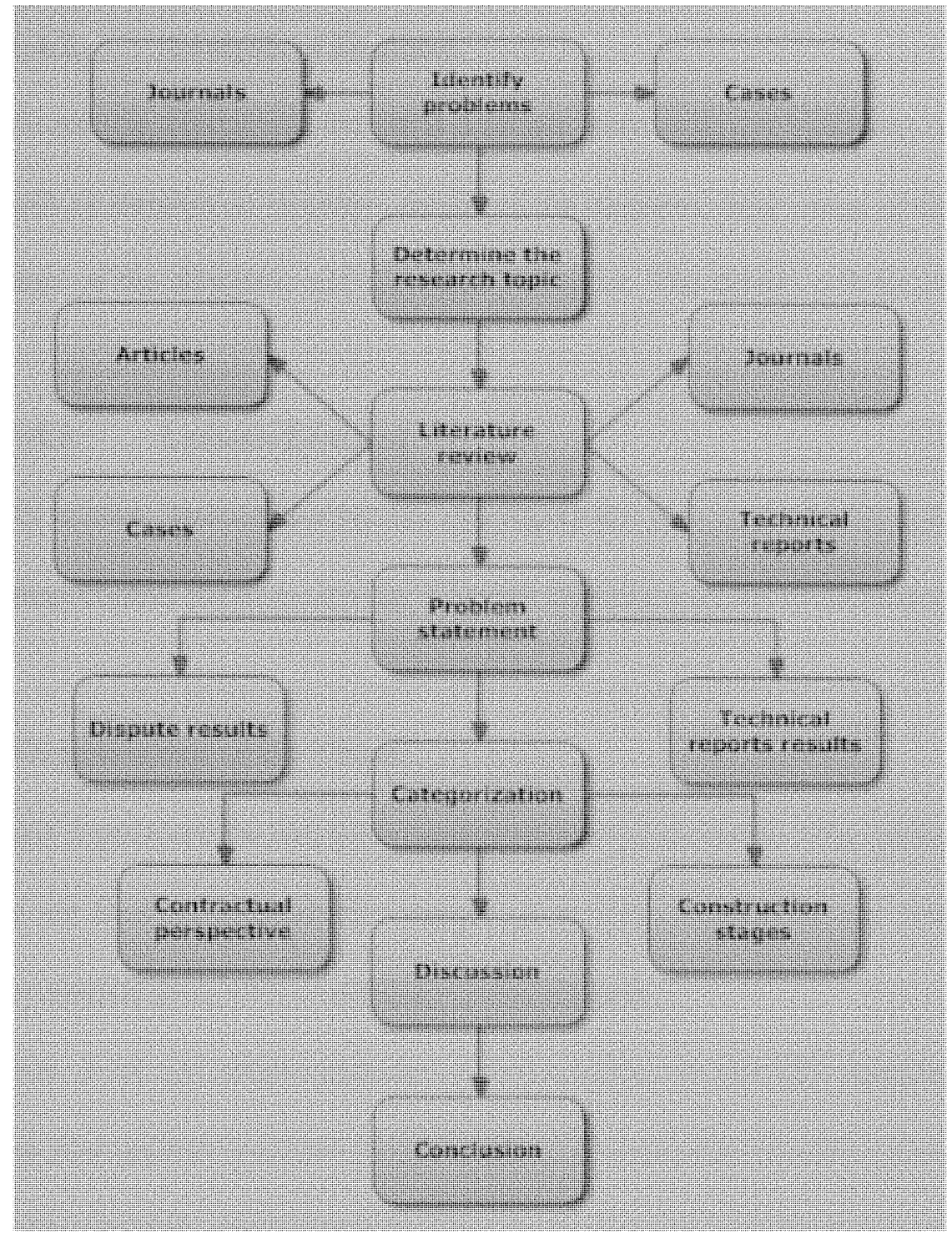

Figure 1: Research Methodology Outline

\subsubsection{Literature Review}

The first phase of the research methodology included a thorough literature review on disputes and lessons learned. The following resource mediums were used to perform the literature review: academic journals, technical reports, news articles, and online resources. 


\subsubsection{Analysis of Disputes}

In this section, disputes in the DRB database were analyzed by taking into account the topics such as number of disputes, origin of the disputes, time value of the disputes, monetary value of the disputes, and the results of them. The details will be explained in chapter 3 .

\subsubsection{Lessons Learned}

In this section, lessons learned are developed for each problem that may come up in every transportation projects during. Lessons learned will be explained in detail in chapter 4.

\subsection{Organization of the Thesis}

Chapter 2 presents the literature conducted for this research. This section includes an overview on lessons learned, the impact of lessons learned on the transportation projects. The section ends with a summary of the chapter.

Chapter 3 of the thesis provides categorization of the 262 disputes in DRB database. The first section provides introduction to 262 disputes of DRB cases. The next section provides the first categorization developed about lessons learned by considering contractual documents. The next section explores the modification to first categorization due to being still not user friendly. The next two sections provide the similar studies done in the previous two sections selecting a different perspective; project stages in transportation projects. The last section of the chapter provides a summary for the results.

The focus of Chapter 4 is the lessons learned. The first section is an introduction that provides an overview of lessons learned. The next section provides a detailed account of how the lessons learned were created. The majority of the chapter consists of the 
lessons learned and the different elements associated with it. The last section in this chapter is a summary of the results.

Chapter 5 presents a summary of the thesis and a summary of the results. It presents the research contribution to the body of knowledge, provides limitations of the research and then ends with future research possibilities. 


\section{LITERATURE REVIEW}

\subsection{Introduction}

H.S Richard (2002) mentioned that the construction business has recently appeared to be one of the most prone to problems and opposing ideas with disputes on construction projects. Schedule delays, material overruns, unexpected conditions can be the subject of expensive and protracted claims and litigation, and create serious risks for all parties to a construction project.

The first task in this research was to conduct a thorough literature review. The objectives of this literature review were to provide an overview of disputes, lessons learned, DRB concept, and solutions applied so far in decision making process of transportation business. Moreover, it targets to focus on evaluation of the impact that lessons learned have on decision making process. The following resources were used to achieve the presented objectives: academic journals, technical reports, news articles, and online resources.

\subsection{Definition of Disputes}

In the Longman dictionary dispute is defined as a serious argument or disagreement between two parties, either contractual or non contractual. In dictionary of law dispute is defined as a conflict of claims or rights. Dispute appears when one of the parties requests something from the other ones by referring to their contract and the request is not resolved.

Hibberd, Newman (1999) explained that a dispute takes place if there is a certain dissimilarity of opinion regarding the understanding and application of the contract. 
In summary, disputes in a simplest way in principle is that it is a disagreement between groups of people of which either one or both of the parties involved in an agreement did not success to deliver the agreed work. The more detailed information about the disputes will be provided in the next chapter.

The strategy that will be used to categorize the disputes focuses on the primary knowledge of memory of stored cases recording specific prior cases. In addition to this, as Ernst and Young (2006) clarified in the survey that $91 \%$ believed that lessons learned on projects are critical, remembering what has been learned so far both from mistakes and successes will prevent the industry from repeating mistakes. The method is based on two principles. First, the world is regular: similar problems have similar solutions. Consequently, solutions for similar problems are a useful starting point for other cases. Second, the types of the problems an engineer encounters tend to recur. Therefore, future cases are likely to be similar to current cases. When the two principles hold, it is worth to remember and reuse current reasoning (Leake 1996).

In Case Based Reasoning (CBR), tasks are often divided into two classes, interpretive CBR and problem-solving CBR (e.g., Kolodner, 1993; Rissland, Kolodner, \& Waltz, 1989). Interpretive CBR uses prior cases as reference point to classify or characterize new cases. The second class; problem solving CBR uses prior cases to suggest solutions that might be implement to new cases. Since each claim case is unique, prior cases will be used to form a judgment about or classification of a new case, by comparing and contrasting it with new cases that have already been classified (Ashley \& Rissland, 1987). Also, Ashley (1990), Bain (1989), Branting (1991), Cuthill (1992) and Sanders (1994) stated that interpretive CBR played a fundamental role in interpreting 
legal concepts. The method held in this research is similar to interpretive CBR. Basically, interpretive CBR consists of four steps.

First, the reasoner must perform situation assessment (Kolodner 1993; Owens 1991), to determine which features of the current situation are really relevant. In order to do that, it is necessary to categorize claims in the DRB database in an orderly manner.

Concerning the category for claim source classification there are many studies conducted on different topics; claim nature analysis and industrial experiences, court cases, contractual documents. Fenn et al (1997) summarized these research efforts conducted by some authors between the years 1991 and 1997 in construction business in the following table on the next page: 


\begin{tabular}{|c|c|}
\hline Research Author & Sources of Conflicts and Disputes in Construction \\
\hline Hewit (1991) & $\begin{array}{l}\text { 1) change of scope } \\
\text { 2)change conditions } \\
\text { 3)delay } \\
\text { 4)disruption } \\
\text { 5) acceleration } \\
\text { 6) termination } \\
\end{array}$ \\
\hline Watts and Scrivener (1993) & $\begin{array}{l}\text { 1) determination of agreement } \\
\text { 2) payment related } \\
\text { 3) site and execution of work } \\
\text { 4)time related } \\
\text { 5) final certificate } \\
\text { 6) tort }\end{array}$ \\
\hline Rhys Jones (1994) & $\begin{array}{l}\text { 1) management } \\
\text { 2) culture } \\
\text { 3) communication } \\
\text { 4) design; } \\
\text { 5) economics; } \\
\text { 6) tendering pressures } \\
\text { 7) law } \\
\text { 8) unrealistic expectations } \\
\text { 9) contracts } \\
\text { 10) workmanship } \\
\end{array}$ \\
\hline Heath et al. (1994) & $\begin{array}{l}\text { 1) contract terms } \\
\text { 2) payment } \\
\text { 3) variations } \\
\text { 4) time } \\
\text { 5) nomination } \\
\text { 6) renomination } \\
\text { 7) information. } \\
\end{array}$ \\
\hline Sykes (1996) & $\begin{array}{l}\text { 1) misunderstandings } \\
\text { 2) unpredictability }\end{array}$ \\
\hline Semple et al. (1996) & $\begin{array}{l}\text { 1) acceleration } \\
\text { 2) access } \\
\text { 3) weather } \\
\text { 4) changes }\end{array}$ \\
\hline Conlin et al. (1996) & $\begin{array}{l}\text { 1) payment } \\
\text { 2) performance } \\
\text { 3) delay } \\
\text { 4)negligence } \\
\text { 5) quality } \\
\text { 6) administration. }\end{array}$ \\
\hline
\end{tabular}

Table 1: Claim Resource Classification between 1991 and 1997 
After 1997, Kumaraswamy and Yogeswaran (1998), Yate (1998) and Bristow (1998) indicated the reasons of the construction disputes in the following figure:

\section{IMPORTANT REASONS FOR DISPUTES}

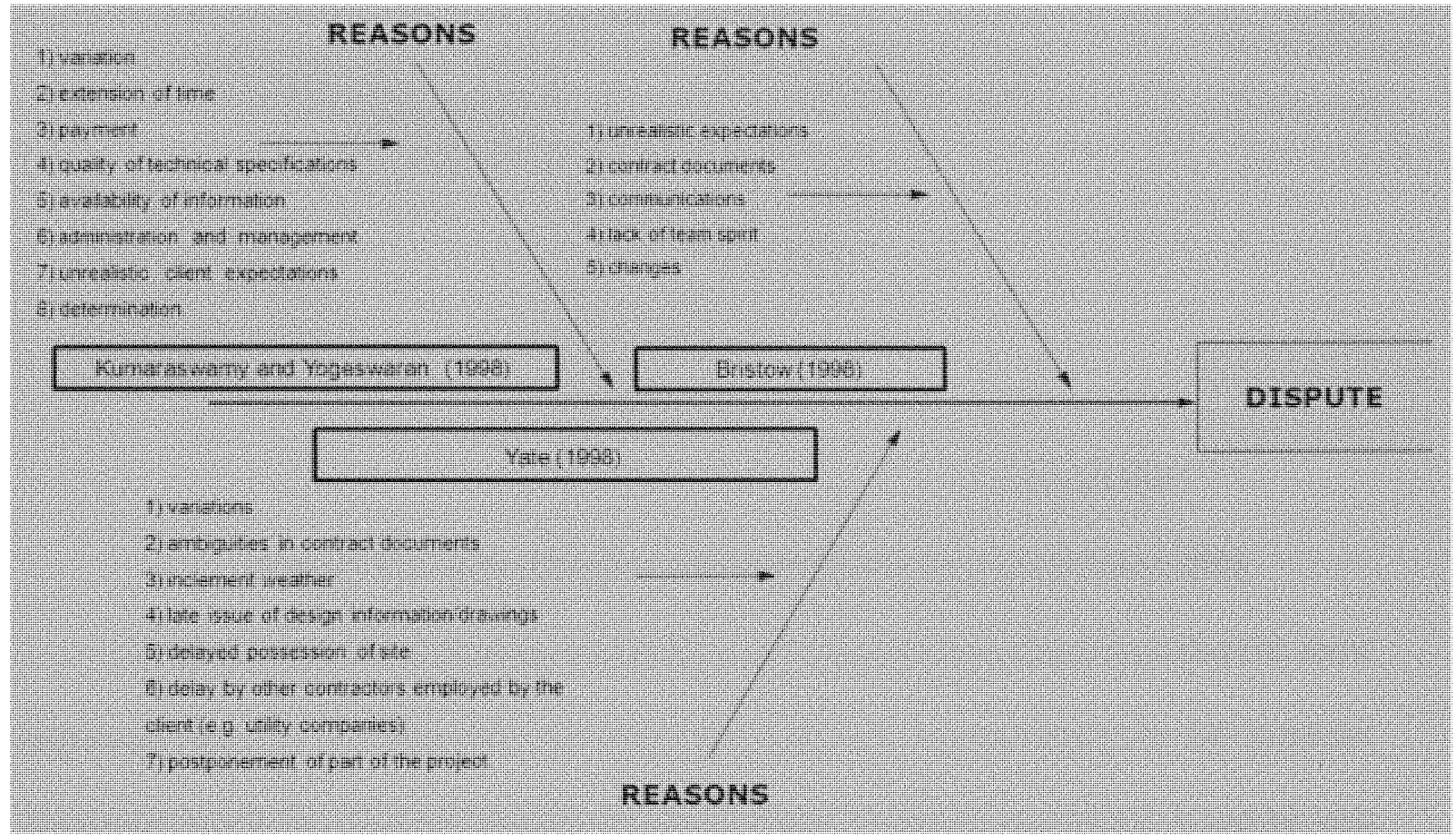

Figure 2: Claim Resource Classification in year 1998

From 2002 to 2006 several researches were conducted to classify the factors that drive the development of the disputes. The following table illustrates these studies: 


\section{IMPORTANT REASONS FOR DISPUTES}

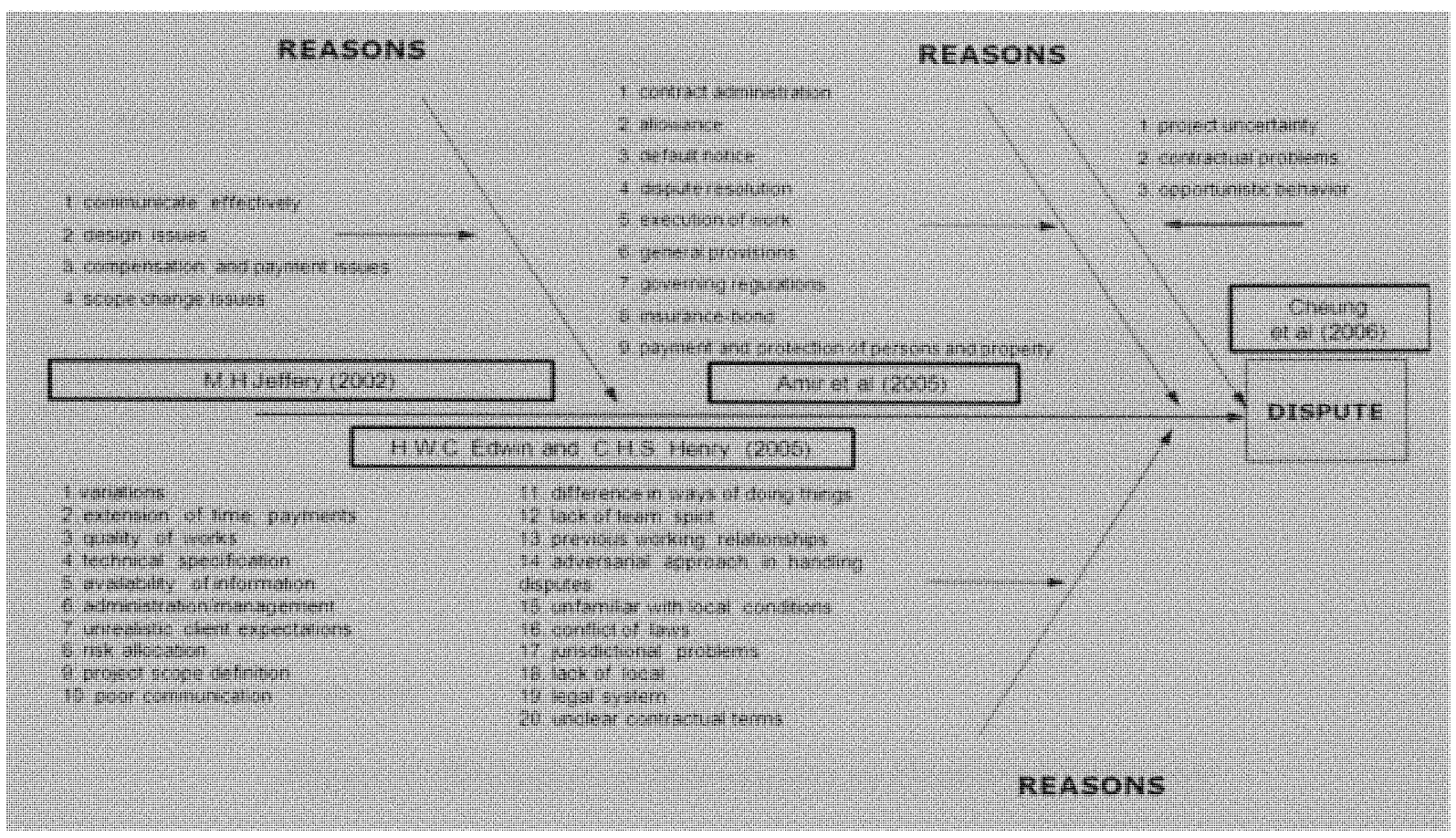

Figure 3: Claim Resource Classification between 2002 and 2006

In addition to those reasons for dispute, some researchers pinpointed that the most important reasons for disputes are observed from the inconsistency in the contract document. Each has different reasons for this dispute, however, in general, it can be said that these group of researchers defend the idea that inconsistencies often are the cause of disputes since each party will favor the interpretation that better suits his or her position. The following table shows the reasons of different researchers for this dispute. 


\section{DISCREPANCY IN CONTRACT DOCUMENTS}

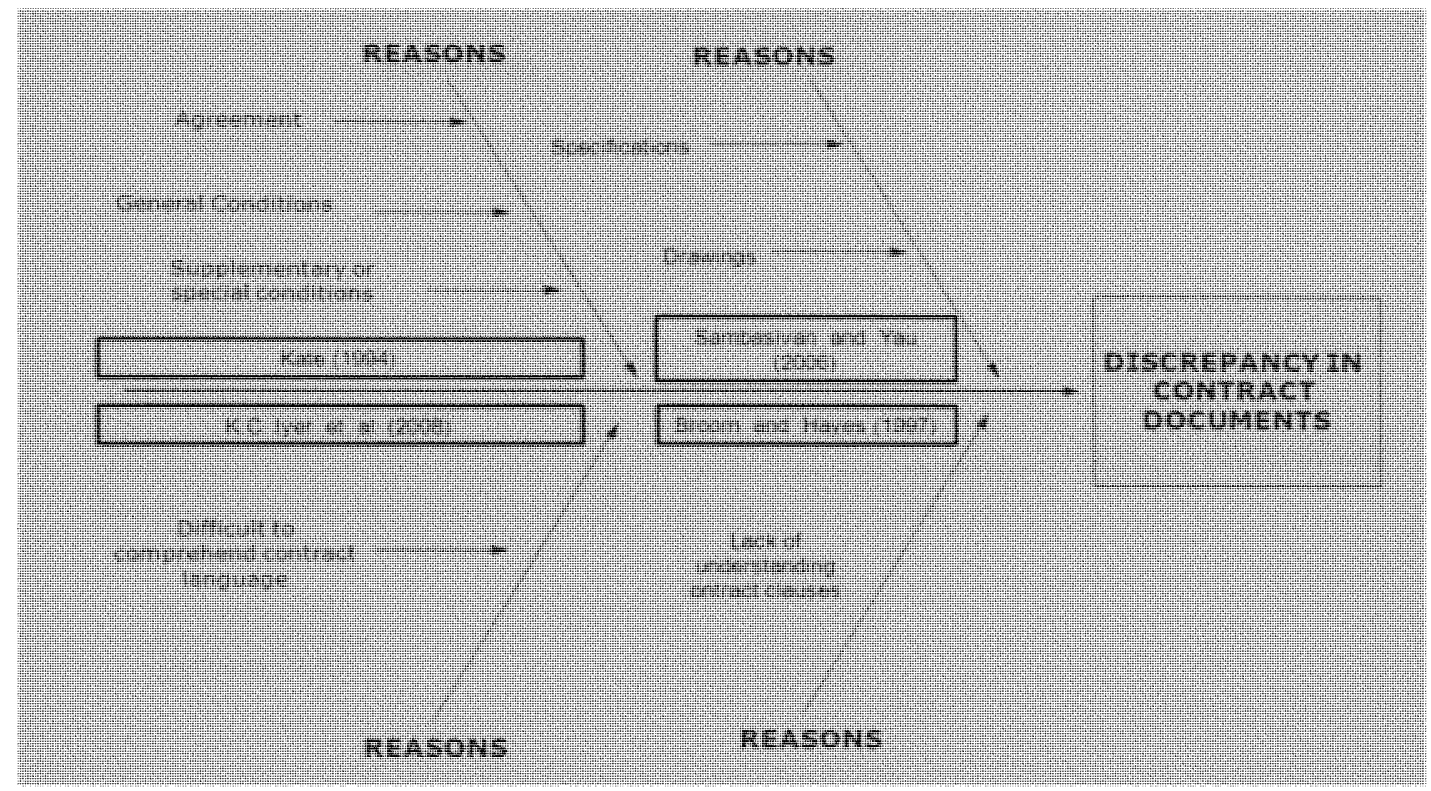

Figure 4: Resources of Discrepancy in Contract Documents

Moreover, Ameer Ali (2005) stated that payment is the lifeblood of the construction projects. The reason for this is because construction projects require a lot of money to be done. In addition to Ameer Ali (2005), Murdoch J and Hughes (2000) stated undoubtedly the most important of all obligations is to pay the Contract Sum. In the following figure, the researchers and their reasons for this payment issue is illustrated. 
IMPORTANT REASONS FOR DISPUTES REGARDING

PAYMENT

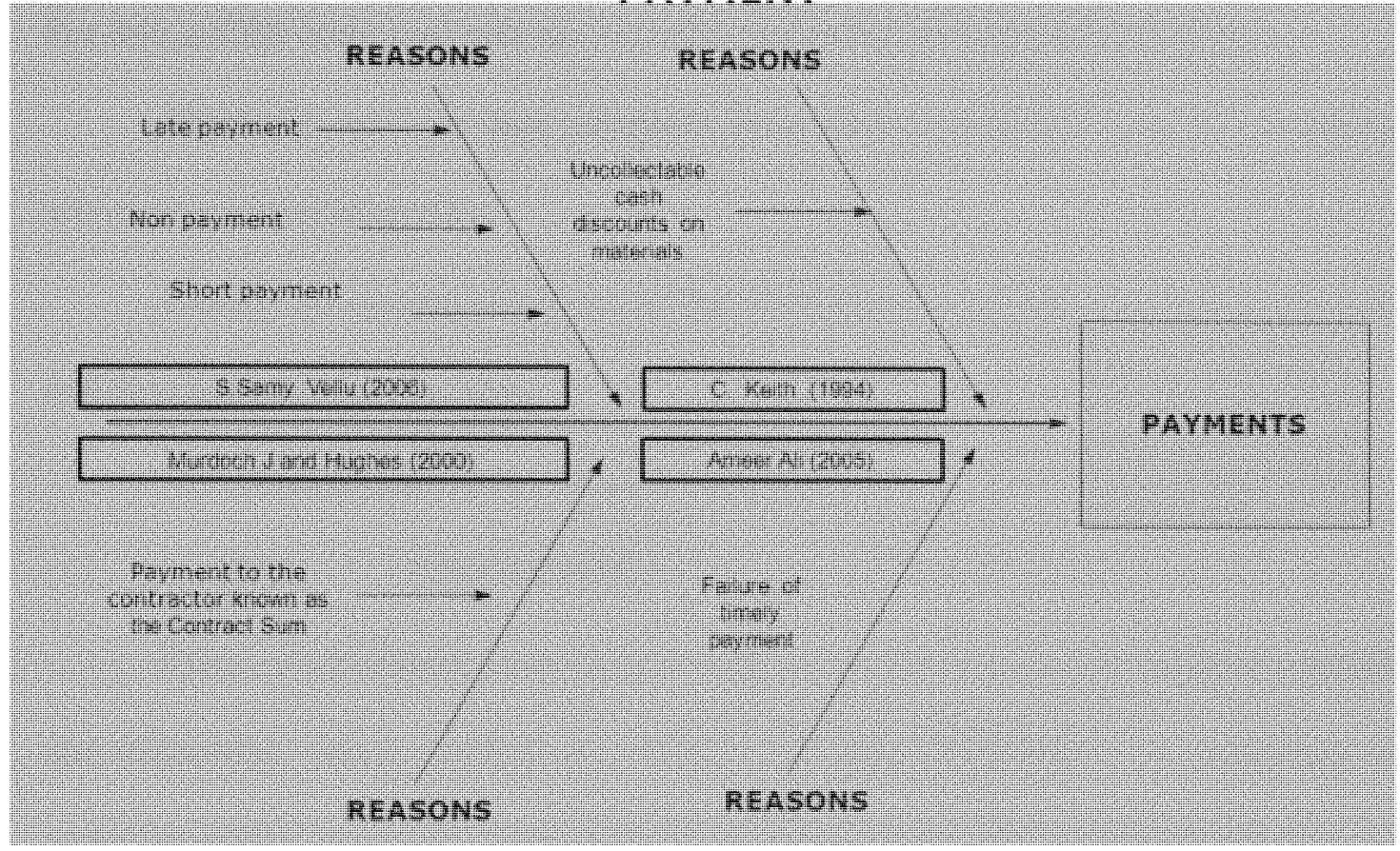

Figure 5: Reasons for Disputes Regarding Payment

Another important item for construction disputes is named as variation. At the time of tender, the design of the project is rarely completed in detail because; it is highly possible to have some changes during the construction. Therefore, items in the contractual documents may be changed means that the design team may not be required to complete their design until a very late phase. K.S Harban Singh (2003) pinpointed that result of such changes both in terms of the financial and the legal aspects can be a major basis of disagreement between the contracting parties.

The second step of CBR is based on the results of situation assessment; the reasoner retrieves a relevant prior case or prior cases. For this step, it should be verified that all cases in the database are included in the CBR system (collectively exhaustive) and each case is to be placed under a specific category (i.e.: stages of construction; foundation 
etc.) so all new cases can be compared and most relevant one can be retrieved efficiently. For this, a CBR technique will be used after reviewing all available techniques.

Third, the reasoner then compares those cases to the new situation, to determine which interpretation applies.

Finally, the current situation and the interpretation are then saved as a new case on which to base future reasoning.

\subsection{Dispute Resolution Board Concept}

\subsubsection{What is DRB?}

CEOs of profitable construction projects resolve claims and disputes adequately and efficiently. Some participants having the right combination of leadership skills, technical ability, business shrewdness, and interpersonal skills to resolve disputes among themselves take place in some number of projects. Other projects are cursed with problems and claims which are unfriendly and complicated to resolve. Most projects are in these two extremes. Owners beginning a construction project need to develop a technique for resolving the range of claims they might confront during the execution of a project. One of the most effective ways is the DRB. The DRB is a panel of three impartial reviewers formed at the beginning of the project to monitor the progress in the construction site, support to avoid disputes, and help to find solution of the disputes during the execution of the project.

The board provides the parties with a fair environment and an enlightened and rational basis for finding a solution for their disputes. The Board has knowledge and experience with (1) the design and construction steps pertaining to the project, (2) the construction ways and means used on the project, (3) the analysis and application of the 
contract documents, and (4) other processes of dispute resolution. Since DRB recommendations are non-bonding, the parties remain in control of the ultimate decision.

\subsubsection{How does DRB work?}

The Board is formed before site work commences and meets at the jobsite periodically. One of the three impartial professionals is selected by the owner with the confirmation of the contractor, one of them is selected by the contractor with the confirmation of the owner and the last one is selected with the agreed decision of the both the contractor and the owner. The board chooses one as chair with the approval of the contractor and the owner. The contract documents are given to the board in order to make the board familiar with the procedures of the project. The board meets with owner and contractor representatives during regular site visits and encourages the resolution of disputes at the job level. The three professionals in the board help the parties prevent disputes before they lead to major problems.

When a solution cannot be found by the parties for a dispute falling from the job site or the contract, the case can be transferred to the DRB. By the time the DRB comes up with a recommendation, it reviews the hearings received from the parties at which each party explains its position for the case. In arriving at a recommendation, the DRB considers the relevant contract documents, correspondence, other documentation, and the particular circumstances of the dispute. 


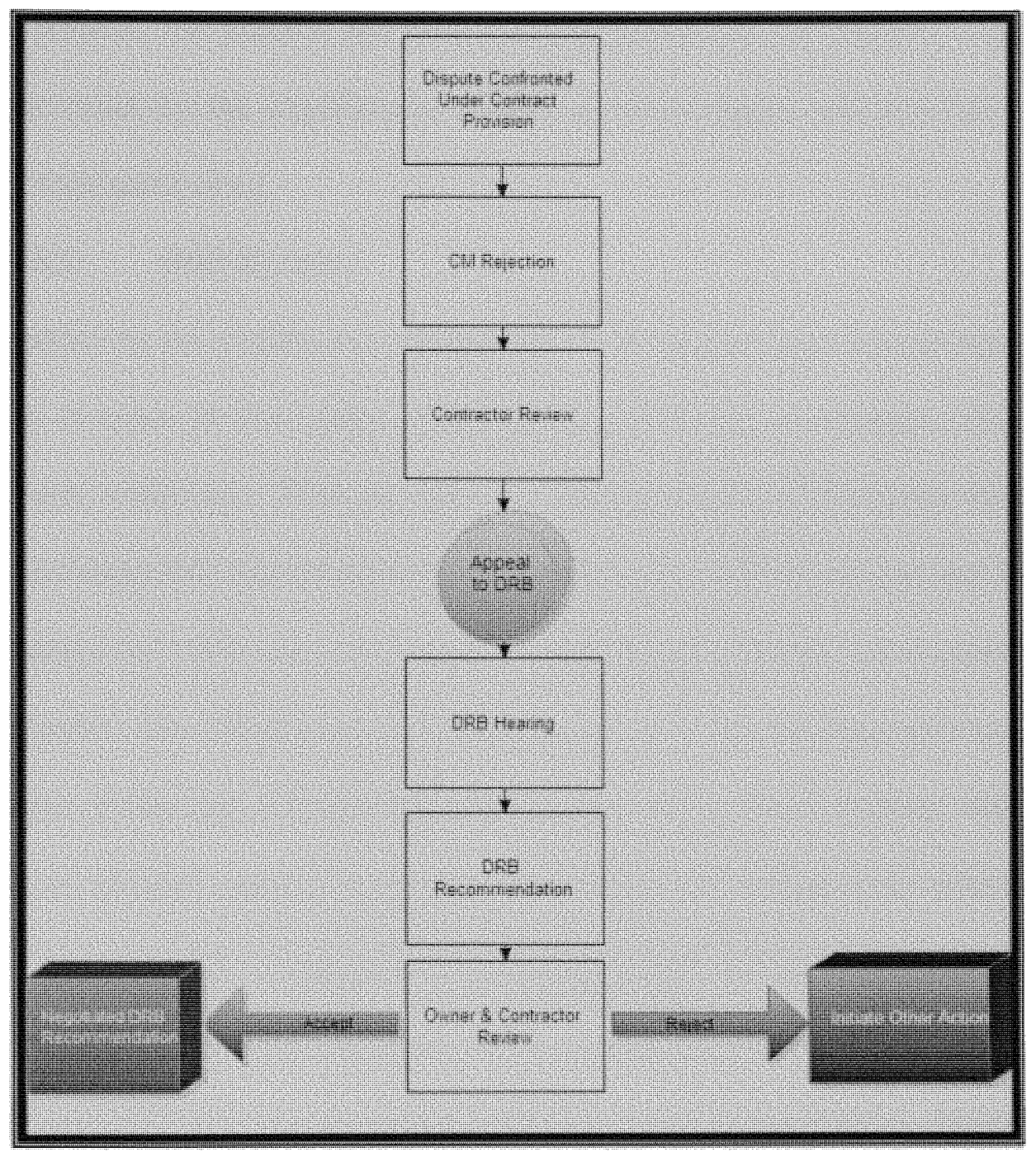

Figure 6: DRB Process

The result includes a written, non-binding recommendation for resolution of the dispute. The DRB report consists of an explanation of the Board's evaluation of the facts, contract provisions and the reasons that led to its conclusion. Depending on the confidence in DRB member`s technical knowledge, earliest understanding of the project conditions, and practical judgment; as well as by the parties opportunity to be heard, acceptance or denial of the recommendation can be observed. Although the board recommendation for resolution of a dispute is non-binding excluding the incentive and 
disincentive projects, the DRB is the most effective process if the contract language includes a provision for the eligibility of a DRB recommendation into any following arbitration or legal proceeding.

\subsubsection{DRB Benefits}

All parties on the construction project and to the project itself benefit from the DRB process in terms of both claim avoidance and resolution of disputes. The first benefit is claim avoidance. With the help of selected three professionals that are technically knowledgeable and experienced, the job site is monitored regularly and incase of a disagreement, the DRB team can handle the problem just in time before something serious takes place. The readily accessible dispute resolution process that uses a team of equally chosen, technically well-informed and skilled professionals familiar with the project tends to promote agreement on problems that would otherwise be referred to arbitration or litigation after a long and harsh period of posturing. It is established that the DRB process creates positive relations, open communication, and the trust and collaboration that is essential for the parties to resolve troubles harmoniously. Quite a lot of reasons for this consequence are, counting: (1) the parties are unwilling to posture by taking tenuous or extreme positions, since they do not want to lose their trustworthiness with the DRB members and (2) since the Board encourages the punctual recommendation of disputes and handles disputes on an personal basis, the collection of claims is minimized, therefore avoiding accumulation of unresolved claims that can generate an ambiance which fosters acrimony.

The second benefit is that the Board encourages the parties to resolve claims and disputes without delay, professional way. The Board members request for the possible 
problems and the status report of claims during the meetings held periodically. The Board encourages the parties to center on early identification and resolution of problems. Many cases illustrated that the parties resolve the problems and disputes by referring to the Board in an informal way.

It is found that the DRB process is more successful than any other technique of alternative dispute resolution for construction disputes. Success rate is very high ( $98 \%$ until 2007) in resolving disputes without appealing to litigation (DRB Manual, 2007). There are numerous factors for this statistic. First, the Board consists of members having knowledge and experience with (a) relevant design and construction processes to the project, (b) means and methods engaged on the project, (c) the appliance of contract documents, and (d) additional processes of dispute resolution. Since recommendation of the Board is non-binding excluding incentive and disincentive projects, the parties stay in control of the final decision. Next, when compared with the other dispute resolution techniques such as litigation and arbitration, the DRB process is extremely cheap. Next, The Board addresses the disputes as soon as a deadlock appears between the parties. Early resolution of disputes permits the parties to avoid the high expense and unpredictability of post project litigation. In addition to this, owners and contractors will avoid unproductive moments in the project lifecycle. While other methods for resolving disputes exist, none of them have the advantage of independent, knowledgeable professionals who visit the site during performance of the project.

\subsubsection{DRB Limitations}

Sometimes, there are some restrictions for the Board to control technical issues as different from matters requiring the application or understanding of the general and 
supplementary items and special provisions of the contract. The DRB team can deal with all problems if they are allowed to do so in the contract. In other words, the team can not go beyond the contract provisions.

\subsection{Lessons Learned}

\subsubsection{What are Lessons Learned?}

Throughout the construction of any facility knowledge is obtained and lessons are learned both from positive experiences and negative experiences through several resources; passive collection, reactive collection, after action collection, action collection, anonymous collection etc. As time passes, those people involved in construction life cycle have the chance to collect a plenty of knowledge, some of which is hardly gained. Purpose of using lessons learned is to support promoting recurrence of successful outcomes, and precluding the recurrence of unsuccessful outcomes. However, how many of these lessons, learned at great human or financial cost, are transferred in between projects and in between persons? Unluckily, very few organizations can claim they have an effective Lessons Learned process that spans their global project operations. Survey done by Ernst and Young (2006) revealed that, although 91\% of the respondents believed Lessons Learned reviews on projects were important, only $13 \%$ said their organizations performed them on all projects and only $8 \%$ believed the primary objective of the reviews was to understand the benefits that would accrue to the organization.

\subsubsection{Lessons Learned Barriers}

In the field of transportation, the lessons learned from claims are kept in DRB database. The application of lessons learned gained from previous cases to other/new cases is rare, supporting the survey results conducted by Ernst and Young (2006). It can 
be seen that, there are some barriers that prevent effective implementation of lessons learned. These barriers are: (i) too general to be passed from one case to another, (ii) ambiguous, not mutually exclusive and collectively exhaustive to implement, (iii) not typically linked to project stage, (iv) lacking of a meaningful classification system, (v) difficulty in integrating new systems into existing procedures and operations, (vi) unmanageable format that limits access, retrieval, and updating of the potentially enormous volume of lessons etc. (Marlin, 2008).

\subsubsection{Lessons Learned Benefits}

To overcome these problems mentioned in the barriers part, traditional (existing) methods to implement lessons learned to projects will be edited to help the industry benefit from them more effectively. Spilsbury, Perch, Norgbey, Rauniyar, and Battaglino (2007) stated that lessons learned provide many benefits if used effectively. These benefits can be mentioned as follows; lessons learned allow other practitioners to learn from previous experience and avoid reinventing the wheel. They help stakeholders at different levels understand the relevance of other activities, and achievements, thus improving collaboration and co-ordination. Moreover, lessons inform decision-makers to help avoid common mistakes and help promote a more enabling environment.

\subsubsection{Review of Lessons Learned}

Professional evaluators in United Nations Environmental Programme (UNEP, January, 2007) developed 'minimum quality criteria' for evaluation of lessons. A quality lesson must concisely capture the context from which it is derived, must be applicable in a different context (generic), have a clear 'application domain'. 
Approximately two hundred and sixty two reports from DRB database produced between 1994 and 2008 were reviewed against the above criteria. The main aim while developing lessons is to match these cretieria. This categorization will be explanied in the next chapter.

\subsubsection{Who Are the Users of Lessons Learned?}

The lessons learned targets a wide range of users. From automotive industry, to marketing, from construction industry to agriculture industry, lessons can be learned from the large-scale marshalling of people both from positive or negative moments. The lessons learned collected from the diverse perspectives of different projects can help the parties to promote the recurrence of successful outcomes and preclude the recurrence of unsuccessful outcomes in the future.

\subsection{Parties: Florida Department of Transportation (FDOT) and The Contractor}

Fenn et al. (1997) stated that for years there are disagreements between the owners and the contractors. For transportation business in Florida, for government projects Florida Department of Transportation (FDOT) is the owner. The Florida Department of Transportation is established to serve the Florida state of United States by guaranteeing a fast, safe, efficient, accessible and convenient transportation system that meets critical national interests and improves the quality of life of the people. With the responsibility for shaping and administering policies and programs to protect and improve the safety, suitability, and efficiency of the transportation system and services, FDOT is one of the capital agencies in the federal government. 
Predictably, each party's priorities are at conflict with the others, establishing a recurring cycle of fighting. Howard et al. (1997) stated the differences in between the parties. In owner's perspective, the aim in the project is to obtain maximum quality, functionality and capacity while keeping the cost at minimum. On the contractor's side, the purposes are to build up a satisfied client, to achieve financial goals in long run which can be established by keeping the resources used in the site minimum to meet the minimum required scope of work.

\subsection{Summary}

The literature review provided the basics for understanding the rest of the thesis content. The review covered the following areas: overview of disputes, lessons learned, dispute resolution board (DRB) and the parties involved in the project. The following resources were used to achieve the presented objectives: academic journals, technical reports, news articles, and online resources.

Two facts that form the basis of the thesis were revealed after completing the literature review: the lack of organization of the disputes, related reasons and results causes inefficient use of lessons learned from these experiences in construction industry. In addition to this, a research about lessons learned especially in transportation projects has not been studied yet. The state-of-practice of lessons learned usage in the transportation business is needed. There were two major shortcomings with this research as it related to construction practitioners: 1) the categorization of disputes did not have a certain form for users to place the new cases in future and 2) the lessons learned were not studied to help the industry promote the recurrence of the successful outcomes and prohibit the unsuccessful outcomes. 


\section{DISPUTE CHARACTERISTICS}

\subsection{Introduction}

In this chapter, a detail analysis of 262 DRB disputes and results will be shown and elaborated by using frequency analysis, tables, and pie chart for each district. Data is analyzed and interpreted as presented to achieve the objectives of the study.

\subsection{Characteristics of Disputes}

\subsubsection{Data \& Information}

Relevant data and information are gathered to establish the connections between broad ranges of subjects in this research. DRB database is used to collect the relevant information for the disputes. In this section 262 disputes in DRB database will be analyzed. All disputes are issued by the contractors to DRB to be resolved except one. The following table illustrates the number of disputes coming from each dispute.

\begin{tabular}{|l|c|}
\hline & Number of Disputes \\
\hline District 1 & 75 \\
\hline District 2 & 14 \\
\hline District 3 & 8 \\
\hline District 4 & 19 \\
\hline District 5 & 40 \\
\hline District 6 & 2 \\
\hline District 7 & 58 \\
\hline District 8 & 46 \\
\hline
\end{tabular}

Table 2: Number of Disputes in Each District

As it can be seen from the table, District 1 has the most number of the disputes in the DRB data base with 75 disputes. The second one is District 7 and the third one is District 8 with the numbers 58 and 46 respectively. 
The subsequent table shows the number of disputes under general characteristics of material, quality, safety, plans \& specifications, construction methods, equipment, third party hindrance, quantity variation, unforeseen conditions and the permit issues.

\begin{tabular}{|l|c|}
\hline \multicolumn{1}{|c|}{ Characteristics } & Number of Disputes \\
\hline Material & 32 \\
\hline Quality & 3 \\
\hline Safety & 4 \\
\hline Plans \& Specifications & 43 \\
\hline Construction Methods & 22 \\
\hline Equipment & 2 \\
\hline Third Party Hindrance & 21 \\
\hline Quantity Variation & 58 \\
\hline Unforeseen Conditions & 67 \\
\hline Permit & 10 \\
\hline \multicolumn{2}{|r|}{ TOTAL } \\
\hline
\end{tabular}

Table 3: Number of Disputes under General Characteristics

FDOT (Owner) often tries to utilize construction contract language to assign responsibility for unforeseen conditions among themselves, contractors, and designers. However, here, it can be observed that sixty seven disputes $(\% 26)$ are under unforeseen conditions. Using the data from several recent studies, it is revealed that the actual contract language used is for the most part unrelated to the actual costs borne by FDOT and contractors. To avoid disputes related with unforeseen conditions, interpretive approach and early resolution of disputes are required (Halligan et al. 1987). To do so, lessons learned can be used to resolve similar disputes by comparing with the previous cases and results. The detailed information about unforeseen conditions and related lessons learned will be provided in the next chapter. Quantity variation is the second most encountered dispute characteristic with fifty eight disputes (\%22). The third dispute is plans and specifications with forty three disputes (\%16). 
In the following tables the analysis of the disputes are shown. The first analysis is based on the party that issued the case to DRB. As it can be seen from the table all disputes were issued to DRB by the contractors besides one. There was not a big gap between the parties that won the cases after DRB results. Out of 262 disputes, the contractors won 119 (\% 45.42) times while FDOT won $133(\%$ 50.76). In addition to these numbers, ten times (\% 3.82) the disputes were concluded in negotiation.

\begin{tabular}{|l|c|}
\hline \multicolumn{1}{|c|}{ Claimer } & 261 \\
\hline Contractor & 1 \\
\hline Owner/FDOT & \\
\hline
\end{tabular}

\begin{tabular}{|l|c|}
\hline \multicolumn{1}{|c|}{ Winner } & 119 \\
\hline Contractor & 133 \\
\hline Owner/FDOT & 10 \\
\hline Negotiate & 50.76336 \\
\hline of Winning (FDOT perspective) & 45.41985 \\
\hline$\%$ of Negotiation & 3.816794 \\
\hline
\end{tabular}

Table 4: Analysis of Disputes Regarding Claimer and Winner

In the next table the monetary value and time value of the disputes are shown. As it can be seen from the table, all disputes did not have a specified monetary value or time value on the dispute reports. Therefore, most of the disputes could not be analyzed for these aspects. The monetary value of the disputes revealed that 188 disputes (\%72) did not have any monetary specified. The remaining seventy four reports were placed under the ranges from $\$ 0-\$ 49,999$ to $\$ 150,000 \&$ above. On the other hand, the time value of the disputes shown that 185 disputes $(\% 71)$ did not have a specific time value. The remaining seventy seven disputes are located under the ranges from 0-25 days to 76 day $\&$ above. The results are as follows: 


\begin{tabular}{|l|c|}
\hline \multicolumn{2}{|c|}{ Monetary Value of Disputes } \\
\hline $0-\$ 49,999$ & 39 \\
\hline$\$ 50,000-\$ 99,999$ & 13 \\
\hline$\$ 100,000-\$ 149,000$ & 7 \\
\hline$\$ 150,000 \&$ above & 15 \\
\hline N/A & 188 \\
\hline
\end{tabular}

\begin{tabular}{|l|c|}
\hline \multicolumn{2}{|c|}{ Time Value of Disputes } \\
\hline $0-25$ days & 43 \\
\hline 26 days-50days & 9 \\
\hline 51 days-75 days & 12 \\
\hline 76 days \& above & 13 \\
\hline N/A & 185 \\
\hline
\end{tabular}

Table 5: Analysis of Disputes Regarding Monetary and Time Value

The next Venn diagram shows information about the disputes in terms of monetary and time values. The results are as follows:

\begin{tabular}{|c|c|c|c|c|}
\hline & Time & Money & Tinted Money & Tor Specified \\
\hline Sumber of Disputes & - & -1 & 51 & $16:$ \\
\hline
\end{tabular}

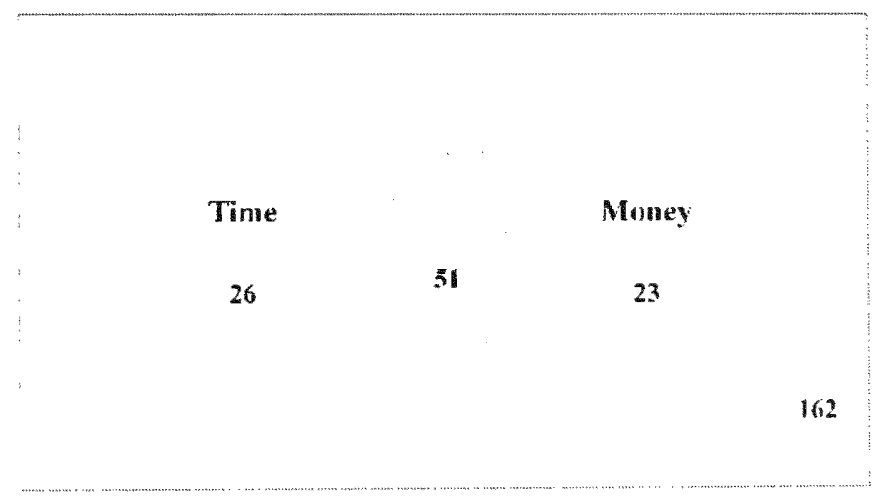

Figure 7: Analysis of Disputes Regarding Monetary and Time Value

\subsubsection{Data Analysis}

The data were categorized under different variables to represent the result of the research objectives. Analysis of data according to different objectives was done by statistical method; frequency analysis. For graphic result presentation, tables, and pie 
charts are used as summaries. In addition to this, money and time claimed in these disputes are studied and the results of these studies are provided in the pie-chart in the following pages.

\subsubsection{District 1}

This district consists of sixty six disputes. All of the disputes are numbered. This will help the user to find more detail in the dispute document for a desired type of dispute. Number fifty six and fifty seven are the expanded version of number fifty five. Therefore these two documents are excluded from district one so as not to be counted twice.

\subsection{Frequency analysis results}

Frequency analysis used a tabular form to represent the result of data analysis of frequency of each variable under categories. The result was tabulated in the form of frequency number and percentages according to total number of disputes. The following table illustrates the results of district \#1. 


\begin{tabular}{|l|c|r|}
\hline \multicolumn{1}{|c|}{ Characteristics } & Number & $\%$ \\
\hline Material & $\mathbf{3}$ & 4 \\
\hline Quality & & 0 \\
\hline Safety & & 0 \\
\hline $\begin{array}{l}\text { Plans \& } \\
\text { Specifications }\end{array}$ & 13 & 17.333 \\
\hline $\begin{array}{l}\text { Construction } \\
\text { Methods }\end{array}$ & 2 & 2.6667 \\
\hline Equipment & 1 & 1.3333 \\
\hline $\begin{array}{l}\text { Third Party } \\
\text { Hindrance }\end{array}$ & 10 & 13.333 \\
\hline Quantity Variation & 13 & 17.333 \\
\hline $\begin{array}{l}\text { Unforeseen } \\
\text { Conditions }\end{array}$ & 30 & 40 \\
\hline Permit & $\mathbf{3}$ & 4 \\
\hline TOTAL & $\mathbf{7 5}$ & $\mathbf{1 0 0}$ \\
\hline
\end{tabular}

Table 6: Frequency Analysis Result for District 1

\subsection{Winner-Loser, Money-Time Table}

The following table gives information about who opened the case, who won the case, what is the percentage rate of winning in this district. In what amount money and time the parties claimed, and finally it provides at what percentage the claimed time and money is won. 


\begin{tabular}{|l|c|}
\hline Claimer & \\
\hline Contractor & 75 \\
\hline Owner/FDOT & 0 \\
\hline
\end{tabular}

\begin{tabular}{|l|c|}
\hline Winner & \\
\hline Contractor & 43 \\
\hline Owner/FDOT & 32 \\
\hline & \\
\hline \% of Winning (FDOT perspective) & 42.6667 \\
\hline & 57.3333 \\
\hline
\end{tabular}

\begin{tabular}{|l|c|}
\hline \multicolumn{2}{|c|}{ Money Claimed } \\
\hline $0-\$ 49,999$ & 18 \\
\hline$\$ 50,000-\$ 99,999$ & 4 \\
\hline$\$ 100,000-\$ 149,000$ & 3 \\
\hline$\$ 150,000 \&$ above & 2 \\
\hline N/A & 48 \\
\hline
\end{tabular}

\begin{tabular}{|l|c|}
\hline \multicolumn{2}{|c|}{ Time Claimed } \\
\hline $0-25$ days & 18 \\
\hline 26days-50days & 3 \\
\hline 51days-75 days & 7 \\
\hline 76 days and above & 0 \\
\hline N/A & 47 \\
\hline
\end{tabular}

Table 7: Winner-Loser, Money-Time Results for District 1 


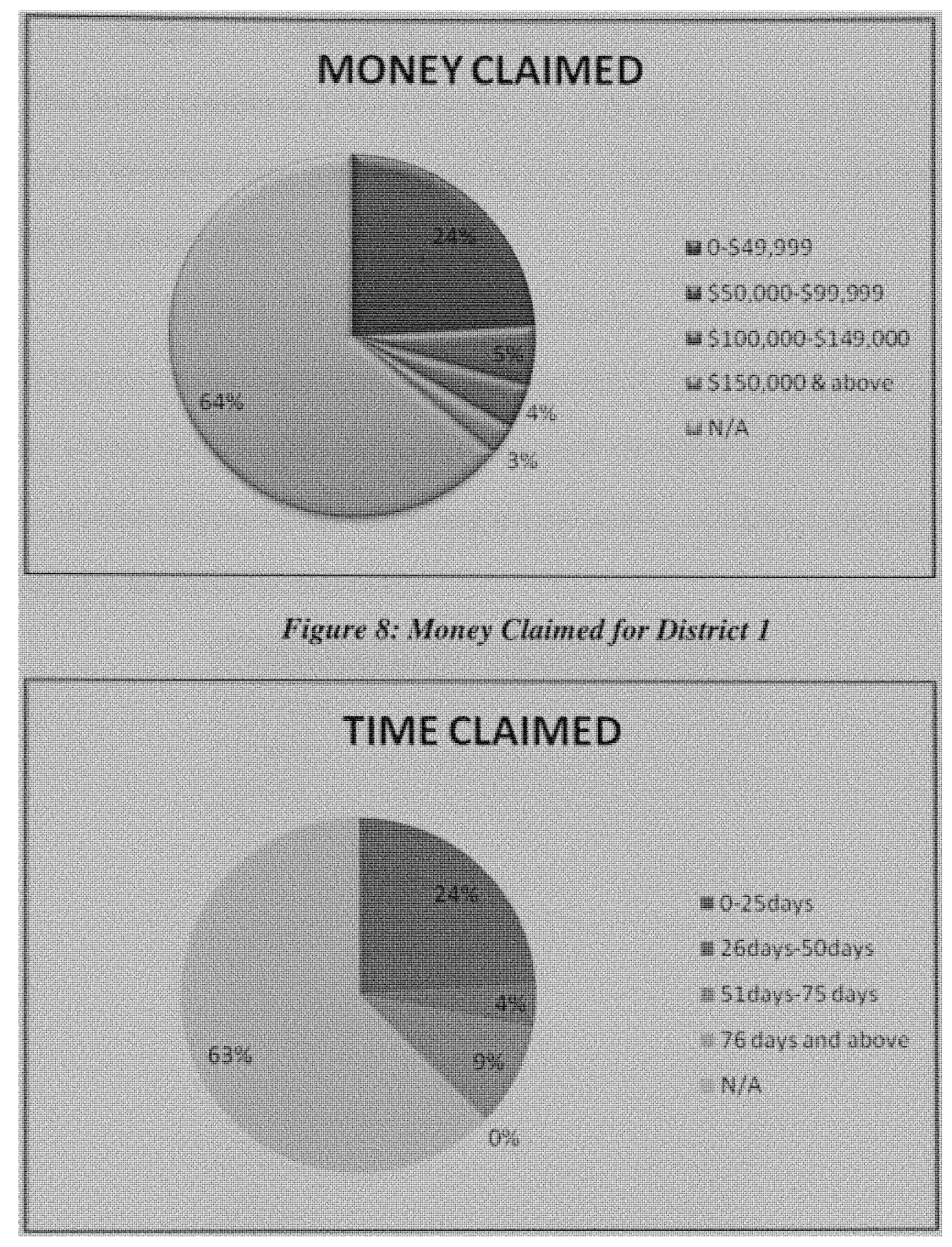

Figure 9: Time Claimed for District 1 


\subsubsection{District 2}

This district consists of thirteen disputes. All of the disputes are numbered starting from sixty six to seventy nine. This will help the user to find more detail in the dispute document for a desired type of dispute.

\subsection{Frequency analysis results}

Frequency analysis used a tabular form to represent the result of data analysis of frequency of each variable under categories. The result was tabulated in the form of frequency number and percentages according to total number of disputes. The following table illustrates the results of district \#2.

\begin{tabular}{|l|c|r|}
\hline \multicolumn{1}{|c|}{ Characteristics } & Number & \multicolumn{1}{c|}{$\%$} \\
\hline Material & $\mathbf{3}$ & 4 \\
\hline Quality & & 0 \\
\hline Safety & & 0 \\
\hline $\begin{array}{l}\text { Plans \& } \\
\text { Specifications }\end{array}$ & $\mathbf{1}$ & 1.3333 \\
\hline $\begin{array}{l}\text { Construction } \\
\text { Methods }\end{array}$ & $\mathbf{4}$ & 5.3333 \\
\hline Equipment & & 0 \\
\hline $\begin{array}{l}\text { Third Party } \\
\text { Hindrance }\end{array}$ & & 0 \\
\hline Quantity Variation & $\mathbf{4}$ & 5.3333 \\
\hline $\begin{array}{l}\text { Unforeseen } \\
\text { Conditions }\end{array}$ & $\mathbf{1}$ & 1.3333 \\
\hline Permit & $\boldsymbol{1}$ & $\mathbf{1 . 3 3 3 3}$ \\
\hline TOTAL & $\mathbf{1 4}$ & $\mathbf{1 8 . 6 7}$ \\
\hline
\end{tabular}

Table 8: Frequency Analysis Result for District 2

\subsection{Winner-Loser, Money-Time Table}

The following table gives information about who opened the case, who won the case, what is the percentage rate of winning in this district. In what amount money and 
time the parties claimed, and finally it provides at what percentage the claimed time and money is won.

\begin{tabular}{|l|c|}
\hline \multicolumn{1}{|c|}{ Claimer } & 14 \\
\hline Contractor & 0 \\
\hline Owner/FDOT & \\
\hline
\end{tabular}

\begin{tabular}{|l|c|}
\hline \multicolumn{1}{|c|}{ Winner } & 10 \\
\hline Contractor & 4 \\
\hline Owner/FDOT & \\
\hline & 28,57142857 \\
\hline & 71,42857143 \\
\hline
\end{tabular}

\begin{tabular}{|l|l|}
\hline \multicolumn{2}{|c|}{ Money Claimed } \\
\hline $0-\$ 49,999$ & 2 \\
\hline$\$ 50,000-\$ 99,999$ & 1 \\
\hline$\$ 100,000-\$ 149,000$ & 1 \\
\hline$\$ 150,000$ \& above & 1 \\
\hline N/A & 9 \\
\hline
\end{tabular}

\begin{tabular}{|l|c|}
\hline \multicolumn{2}{|c|}{ Time Claimed } \\
\hline $0-25$ days & 1 \\
\hline 26days-50days & 1 \\
\hline 51days-75 days & 1 \\
\hline 76 days and above & 0 \\
\hline N/A & 11 \\
\hline
\end{tabular}

Table 9: Winner-Loser, Money-Time Results for District 2 


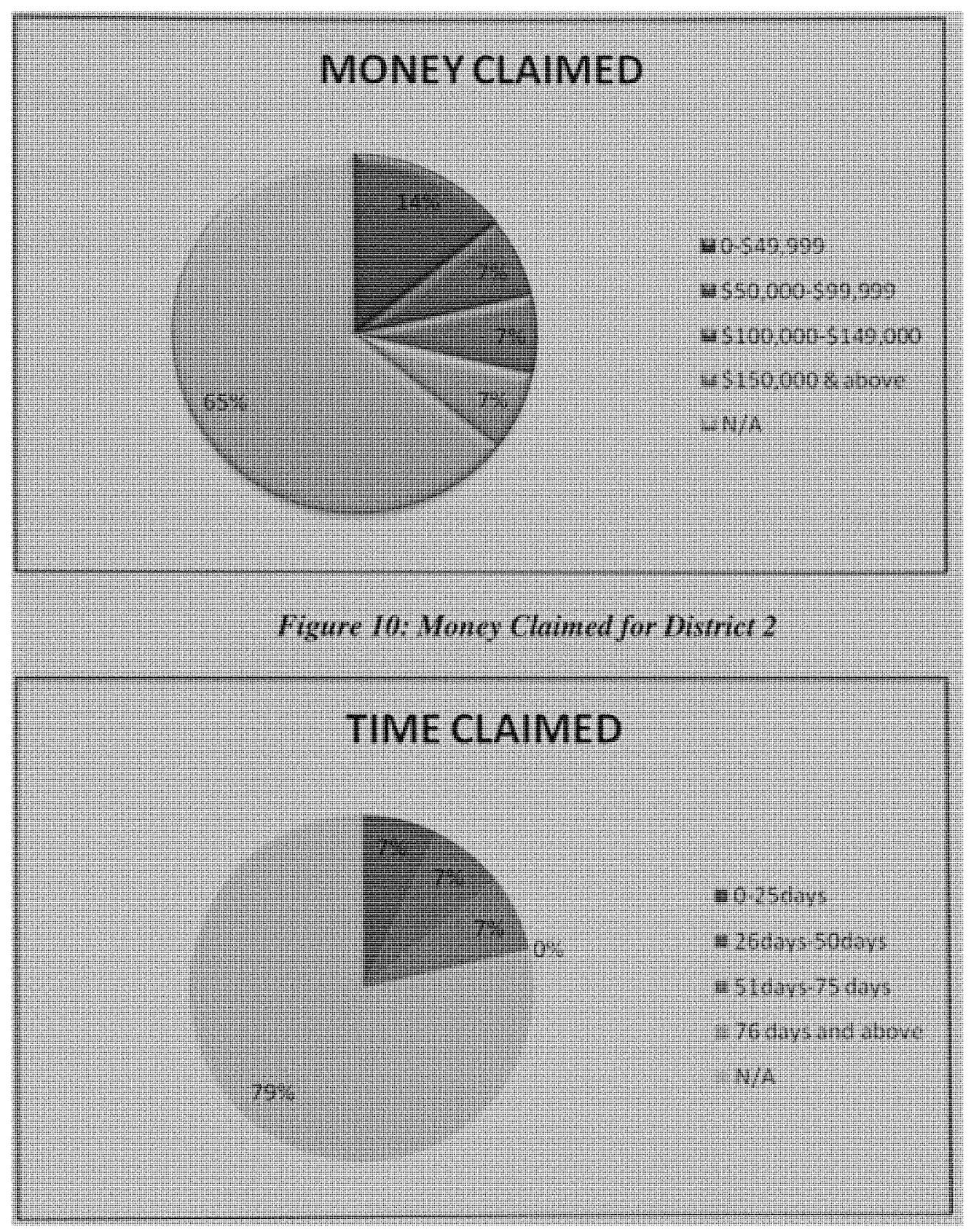

Figure 11: Time Claimed for District 2 


\subsubsection{District 3}

This district consists of eight disputes. All of the disputes are numbered starting from eighty to eighty seven. This will help the user to find more detail in the dispute document for a desired type of dispute.

\subsection{Frequency analysis results}

Frequency analysis used a tabular form to represent the result of data analysis of frequency of each variable under categories. The result was tabulated in the form of frequency number and percentages according to total number of disputes. The following table illustrates the results of district \#3.

\begin{tabular}{|l|c|r|}
\hline \multicolumn{1}{|c|}{ Characteristics } & Number & $\%$ \\
\hline Material & $\boldsymbol{1}$ & 12.5 \\
\hline Quality & & 0 \\
\hline Safety & & 0 \\
\hline $\begin{array}{l}\text { Plans \& } \\
\text { Specifications }\end{array}$ & $\boldsymbol{1}$ & 12.5 \\
\hline $\begin{array}{l}\text { Construction } \\
\text { Methods }\end{array}$ & & 0 \\
\hline Equipment & & 0 \\
\hline $\begin{array}{l}\text { Third Party } \\
\text { Hindrance }\end{array}$ & 1 & 12.5 \\
\hline Quantity Variation & 2 & 25 \\
\hline $\begin{array}{l}\text { Unforeseen } \\
\text { Conditions }\end{array}$ & $\mathbf{3}$ & 37.5 \\
\hline Permit & & 0 \\
\hline TOTAL & $\mathbf{8}$ & $\mathbf{1 0 0}$ \\
\hline
\end{tabular}

Table 10: Frequency Analysis Result for District 3

\subsection{Winner-Loser, Money-Time Table}

The following table gives information about who opened the case, who won the case, what is the percentage rate of winning in this district. In what amount money and 
time the parties claimed, and finally it provides at what percentage the claimed time and money is won.

\begin{tabular}{|l|l|}
\hline \multicolumn{1}{|c|}{ Claimer } & 7 \\
\hline Contractor & 1 \\
\hline Owner/FDOT & \\
\hline
\end{tabular}

\begin{tabular}{|l|c|}
\hline \multicolumn{1}{|c|}{ Winner } & 6 \\
\hline Contractor & 1 \\
\hline Owner/FDOT & 1 \\
\hline & 14.28571429 \\
\hline of Winning (FDOT perspective) & 85.71428571 \\
\hline
\end{tabular}

\begin{tabular}{|l|l|}
\hline \multicolumn{2}{|c|}{ Money Claimed } \\
\hline $0-\$ 49,999$ & 1 \\
\hline$\$ 50,000-\$ 99,999$ & 0 \\
\hline$\$ 100,000-\$ 149,000$ & 0 \\
\hline$\$ 150,000$ \& above & 3 \\
\hline N/A & 4 \\
\hline
\end{tabular}

\begin{tabular}{|l|c|}
\hline \multicolumn{2}{|c|}{ Time Claimed } \\
\hline $0-25$ days & 0 \\
\hline 26days-50days & 1 \\
\hline 51 days-75 days & 1 \\
\hline 76 days and above & 2 \\
\hline N/A & 4 \\
\hline
\end{tabular}

Table 11: Winner-Loser, Money-Time Results for District 3 


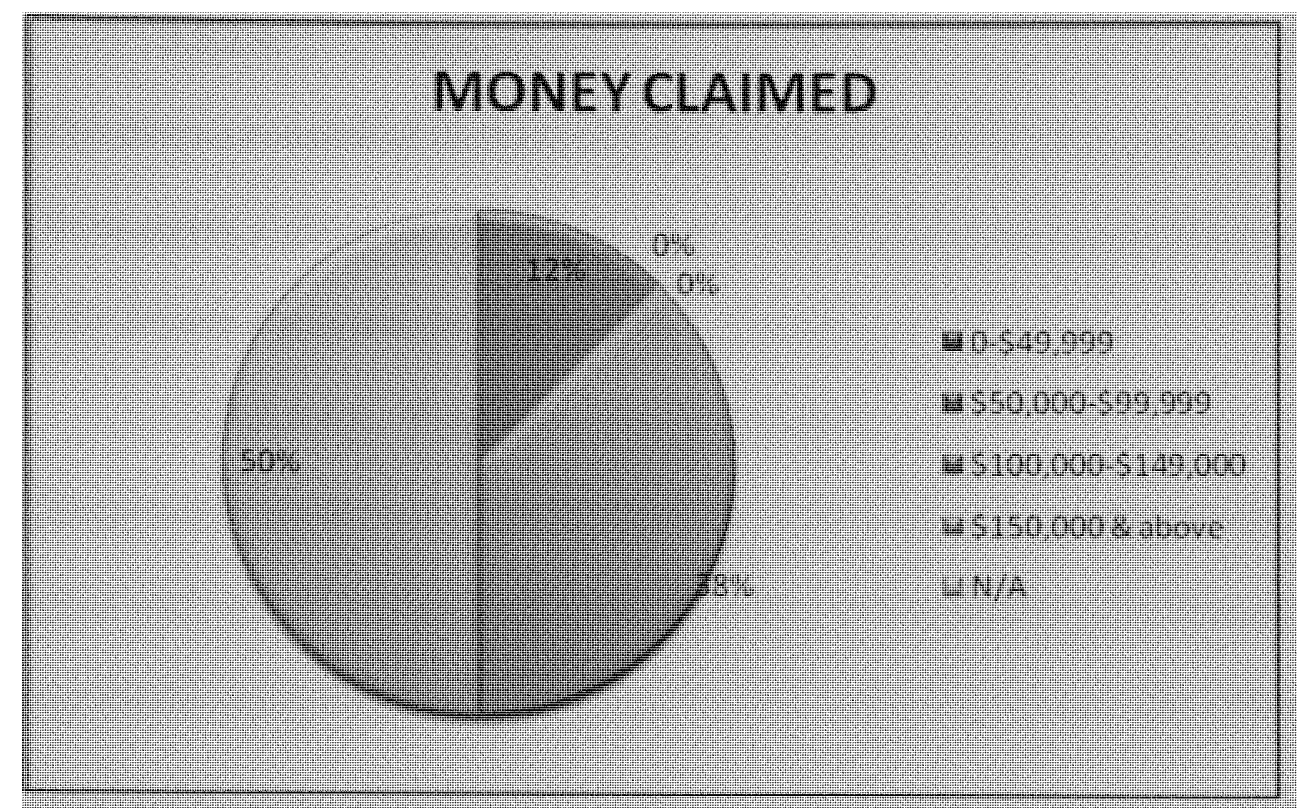

Figure 12: Money Claimed for District 3

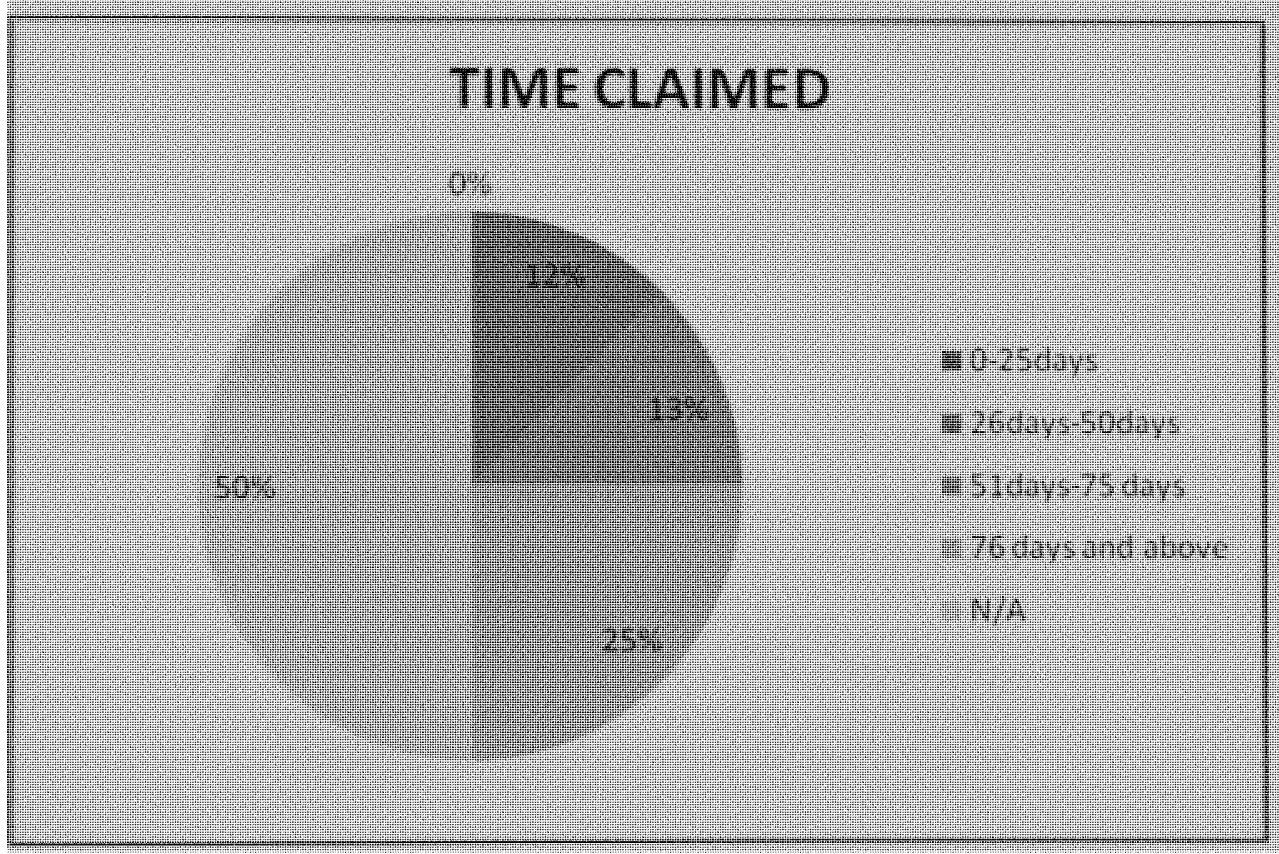

Figure 13: Time Claimed for District 3 


\subsubsection{District 4}

This district consists of fourteen disputes. All of the disputes are numbered starting from eighty eight to one hundred and one. This will help the user to find more detail in the dispute document for a desired type of dispute.

\subsection{Frequency analysis results}

Frequency analysis used a tabular form to represent the result of data analysis of frequency of each variable under categories. The result was tabulated in the form of frequency number and percentages according to total number of disputes. The following table illustrates the results of district \#4.

\begin{tabular}{|l|c|r|}
\hline \multicolumn{1}{|c|}{ Characteristics } & Number & \multicolumn{1}{c|}{$\%$} \\
\hline Material & 2 & 10.526 \\
\hline Quality & & 0 \\
\hline Safety & 2 & 10.526 \\
\hline $\begin{array}{l}\text { Plans \& } \\
\text { Specifications }\end{array}$ & 2 & 10.526 \\
\hline $\begin{array}{l}\text { Construction } \\
\text { Methods }\end{array}$ & & 0 \\
\hline Equipment & & 0 \\
\hline $\begin{array}{l}\text { Third Party } \\
\text { Hindrance }\end{array}$ & 1 & 5.2632 \\
\hline Quantity Variation & 7 & 36.842 \\
\hline $\begin{array}{l}\text { Unforeseen } \\
\text { Conditions }\end{array}$ & $\mathbf{4}$ & 21.053 \\
\hline Permit & $\mathbf{1}$ & 5.2632 \\
\hline TOTAL & $\mathbf{1 9}$ & $\mathbf{1 0 0}$ \\
\hline
\end{tabular}

Table 12: Frequency Analysis Result for District 4

\subsection{Winner-Loser, Money-Time Table}

The following table gives information about who opened the case, who won the case, what is the percentage rate of winning in this district. In what amount money and 
time the parties claimed, and finally it provides at what percentage the claimed time and money is won.

\begin{tabular}{|l|c|}
\hline \multicolumn{1}{|c|}{ Claimer } & 19 \\
\hline Contractor & 0 \\
\hline Owner/FDOT & \\
\hline
\end{tabular}

\begin{tabular}{|l|c|}
\hline \multicolumn{1}{|c|}{ Winner } & \\
\hline Contractor & 4 \\
\hline Owner/FDOT & 15 \\
\hline & \\
\hline \% of Winning (FDOT perspective) & 78,94736842 \\
\hline & 21,05263158 \\
\hline
\end{tabular}

\begin{tabular}{|l|c|}
\hline \multicolumn{2}{|c|}{ Money Claimed } \\
\hline $0-\$ 49,999$ & 2 \\
\hline$\$ 50,000-\$ 99,999$ & 0 \\
\hline$\$ 100,000-\$ 149,000$ & 0 \\
\hline$\$ 150,000 \&$ above & 1 \\
\hline N/A & 16 \\
\hline
\end{tabular}

\begin{tabular}{|l|c|}
\hline \multicolumn{2}{|c|}{ Time Claimed } \\
\hline $0-25$ days & 0 \\
\hline 26days-50days & 0 \\
\hline 51 days -75 days & 0 \\
\hline 76 days and above & 1 \\
\hline N/A & 18 \\
\hline
\end{tabular}

Table 13: Winner-Loser, Money-Time Results for District 4 


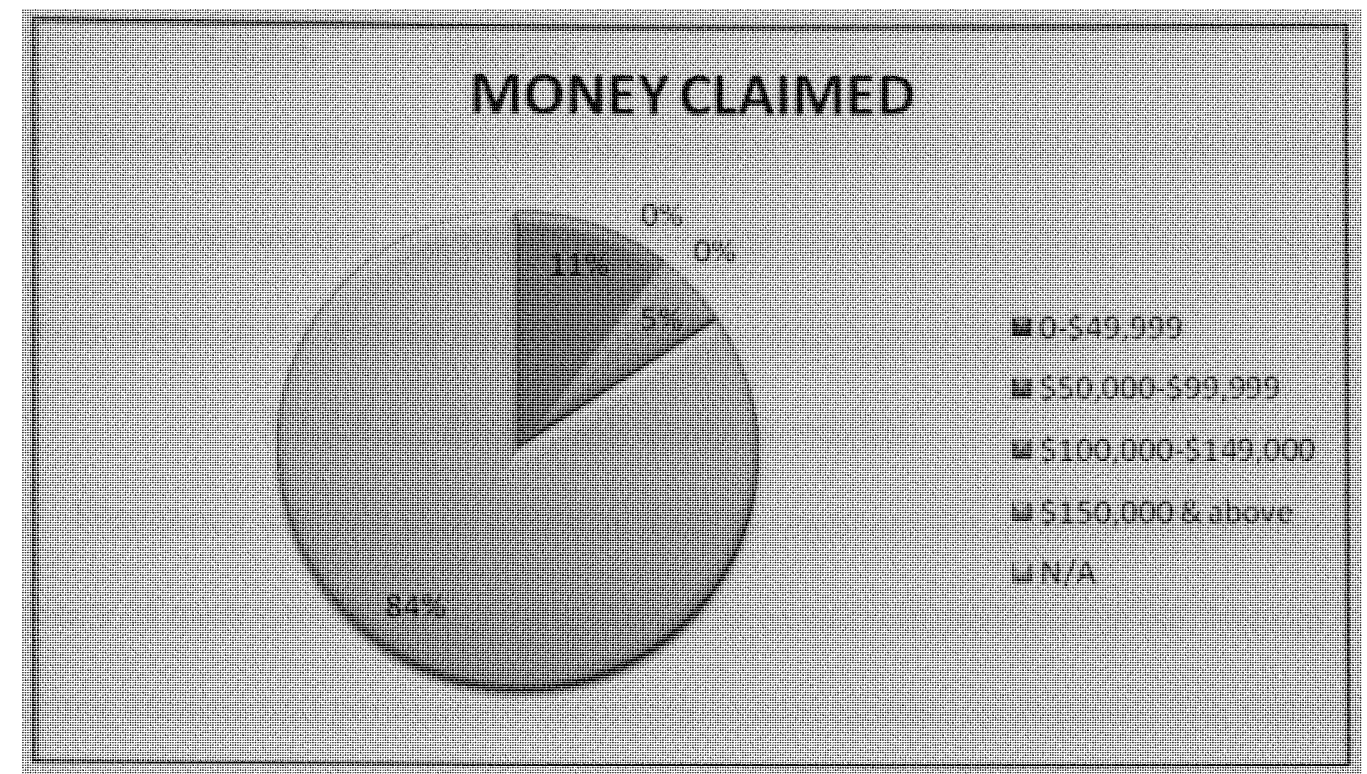

Figure 14: Money Claimed for District 4

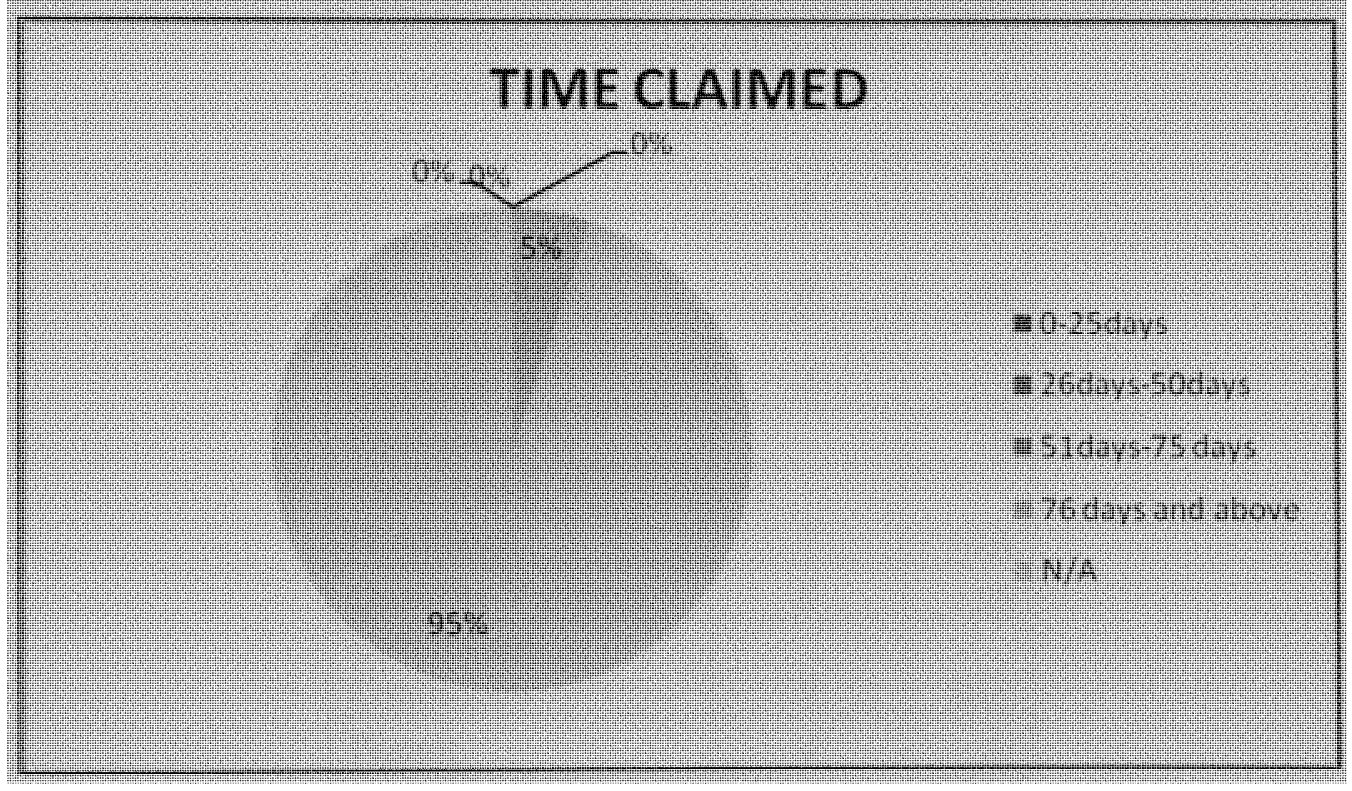

Figure 15: Time Claimed for District 4 


\subsubsection{District 5}

This district consists of thirty five disputes. All of the disputes are numbered starting from one hundred and two to one hundred and thirty six. This will help the user to find more detail in the dispute document for a desired type of dispute.

\subsection{Frequency analysis results}

Frequency analysis used a tabular form to represent the result of data analysis of frequency of each variable under categories. The result was tabulated in the form of frequency number and percentages according to total number of disputes. The following table illustrates the results of district \#5.

\begin{tabular}{|l|c|r|}
\hline \multicolumn{1}{|c|}{ Characteristics } & Number & $\%$ \\
\hline Material & 2 & 5 \\
\hline Quality & & 0 \\
\hline Safety & 1 & 2.5 \\
\hline $\begin{array}{l}\text { Plans \& } \\
\text { Specifications }\end{array}$ & 8 & 20 \\
\hline $\begin{array}{l}\text { Construction } \\
\text { Methods }\end{array}$ & 3 & 7.5 \\
\hline Equipment & & 0 \\
\hline $\begin{array}{l}\text { Third Party } \\
\text { Hindrance }\end{array}$ & 7 & 17.5 \\
\hline Quantity Variation & 6 & 15 \\
\hline $\begin{array}{l}\text { Unforeseen } \\
\text { Conditions }\end{array}$ & 9 & 22.5 \\
\hline Permit & 4 & 10 \\
\hline TOTAL & 40 & 100 \\
\hline
\end{tabular}

Table 14: Frequency Analysis Result for District 5

\subsection{Winner-Loser, Money-Time Table}

The following table gives information about who opened the case, who won the case, what is the percentage rate of winning in this district. In what amount money and 
time the parties claimed, and finally it provides at what percentage the claimed time and money is won.

\begin{tabular}{|l|c|}
\hline \multicolumn{1}{|c|}{ Claimer } & \\
\hline Contractor & 40 \\
\hline Owner/FDOT & 0 \\
\hline
\end{tabular}

\begin{tabular}{|l|c|}
\hline \multicolumn{1}{|c|}{ Winner } & 14 \\
\hline Contractor & 26 \\
\hline Owner/FDOT & \\
\hline & 65 \\
\hline \% of Winning (FDOT perspective) & 35 \\
\hline
\end{tabular}

\begin{tabular}{|l|c|}
\hline \multicolumn{2}{|c|}{ Money Claimed } \\
\hline $0-\$ 49,999$ & 3 \\
\hline$\$ 50,000-\$ 99,999$ & 4 \\
\hline$\$ 100,000-\$ 149,000$ & 0 \\
\hline$\$ 150,000 \&$ above & 1 \\
\hline N/A & 32 \\
\hline
\end{tabular}

\begin{tabular}{|l|c|}
\hline \multicolumn{2}{|c|}{ Time Claimed } \\
\hline $0-25$ days & 4 \\
\hline 26 days-50days & 2 \\
\hline 51 days-75 days & 3 \\
\hline 76 days and above & 3 \\
\hline N/A & 28 \\
\hline
\end{tabular}

Table 15: Winner-Loser, Money-Time Results for District 5 


\section{MONEY CLAIMED}

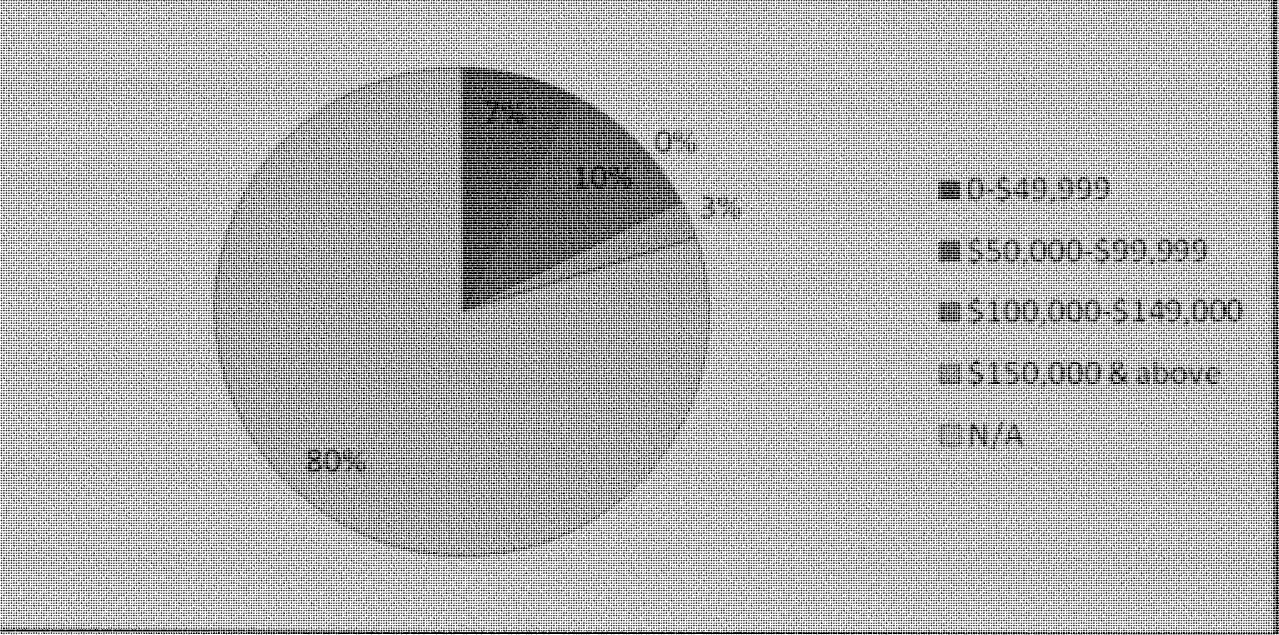

Figure 16: Money Claimed for District 5

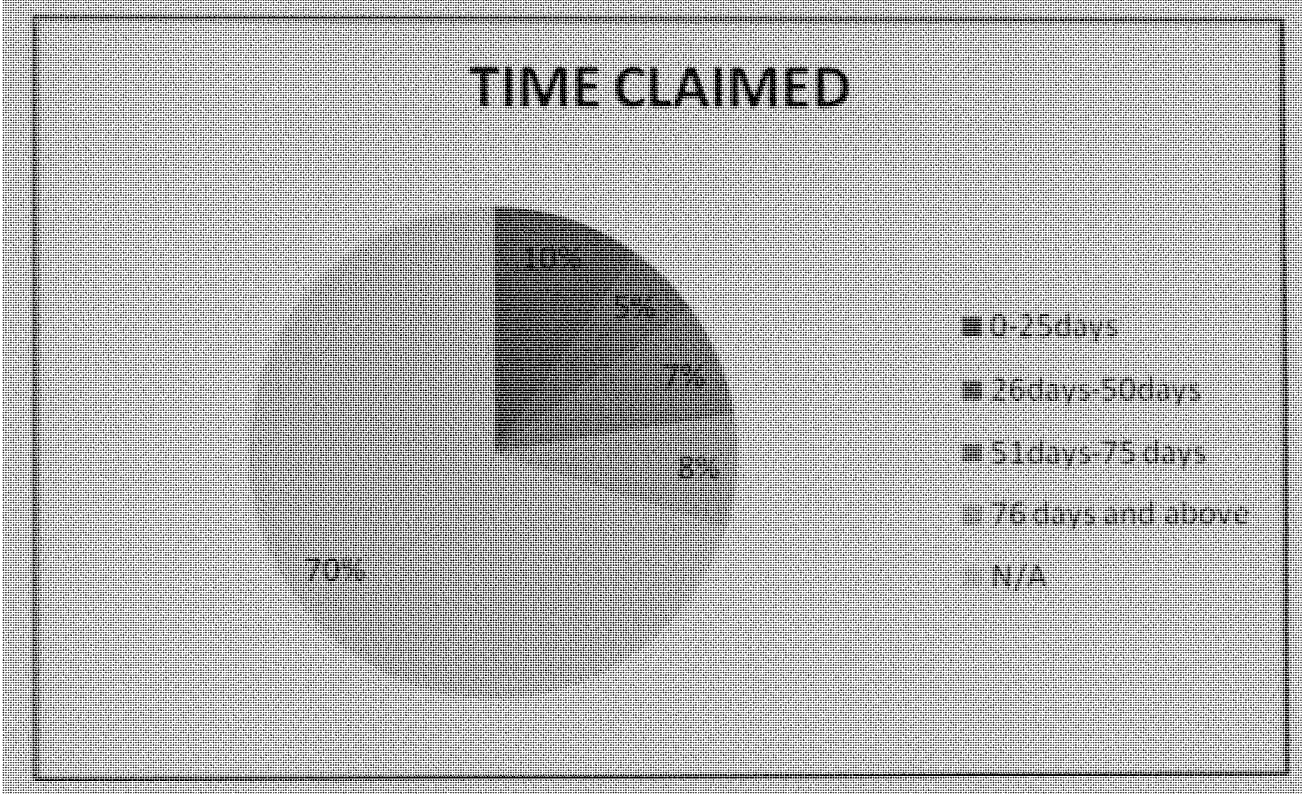

Figure 17: Time Claimed for District 5 


\subsubsection{District 6}

This district consists of only two disputes. All of the disputes are numbered starting from one hundred thirty seven to one hundred thirty eight. This will help the user to find more detail in the dispute document for a desired type of dispute.

\subsection{Frequency analysis results}

Frequency analysis used a tabular form to represent the result of data analysis of frequency of each variable under categories. The result was tabulated in the form of frequency number and percentages according to total number of disputes. The following table illustrates the results of district \#6.

\begin{tabular}{|c|c|c|}
\hline Characteristics & Number & $\%$ \\
\hline Material & & 0 \\
\hline Quality & & 0 \\
\hline Safety & & 0 \\
\hline $\begin{array}{l}\text { Plans \& } \\
\text { Specifications }\end{array}$ & 2 & 100 \\
\hline $\begin{array}{l}\text { Construction } \\
\text { Methods }\end{array}$ & & 0 \\
\hline Equipment & & 0 \\
\hline $\begin{array}{l}\text { Third Party } \\
\text { Hindrance }\end{array}$ & & 0 \\
\hline Quantity Variation & & 0 \\
\hline $\begin{array}{l}\text { Unforeseen } \\
\text { Conditions }\end{array}$ & & 0 \\
\hline Permit & & 0 \\
\hline TOTAL & 2 & 100 \\
\hline
\end{tabular}

Table 16: Frequency Analysis Result for District 6

\subsection{Winner-Loser, Money-Time Table}

The following table gives information about who opened the case, who won the case, what is the percentage rate of winning in this district. In what amount money and 
time the parties claimed, and finally it provides at what percentage the claimed time and money is won.

\begin{tabular}{|l|c|}
\hline \multicolumn{1}{|c|}{ Claimer } & \\
\hline Contractor & 2 \\
\hline Owner/FDOT & 0 \\
\hline
\end{tabular}

\begin{tabular}{|l|c|}
\hline \multicolumn{1}{|c|}{ Winner } & \\
\hline Contractor & 1 \\
\hline Owner/FDOT & 0 \\
\hline Negotiate & 1 \\
\hline & \\
\hline$\%$ of Winning (FDOT perspective) & 0 \\
\hline
\end{tabular}

\begin{tabular}{|l|l|}
\hline \multicolumn{2}{|c|}{ Money Claimed } \\
\hline $0-\$ 49,999$ & 0 \\
\hline$\$ 50,000-\$ 99,999$ & 0 \\
\hline$\$ 100,000-\$ 149,000$ & 0 \\
\hline$\$ 150,000 \&$ above & 0 \\
\hline N/A & 2 \\
\hline
\end{tabular}

\begin{tabular}{|l|l|}
\hline \multicolumn{2}{|c|}{ Time Claimed } \\
\hline 0 -25days & 0 \\
\hline 26days-50days & 0 \\
\hline 51days-75 days & 0 \\
\hline 76 days and above & 0 \\
\hline N/A & 2 \\
\hline
\end{tabular}

\section{Table 17: Winner-Loser, Money-Time Results for District 6}

In this district, the dispute reports did not contain any information about the monetary and time values. Therefore, the money claimed and time claimed results are unknown. 


\subsubsection{District 7}

This district consists of fifty five disputes. All of the disputes are numbered starting from one hundred thirty nine to one hundred ninety three. This will help the user to find more detail in the dispute document for a desired type of dispute.

\subsection{Frequency analysis results}

Frequency analysis used a tabular form to represent the result of data analysis of frequency of each variable under categories. The result was tabulated in the form of frequency number and percentages according to total number of disputes. The following table illustrates the results of district \#7.

\begin{tabular}{|l|c|r|}
\hline \multicolumn{1}{|c|}{ Characteristics } & Number & \multicolumn{1}{c|}{$\%$} \\
\hline Material & 15 & 25.862 \\
\hline Quality & 2 & 3.4483 \\
\hline Safety & & 0 \\
\hline $\begin{array}{l}\text { Plans \& } \\
\text { Specifications }\end{array}$ & 9 & 15.517 \\
\hline $\begin{array}{l}\text { Construction } \\
\text { Methods }\end{array}$ & 9 & 15.517 \\
\hline Equipment & & 0 \\
\hline $\begin{array}{l}\text { Third Party } \\
\text { Hindrance }\end{array}$ & & 0 \\
\hline Quantity Variation & 9 & 15.517 \\
\hline $\begin{array}{l}\text { Unforeseen } \\
\text { Conditions }\end{array}$ & $\mathbf{1 4}$ & 24.138 \\
\hline Permit & $\mathbf{5 8}$ & $\mathbf{1 0 0}$ \\
\hline TOTAL
\end{tabular}

Table 18: Frequency Analysis Result for District 7

\subsection{Winner-Loser, Money-Time Table}

The following table gives information about who opened the case, who won the case, what is the percentage rate of winning in this district. In what amount money and 
time the parties claimed, and finally it provides at what percentage the claimed time and money is won.

\begin{tabular}{|l|c|}
\hline \multicolumn{1}{|c|}{ Claimer } & 58 \\
\hline Contractor & 0 \\
\hline Owner/FDOT & 0 \\
\hline
\end{tabular}

\begin{tabular}{|l|c|}
\hline \multicolumn{1}{|c|}{ Winner } & \\
\hline Contractor & 25 \\
\hline Owner/FDOT & 28 \\
\hline Negotiate & 4 \\
\hline Indecision & 1 \\
\hline$\%$ of Winning (FDOT perspective) & 48,27586207 \\
\hline & 51,72413793 \\
\hline
\end{tabular}

\begin{tabular}{|l|c|}
\hline \multicolumn{2}{|c|}{ Money Claimed } \\
\hline $0-\$ 49,999$ & 3 \\
\hline$\$ 50,000-\$ 99,999$ & 1 \\
\hline$\$ 100,000-\$ 149,000$ & 2 \\
\hline$\$ 150,000 \&$ above & 1 \\
\hline N/A & 51 \\
\hline
\end{tabular}

\begin{tabular}{|l|c|}
\hline \multicolumn{2}{|c|}{ Time Claimed } \\
\hline $0-25$ days & 6 \\
\hline 26 days-50days & 1 \\
\hline 51 days-75 days & 0 \\
\hline 76 days and above & 5 \\
\hline N/A & 46 \\
\hline
\end{tabular}

Table 19: Winner-Loser, Money-Time Results for District 7 


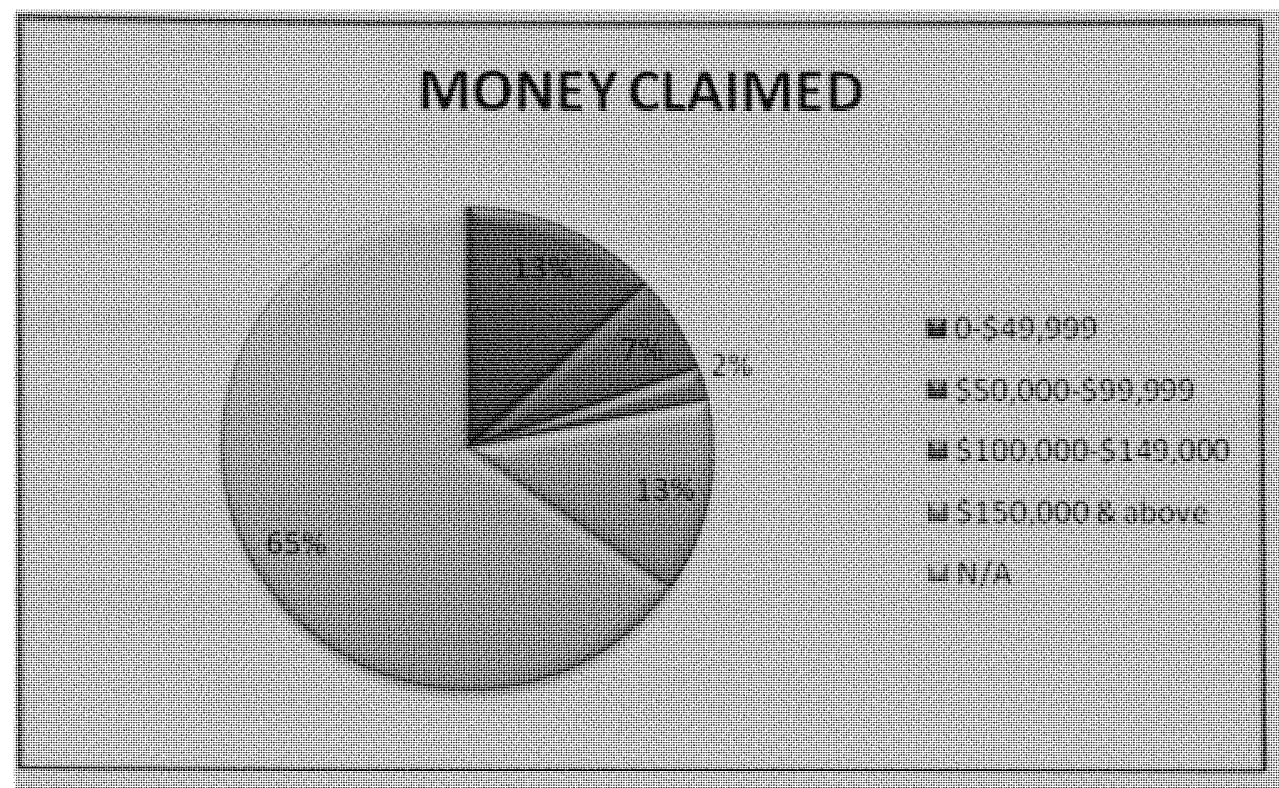

Figure 18: Money Clained for District 7

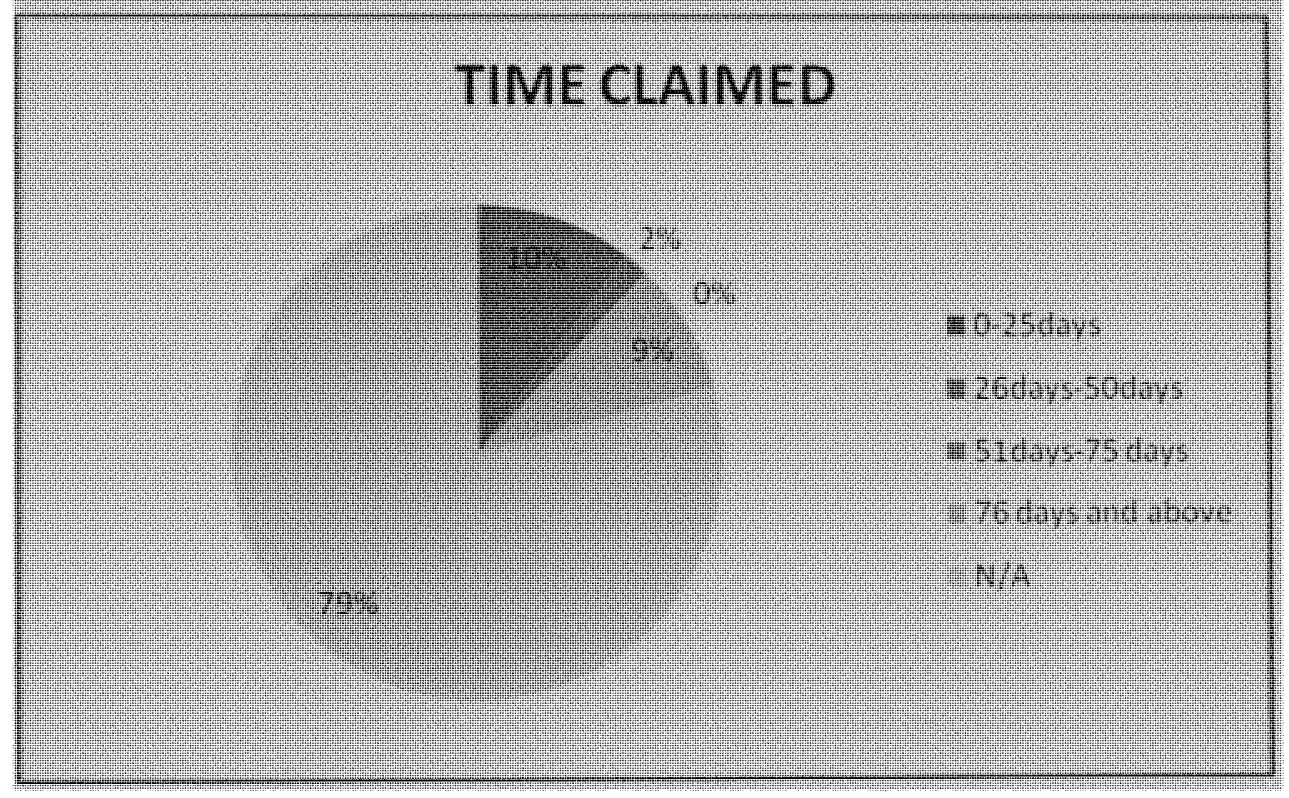

Figure 19: Time Claimed for District 7 


\subsubsection{District 8}

This district consists of forty one disputes. All of the disputes are numbered starting from one hundred ninety four to two hundred thirty four. In this section two documents are excluded from total. The reason for this exclusion is that one of the documents is notice of termination not a dispute. Other document, number 231 in the district 8 is the same one with number 199. Therefore they were excluded. Moreover, number 189 does not have sufficient information to be categorized.

\subsection{Frequency analysis results}

Frequency analysis used a tabular form to represent the result of data analysis of frequency of each variable under categories. The result was tabulated in the form of frequency number and percentages according to total number of disputes. The following table illustrates the results of district \#8.

\begin{tabular}{|l|c|c|}
\hline \multicolumn{1}{|c|}{ Characteristics } & Number & $\%$ \\
\hline Material & $\mathbf{3}$ & 6.5217 \\
\hline Quality & 2 & 4.3478 \\
\hline Safety & 2 & 4.3478 \\
\hline $\begin{array}{l}\text { Plans \& } \\
\text { Specifications }\end{array}$ & 7 & 15.217 \\
\hline $\begin{array}{l}\text { Construction } \\
\text { Methods }\end{array}$ & 4 & 8.6957 \\
\hline Equipment & 1 & 2.1739 \\
\hline $\begin{array}{l}\text { Third Party } \\
\text { Hindrance }\end{array}$ & 2 & 4.3478 \\
\hline Quantity Variation & $\mathbf{1 7}$ & 36.957 \\
\hline $\begin{array}{l}\text { Unforeseen } \\
\text { Conditions }\end{array}$ & 6 & 13.043 \\
\hline Permit & $\mathbf{2}$ & 4.3478 \\
\hline TOTAL & $\mathbf{4 6}$ & $\mathbf{1 0 0}$ \\
\hline
\end{tabular}

Table 20: Frequency Analysis Result for District 8 


\subsection{Winner-Loser, Money-Time Table}

The following table gives information about who opened the case, who won the case, what is the percentage rate of winning in this district. In what amount money and time the parties claimed, and finally it provides at what percentage the claimed time and money is won.

\begin{tabular}{|l|c|}
\hline \multicolumn{1}{|c|}{ Claimer } & \\
\hline Contractor & 46 \\
\hline Owner/FDOT & 0 \\
\hline
\end{tabular}

\begin{tabular}{|l|c|}
\hline \multicolumn{1}{|c|}{ Winner } & 16 \\
\hline Contractor & 26 \\
\hline Owner/FDOT & 4 \\
\hline Negotiate & 0 \\
\hline Indecision & 56,52173913 \\
\hline$\%$ of Winning (FDOT perspective) & 43,47826087 \\
\hline
\end{tabular}

\begin{tabular}{|l|c|}
\hline \multicolumn{2}{|c|}{ Money Claimed } \\
\hline $0-\$ 49,999$ & 6 \\
\hline$\$ 50,000-\$ 99,999$ & 3 \\
\hline$\$ 100,000-\$ 149,000$ & 1 \\
\hline$\$ 150,000 \&$ above & 6 \\
\hline N/A & 30 \\
\hline
\end{tabular}

\begin{tabular}{|l|c|}
\hline \multicolumn{2}{|c|}{ Time Claimed } \\
\hline 0 -25days & 12 \\
\hline 26 days-50days & 1 \\
\hline 51 days-75 days & 0 \\
\hline 76 days and above & 2 \\
\hline N/A & 31 \\
\hline
\end{tabular}

Table 21: Winner-Loser, Money-Time Results for District 8 


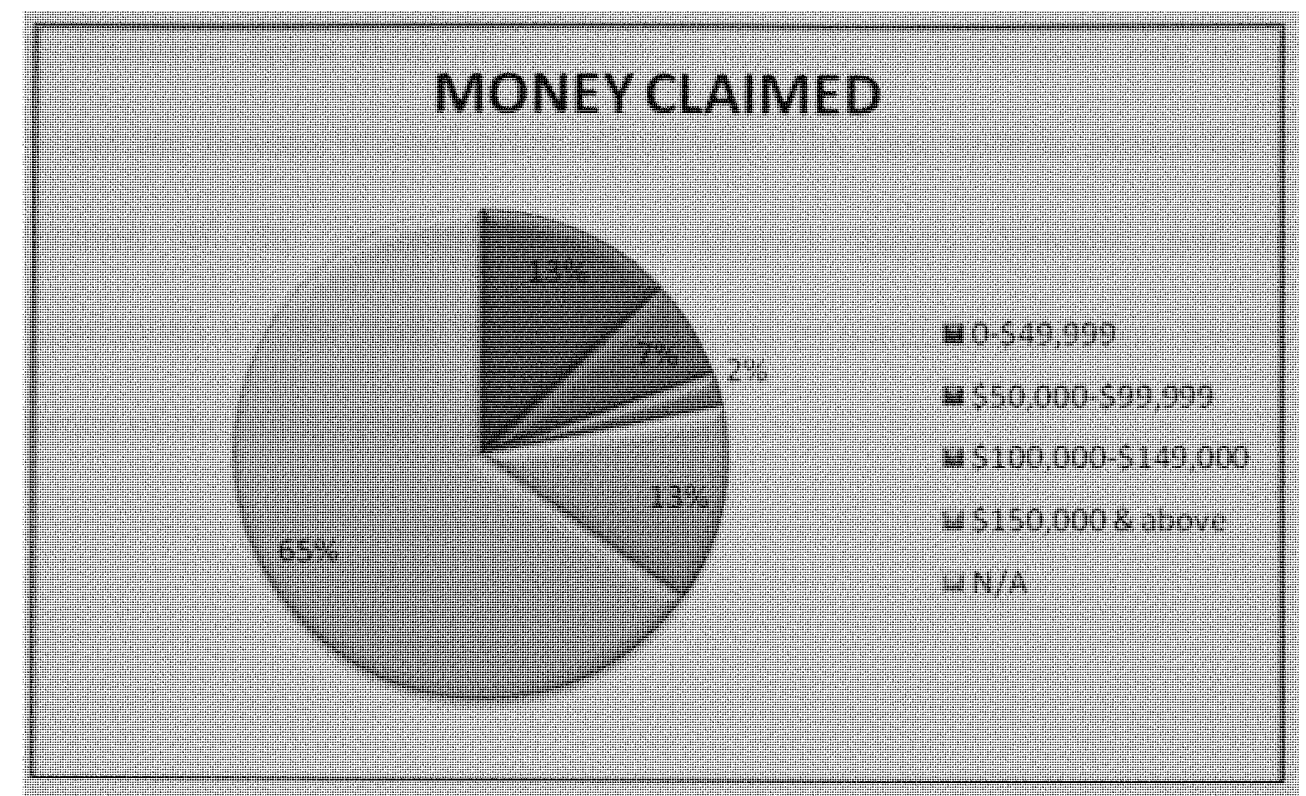

Higure 20: Money Claimed for Distriot 8

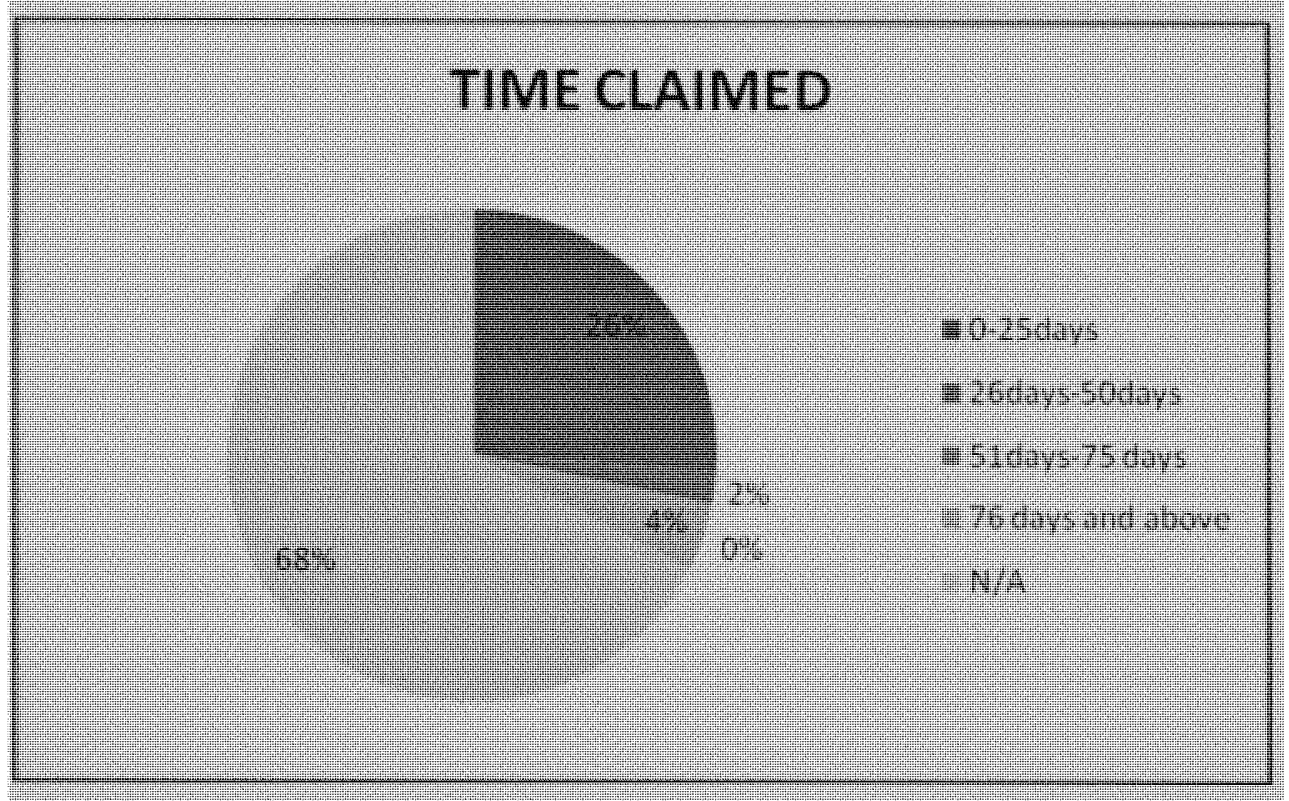

Figure 21: Time Claimed for District 8

\subsection{Results and Recommendation}

Based on the results obtained, conclusions and recommendations were developed.

Conclusions are drawn based on the findings and analysis of the results in accordance with the research objectives. To get benefit from the lessons learned, 
contract document items stated above can be adjusted in a detailed way to help the industry use the lessons learned more effectively. The next section shows the detailed categorization of the disputes by using project stages. Specific and practical recommendations will be made in the next chapter to handle the disputes for the better performance of the industry in future. 


\section{LESSONS LEARNED DOCUMENT}

\subsection{Introduction}

In this chapter, the detailed categorization is explained. Each single dispute is placed under one of the main categories: Permit, site work, foundation, construction, landscaping, and other. These categories are developed by conducting a great deal research on many types of project stages. In addition to this, for making situation assessment (checking old cases and comparing them with the new cases) easy for the user, each main category stated above has sub-categories. For category permit, there are four sub categories including ten disputes in total (\%4): Environmental permit, lane closure, site access and other. For site work, there is only one sub category which is fence. Foundation category has fifty two disputes (\%20). It has defective specifications/plans, base material/other, base material/shortage, earth wall, footing, sheet pile, excavation, bridge joints, additional unforeseen work, and hauling as sub categories. For construction, the number of disputes is $153(\% 58)$. Sub categories for this heading can be listed as follows: Concrete work, concrete/asphalt/slab, concrete side walk, truncated domes, utility work, insulation, material, restriction, bridge deck, defective specifications/plan, control of work, maintenance of traffic, additional unforeseen work, equipment, tests, noise ordinance suspension, changed site conditions, non-payment, workers compensation cost. Landscaping consists of twenty disputes (\%8). The sub categories of landscaping are; driveways, sod installation/ seeding/ fertilizing/ mulching/ mowing, pond, additional unforeseen condition, and other. For the main category "other", it collects all items which can not be placed under one of main categories stated above, in total twenty four disputes (\%9). The sub categories are as follows: Specialty engineer, 
contractual document, change in scope of work, delay, fire hydrant, discharge of superintendant, overhead expense, liquated damage, incentive-disincentive, stand-by cost of crew, off duty law enforcement, traffic accident, bridge clearance, schedule interpretation, vandalism/stolen, changed market price. More detailed information is provided in the next sections of this chapter.

\subsection{Project Stages}

\subsubsection{Permit}

In this category there are ten disputes found in the DRB database. Most confronted dispute is related with environmental permit issues $(50 \%)$. The following table illustrates the findings under this category. The numbers in the cells represent number of disputes found under specified district. D1 to D8 are the abbreviations of the district numbers i.e.: district one is D1.

\begin{tabular}{|l|c|c|c|c|c|c|c|c|c|}
\hline & $D 1$ & $D 2$ & $D 3$ & $D 4$ & $D 5$ & $D 6$ & 07 & 08 & SUM \\
\hline Permit & & & & & & & & & 10 \\
\hline Environmental Permit & 3 & 1 & & & 1 & & & & 5 \\
\hline Lane closure & & & & 2 & & & 1 & & 3 \\
\hline Site Access & & & & & & & & 1 & 1 \\
\hline Other & & & & & 1 & & & & 1 \\
\hline
\end{tabular}

Table 22: Number of Disputes for Permit Stage

\subsubsection{Site Work}

The following table provides information about the number of disputes under each district for this category.

\begin{tabular}{|c|c|c|c|c|c|c|c|c|c|}
\hline & $D 1$ & $D 2$ & $D 3$ & $D 4$ & $D 5$ & $D 6$ & 07 & $D 8$ & SUM \\
\hline Site Work & & & & & & & & & 3 \\
\hline Fence & 1 & 1 & & & & & 1 & & 3 \\
\hline
\end{tabular}

Table 23: Number of Disputes for Site Work Stage 


\subsubsection{Foundation}

The following table illustrates the disputes for the foundation category. The top three types of dispute issues observed for this category can be listed as: sheet pile (\%23), bridge joints (\%15), and the final one is additional unforeseen condition (\%12).

\begin{tabular}{|l|c|c|c|c|c|c|c|c|c|}
\hline & $D 1$ & $D 2$ & $D 3$ & $D 4$ & 05 & 06 & 07 & 08 & SUM \\
\hline Foundation & & & & & & & & & 52 \\
\hline Defective Specifications/Plan & 3 & & & & & & & & 3 \\
\hline Base Material/Other & 1 & 1 & & & 2 & & 3 & 1 & 8 \\
\hline Base Material/Shortage & & & & 1 & 1 & & 1 & & 3 \\
\hline Earth Wall & & & & & 1 & & & 3 & 4 \\
\hline Footing & & & & & & & & & \\
\hline Replacement & & & & & & 1 & 1 & & 2 \\
\hline Shaft & & 2 & 2 & 2 & 3 & & 1 & 2 & 12 \\
\hline Sheet Pile & & & & 2 & & & 1 & 1 & 4 \\
\hline Excavation & & & 2 & & 1 & & 3 & 2 & 8 \\
\hline Bridge Joints & 3 & & & & & & 1 & 2 & 6 \\
\hline Additional Unforeseen Condition & & & & & & & 1 & & 1 \\
\hline Hauling & & & & \\
\hline
\end{tabular}

Table 24: Number of Disputes for Foundation Stage

\subsubsection{Construction}

The following table illustrates the disputes for the construction category. The top three types encountered for this category can be listed as: additional unforeseen conditions (\%17), utility conflict (\%8), and the concrete/slab/asphalt (\%8). 


\begin{tabular}{|c|c|c|c|c|c|c|c|c|c|}
\hline & D1 & $D 2$ & $D 3$ & $D 4$ & D5 & $D 6$ & 07 & $D 8$ & SUM \\
\hline Construction & & & & & & & & & 153 \\
\hline Concrete Work & 1 & 1 & & & 2 & & 2 & 3 & 9 \\
\hline Concrete/Asphalt/Slab & 2 & 3 & 1 & & 1 & & 2 & 3 & 12 \\
\hline Concrete Side Walk & 1 & & & & 1 & & & & 2 \\
\hline Truncated Domes & 2 & & & & & & & & 2 \\
\hline \multicolumn{10}{|l|}{ Utility Work } \\
\hline Electrical Rough-in & 3 & & 1 & & & & 1 & 3 & 8 \\
\hline Water Rough-in & 3 & & & 1 & 3 & & & & 7 \\
\hline \multicolumn{10}{|l|}{ Specialty Rough-ins } \\
\hline Phone & 1 & & & & & & & & 1 \\
\hline Cable Tv Service & 2 & & & & & & & & 2 \\
\hline Gas Utility & 2 & & & & & & & & 2 \\
\hline Relocation & & & & & 2 & & 1 & & 3 \\
\hline Conflict & 5 & & 1. & & 4 & 1 & & 2 & 13 \\
\hline Drainage Utility/Sanitary Sewer Utility & 5 & 1 & & & 1 & & 2 & & 9 \\
\hline Insulation(Coating) & & & & & 2 & & 1. & 2 & 5 \\
\hline \multicolumn{10}{|l|}{ Material } \\
\hline Unsuitable Material & & & & 2 & & & 1 & & 3 \\
\hline Extra & & 1 & & & 1. & & 1 & & 3 \\
\hline Shortage & & & & & 1. & & 2 & & 3 \\
\hline Traffic Signals & 2 & & & & & & 2 & 1 & 5 \\
\hline Repair/Replace & 1 & & & & & & 1 & & 2 \\
\hline Restriction & & & 1 & & & & & & 1 \\
\hline Bridge Deck & & 1 & & & & & & & 1 \\
\hline Defective Specifications/Plan & & 1 & & & & & 1 & 1 & 3 \\
\hline Control of Work & 1. & & 1 & & & & & & 2 \\
\hline Maintenance of Traffic & 1 & 1 & & 1 & 1 & & 1 & 2 & 7 \\
\hline Additional Unforeseen Work & 7 & 1. & 2 & 3 & 3 & & 3 & 7 & 26 \\
\hline \multicolumn{10}{|l|}{ Equipment } \\
\hline Idle & 1 & & & & & & & & 1 \\
\hline Other & 1 & & & 1 & & & 1 & 1 & 4 \\
\hline Tests & & & & & 1 & & & 1 & 2 \\
\hline Noise Ordinance Suspension & & & & 1 & & & & & 1 \\
\hline Changed Site Conditions & 2 & & & 1 & 1 & 1 & 1 & 2 & 8 \\
\hline Non-Payment & & & & & & & 1 & 3 & 4 \\
\hline Workman compensation cost & & & & & 1 & & & 1 & 2 \\
\hline
\end{tabular}

Table 25: Number of Disputes for Construction Stage

\subsubsection{Land Scaping}

Land scaping has six disputes in the top three categories; driveways (\%30), sod installation/seeding/fertilizing/mulching/mowing (\%30), and additional unforeseen condition (\%30). 


\begin{tabular}{|l|c|c|c|c|c|c|c|c|c|}
\hline & $D 1$ & 02 & 03 & $D 4$ & 05 & 06 & 07 & 08 & SUM \\
\hline Landscaping & & & & & & & & & 20 \\
\hline Driveways & 2 & & & & 2 & 1 & 1 & & 6 \\
\hline Sod Installation, Seeding, Fertilizing, Mulching, Mowing & 1 & & & & 1 & & 3 & 1 & 6 \\
\hline Pond & & & & & & & 1 & & 1 \\
\hline Other & 1 & & & & & & & & 1 \\
\hline Additional Unforeseen & 6 & & & & & & & & 6 \\
\hline
\end{tabular}

Table 26: Number of Disputes for Land Scaping Stage

\subsubsection{Other}

This category includes items that could not be placed under one of the categories stated above. Most frequently seen one in this category is delay problem (\%33).

\begin{tabular}{|l|c|c|c|c|c|c|c|c|c|}
\hline & $D 1$ & 02 & $D 3$ & 04 & 05 & $D 6$ & 07 & $D 8$ & SUM \\
\hline Other & & & & & & & & & 24 \\
\hline Speciality Engineer & 1 & & & & & & & & 1 \\
\hline Contractual Document & & & 1 & & & & & 1 & 2 \\
\hline Change in Scope of Work & & & & & & & 1 & & 1 \\
\hline Delay & 1 & & & & & & & & 1 \\
\hline Fire Hydrant & 1 & & & & & & & & 1 \\
\hline Discharge of Superintendant & & 1 & & & & & & & 1 \\
\hline Overhead Expense & & & 1 & & & & & & 1 \\
\hline Liquated Damage & & & & & & & 1 & & 1 \\
\hline Incentive-Disincentive & & & & & 1 & & & & 1 \\
\hline Stand-by cost of crew & & & & & 1 & & & & 1 \\
\hline Off duty law enforcement & & & & & & & 1 & & 1 \\
\hline Traffic accident & & & & & & & & 1 & 1 \\
\hline Bridge Clearance & & & & & & & & 1 & 1 \\
\hline Schedule Interpretation & & & & \\
\hline Vandalism/Stolen & & & & & & & 1 & 1 \\
\hline Changed Market Price & & & & & \\
\hline
\end{tabular}

Table 27: Number of Disputes for Other Stage

\subsection{Lessons Learned}

\subsubsection{Introduction}

The lessons learned documents and disseminates in the fields of project stages; permit, site work, foundation, construction, landscaping, and other. Through participatory monitoring, evaluation and documentation techniques, it aims to build a strong 
knowledge base and serve to provide lessons learned documented and recommendations from the previous cases.

Since each project is unique, lessons learned for each project is also different and unique from each other. However, they can be collected in a general way that users get benefit from the lessons learned and can adjust the previous cases to match new cases accordingly. To illustrate, one contractor is in a project with the FDOT to construct asphalt road. He wants to check the lessons learned to get benefit from the past cases to avoid the same mistakes regarding the material. The materials that were used in the previous cases may vary depending on the location, climate and other factors from project to project. However, lessons learned provided in this section are developed saying that "make sure that contract documents defines the scope of work about materials, and also defines how the payment will be made for the work." So the user can understand that in the past, there were some problems about this item. So, by taking into consideration, the user can apply lessons learned by carefully checking the contract documents and making sure that it defines scope of the work about the materials and the payments related. The user can adjust the lessons according to his/her project to promote recurring of the positive outcomes and discourage the recurrence of the negative outcomes. The next sections of this chapter will provide a better understanding of lessons learned.

\subsubsection{Lessons Learned-PERMIT}

In the following table the lessons learned for the permit section are provided. $\mathrm{C} 1$ and $\mathrm{C} 2$ are abbreviations of category 1 and category 2 respectively. In the description tab, the reasons of the disputes are explained. In the lessons learned tab, suggestions are made in a broad perspective allowing the user to adjust the lessons to their projects. 


\begin{tabular}{|c|c|c|c|}
\hline a. & 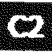 & Desaiption & 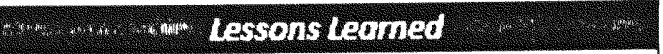 \\
\hline \multirow{7}{*}{$\frac{E}{0}$} & \multirow{3}{*}{ 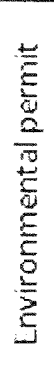 } & $\begin{array}{l}\text { Permit/Environmental permit- } \\
\text { Wight-time work }\end{array}$ & \multirow{2}{*}{$\begin{array}{l}\text { Make sure to make the Department procure } \\
\text { allenvionmental permits required by } \\
\text { Federal. State county and local regulatory } \\
\text { agencies }\end{array}$} \\
\hline & & $\begin{array}{l}\text { US Coast Guard-Construction } \\
\text { Work Permit }\end{array}$ & \\
\hline & & $\begin{array}{l}\text { Permit/Environmental Permit- } \\
\text { Water System Connection Pemit } \\
\text { oetween Different Counties }\end{array}$ & $\begin{array}{l}\text { - DOT was the party responsble for the } \\
\text { procurement of the proper water permits } 0 \\
\text { cover all the necessary project work on ste }\end{array}$ \\
\hline & \multirow{2}{*}{$\begin{array}{l}\frac{0}{3} \\
\frac{0}{0} \\
\frac{0}{3}\end{array}$} & $\begin{array}{l}\text { Permit/Lane Closure-Traffic } \\
\text { Control-Safety Officers }\end{array}$ & $\begin{array}{l}\text { Define clearly Paymentitems (Traffic } \\
\text { Control Officersin the contract documents }\end{array}$ \\
\hline & & $\begin{array}{l}\text { Permithane closure- } \\
\text { Requirements }\end{array}$ & $\begin{array}{l}\text { Define cleary the requirements for bane } \\
\text { cosure in the plans for each specific acturyty }\end{array}$ \\
\hline & $\frac{3}{3}$ & Permilsite Access-Allowance & $\begin{array}{l}\text { is the DET's responsiblity to provide } \\
\text { access to ste. }\end{array}$ \\
\hline & $\frac{\frac{1}{0}}{5}$ & $\begin{array}{l}\text { Permitiother-Restrictions on } \\
\text { other construction activities such } \\
\text { as :Burng operations of } \\
\text { clearing and grubbing debris etc. }\end{array}$ & $\begin{array}{l}\text { Define cleary the restrictons and permits at } \\
\text { the the of bidding to the contractor, and no } \\
\text { change s a byed after the the of bidding } \\
\text { uness the OET accepts to compensate the } \\
\text { contractor for this change }\end{array}$ \\
\hline
\end{tabular}

\section{Figure 22: Lessons Learned for Permit}

\subsubsection{Lessons Learned-SITE WORK}

This section provides lessons learned for the site work. In this section, fence is the only subsection under the site work category.

\begin{tabular}{|c|c|c|c|}
\hline & & & 12 \\
\hline$\frac{5}{3}$ & $\stackrel{\mathscr{U}}{\underline{I}}$ & $\begin{array}{l}\text { Site Work/Fence-Change in } \\
\text { Character of work in bulding } \\
\text { fence due to some reasons: } \\
\text { supplier, contractor, weather etc. }\end{array}$ & $\begin{array}{l}\text { Engineer is the responsible person } \\
\text { determining that the character of the vork } \\
\text { as attered differs materially in kind or } \\
\text { nature. }\end{array}$ \\
\hline
\end{tabular}

Figure 23: Lessons Learned for Site Work 


\subsubsection{Lessons Learned-FOUNDATION}

In the following table the lessons learned for the foundation section are provided.

\section{c1}

$\infty$

Descripion

Lexsons Leamed

\begin{tabular}{|c|c|c|}
\hline \multirow{4}{*}{$\begin{array}{l}\frac{2}{5} \\
3 \\
\frac{5}{9} \\
0 \\
0 \\
\frac{3}{0} \\
\frac{5}{5} \\
\frac{2}{0} \\
\frac{5}{5} \\
\frac{5}{3} \\
3\end{array}$} & $\begin{array}{l}\text { Foundation/Additonal } \\
\text { Unforeseen Work-Unexpected } \\
\text { soll condition while excavation }\end{array}$ & \multirow{4}{*}{ 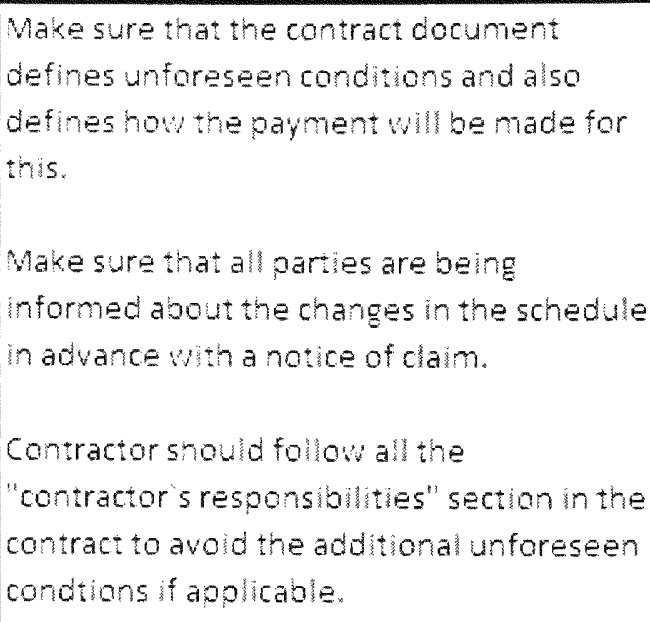 } \\
\hline & $\begin{array}{l}\text { Foundation/Addrona: } \\
\text { Unforeseen Work-Unexpected } \\
\text { Water Table Helght }\end{array}$ & \\
\hline & $\begin{array}{l}\text { Foundation Addichal } \\
\text { Unforeseen Work-lmpact to the } \\
\text { Schedule beyond the control of } \\
\text { the Contractor }\end{array}$ & \\
\hline & $\begin{array}{l}\text { Foundation/Additonal } \\
\text { Unforeseen Work-Unexpected } \\
\text { falure of Erosion Controlsystem }\end{array}$ & \\
\hline $\bar{Q}$ & $\begin{array}{l}\text { Foundation/Base Material } \\
\text { (Shortage\&Other)-Area-wide } \\
\text { shortage of BaseMaterlal }\end{array}$ & $\begin{array}{l}\text { Define the specifications regarding base } \\
\text { materia chearly in the contractual } \\
\text { documents. }\end{array}$ \\
\hline $\begin{array}{l}\Xi \\
2 \\
0\end{array}$ & $\begin{array}{l}\text { Delay in placement of the } \\
\text { bedding materal }\end{array}$ & Define clearly Contract The Extensions in \\
\hline$\frac{5}{\frac{3}{0}}$ & $\begin{array}{l}\text { Foundation/8ase Material } \\
\text { (shortage\&Other)-Collapse of } \\
\text { the previous base white placing } \\
\text { new base on top of it }\end{array}$ & the comractual documents. \\
\hline
\end{tabular}

Figure 24: Lessons Learned for Foundation a 


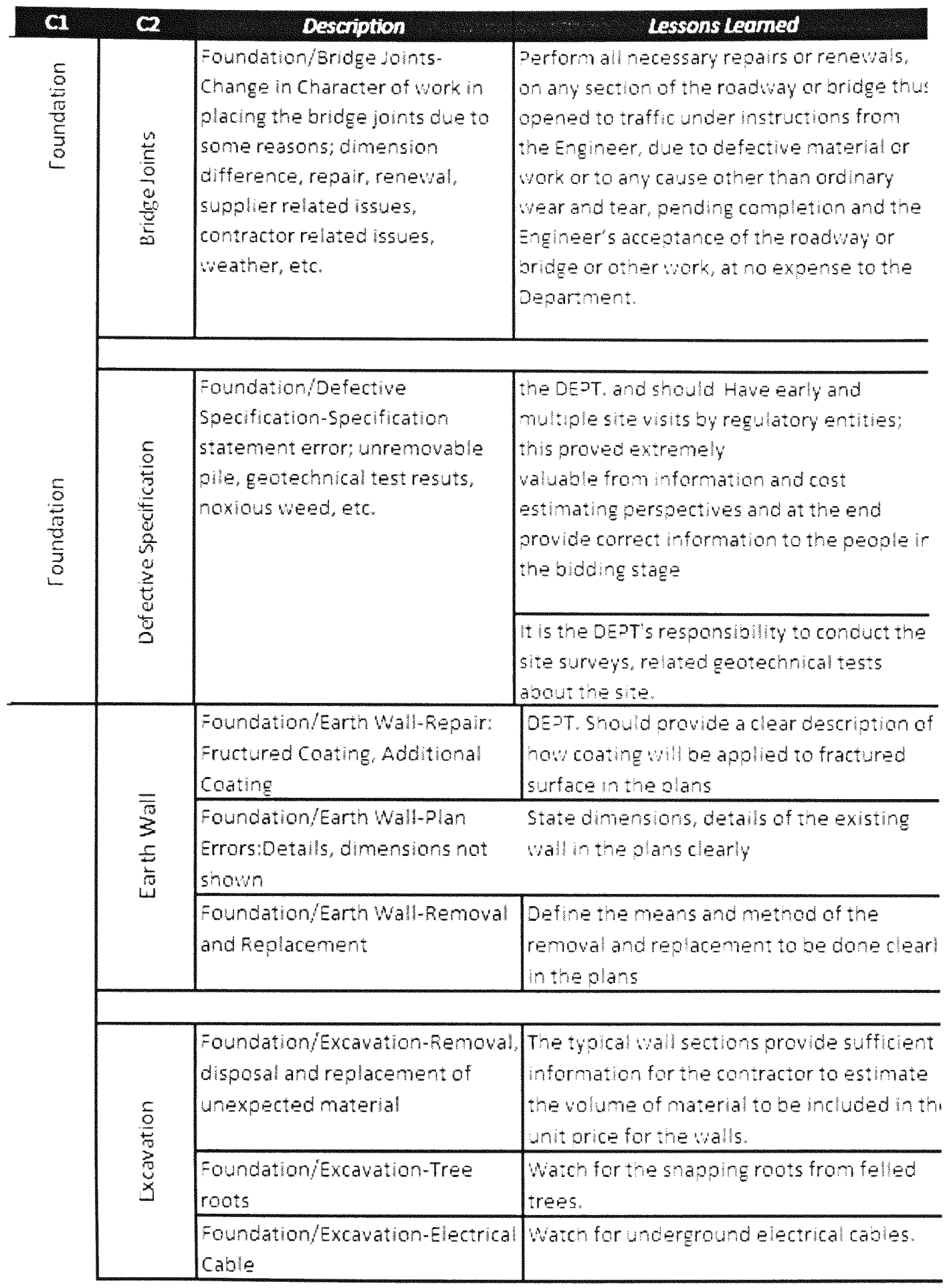

Figure 25: Lessons Learned for Foundation $b$ 


\begin{tabular}{|c|c|c|c|}
\hline C1 & $\theta$ & Desciption & Lescons Leomed \\
\hline \multirow[t]{5}{*}{ 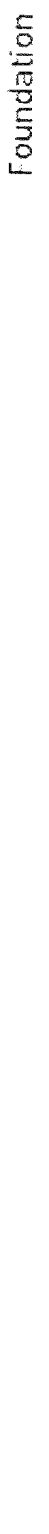 } & 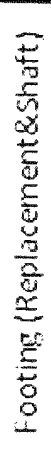 & $\begin{array}{l}\text { Foundation/Footing } \\
\text { feplacement\&shaft) } \\
\text { Beplacement is needed due to } \\
\text { bad concrete pouring and curing. } \\
\text { Foundation/Footing } \\
\text { Replacement\&5haft-femoval } \\
\text { of the obstructions from orimed } \\
\text { shafts }\end{array}$ & $\begin{array}{l}\text { =oot is the responsiole party to take care of } \\
\text { the curng and pourng processes. } \\
\text { befine removal of the any materal from the } \\
\text { shafis cleary in the specifications. }\end{array}$ \\
\hline & $\frac{\sum}{\frac{5}{2}}$ & $\begin{array}{l}\text { Foundation/Haulng-Muck } \\
\text { Materals }\end{array}$ & $\begin{array}{l}\text { The DEPT, and should Have early and } \\
\text { mutiole ste vists by regulatory entities: } \\
\text { this proved extremely valuable from } \\
\text { formation and cost estimathe } \\
\text { perspectues and at the end provide correct } \\
\text { formation to the people in the bidding } \\
\text { stage }\end{array}$ \\
\hline & \multirow{3}{*}{$\frac{\frac{a}{2}}{\frac{8}{\sqrt{3}}}$} & $\begin{array}{l}\text { Foundation/sheet phe-problem } \\
\text { to divert and maintain flow and } \\
\text { prevent the fiow of the turbud } \\
\text { Waterinto the cand during } \\
\text { construction whin the canal }\end{array}$ & $\begin{array}{l}\text { Contractor is required to submit a notice of } \\
\text { intent to dam prior to beginning work on } \\
\text { which the clam is based. }\end{array}$ \\
\hline & & $\begin{array}{l}\text { Foundation/sheet Ple-The } \\
\text { requrement for edge drams }\end{array}$ & $\begin{array}{l}\text { AllooT manuas spectications and indexes } \\
\text { must show that edgedran is needed in al } \\
\text { area }\end{array}$ \\
\hline & & $\begin{array}{l}\text { Foundation/sheet phe-The } \\
\text { maximumpermissible length to } \\
\text { delwer by tuck }\end{array}$ & $\begin{array}{l}\text { The maximum permissble ple length } \\
\text { delvered by truck is } 20 \text { if. Superor } \\
\text { Constructon had to order the } 1 \text { th if pling in } \\
\text { wo pieces to accommodate delvery, but } \\
\text { payment can not be made for the splicing. }\end{array}$ \\
\hline
\end{tabular}

Figure 26: Lessons Learned for Foundation c 


\subsubsection{Lessons Learned-CONSTRUCTION}

In the following table the lessons learned for the construction are provided.

\section{1}

\begin{tabular}{|c|c|}
\hline Description & (1) ins tescoust lemed \\
\hline $\begin{array}{l}\text { Construction/Concrete Work- } \\
\text { Thrie-8eam Repair }\end{array}$ & $\begin{array}{l}\text { is is obvous that Thrie Beam will be } \\
\text { damaged by the traveling public during the } \\
\text { life of the project. State clearly in the plan } \\
\text { that the contractor s responsble for first } \\
500 \text { feet of repar, above the first soo feet of } \\
\text { repar =ooT should compensate him. }\end{array}$ \\
\hline $\begin{array}{l}\text { Construction/Concrete work- } \\
\text { Omission of the Condult in } \\
\text { Pedestran barrier wall by the } \\
\text { contractor }\end{array}$ & $\begin{array}{l}\text { Contractor should include the condut th the } \\
\text { odding process for the pedestrian barrier } \\
\text { wall }\end{array}$ \\
\hline \multirow[t]{2}{*}{$\begin{array}{l}\text { Construction/Concrete Work- } \\
\text { offerentmaterialused by the } \\
\text { contractor (bond breaker) }\end{array}$} & $\begin{array}{l}\text { is the OEPT.'s postion that the furnishing } \\
\text { and installaton of an approved material } \\
\text { bond breaker; is included in the contract } \\
\text { price which price shall be ful compensation } \\
\text { for all work specified and shall include all } \\
\text { materias and incidentals necessary to } \\
\text { complete the work. }\end{array}$ \\
\hline & $\begin{array}{l}\text { Specifications require that materials } \\
\text { proposed by the conteractor must be } \\
\text { submitted and aoproved by the DEPT. }\end{array}$ \\
\hline $\begin{array}{l}\text { Construction/Concrete Work- } \\
\text { Prestressed Beams-late payment }\end{array}$ & $\begin{array}{l}\text { It is the DEPT.'s responsibitity that the } \\
\text { payment for any item should be paid fuly } \\
\text { unless some changes occured by the } \\
\text { contractor. }\end{array}$ \\
\hline
\end{tabular}

Figure 27: Lessons Learned for Construction a 


\section{C1}

\begin{tabular}{|c|c|c|}
\hline $\begin{array}{l}\frac{1}{5} \\
3 \\
\frac{1}{4} \\
\frac{1}{0} \\
\end{array}$ & $\begin{array}{l}\text { Construction/Concrete Work- } \\
\text { Temporary Barrier-glare screen- } \\
\text { payment problem }\end{array}$ & $\begin{array}{l}\text { Make sure that the contract document } \\
\text { defines the scope of work to include } \\
\text { oroviding gare screen in conjunction with } \\
\text { the temporary barrer wall and also defines } \\
\text { hov the payment wh be made for the work }\end{array}$ \\
\hline \multirow{3}{*}{ 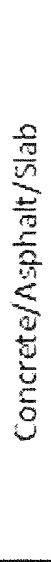 } & $\begin{array}{l}\text { Construction/Concrete/Asphat/ } \\
\text { slab-Removal of asphat materal }\end{array}$ & $\begin{array}{l}\text { Make sure that the contract document } \\
\text { defines the scope of work to remove asphat } \\
\text { material also defnes how the pament wh } \\
\text { oe made for the vork }\end{array}$ \\
\hline & $\begin{array}{l}\text { Construction/Concrete/Asphat// } \\
\text { Slab-Weather caused problem }\end{array}$ & $\begin{array}{l}\text { Make sure that the contract document } \\
\text { defines unforeseen condtions and aso } \\
\text { defines how the payment whe made for } \\
\text { this }\end{array}$ \\
\hline & $\begin{array}{l}\text { Construction/Concrete/Asphat/ } \\
\text { Slab-Quantity Change }\end{array}$ & $\begin{array}{l}\text { Make sure that the contract document } \\
\text { defines the quantites to be used and also } \\
\text { detines how the payment wh be made for } \\
\text { this }\end{array}$ \\
\hline $\begin{array}{l}\frac{y}{3} \\
\frac{3}{3} \\
\frac{y}{2} \\
\frac{y}{0} \\
\frac{5}{5}\end{array}$ & $\begin{array}{l}\text { Construction/Concrete Side Wak } \\
\text { Removal and repacement }\end{array}$ & 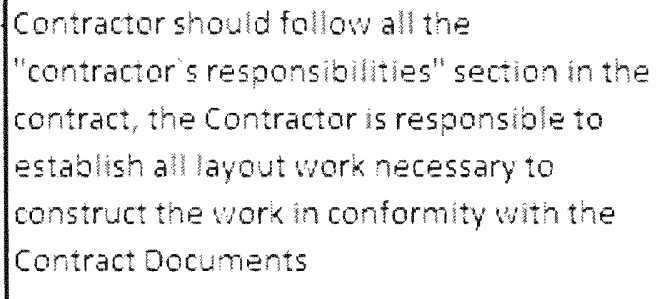 \\
\hline
\end{tabular}

Figure 28: Lessons Learned for Construction $b$ 


\begin{tabular}{|c|c|c|}
\hline 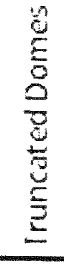 & $\begin{array}{l}\text { Construction/Truncated Domes- } \\
\text { Removal and replacement }\end{array}$ & $\begin{array}{l}\text { Wake sure that the contract document } \\
\text { defines unforeseen conditions and also } \\
\text { defines how the payment will be made for } \\
\text { this }\end{array}$ \\
\hline \multirow{4}{*}{$\begin{array}{l}\frac{2}{5} \\
3 \\
\frac{2}{5}\end{array}$} & $\begin{array}{l}\text { Construction/utily Work- } \\
\text { Differentinstallation system- } \\
\text { Ambiguous Plan }\end{array}$ & $\begin{array}{l}\text { If the installation of the utilty system } \\
\text { WATER HEATER has more than one options } \\
\text { to apply, should be made clear before } \\
\text { begnning the construction in the plan. }\end{array}$ \\
\hline & $\begin{array}{l}\text { Construction/Utily Work/Water } \\
\text { Rough-in Unclear statement to } \\
\text { supply landscape irrigation }\end{array}$ & $\begin{array}{l}\text { Make sure that the contract document } \\
\text { defines the scope of work to supply } \\
\text { andscape irrgat on also defines how the } \\
\text { bayment whll be made for the work }\end{array}$ \\
\hline & $\begin{array}{l}\text { Construction/Uthlty Work/Water } \\
\text { Rough-in removal of Water main }\end{array}$ & $\begin{array}{l}\text { The DEPT, and should Have early and } \\
\text { multple ste wists by regulatory enthies; } \\
\text { this proved extremely valuable from } \\
\text { information and cost estimating } \\
\text { perspectives and at the end provide correct } \\
\text { information to the people in the bidding } \\
\text { stage }\end{array}$ \\
\hline & $\begin{array}{l}\text { Construction/Utility Work/Gas } \\
\text { fough-in-delay problem }\end{array}$ & $\begin{array}{l}\text { Make sure to request additional tme } \\
\text { adiustment in time or fle a notice of delay } \\
\text { in time }\end{array}$ \\
\hline
\end{tabular}

Figure 29: Lessons Learned for Construction c 


\begin{tabular}{|c|c|c|}
\hline \multirow{3}{*}{$\begin{array}{l}\frac{1}{5} \\
\stackrel{5}{5} \\
\stackrel{2}{E}\end{array}$} & $\begin{array}{l}\text { Construction/Utilty Work/Gas } \\
\text { Rough-in-pipe problem }\end{array}$ & $\begin{array}{l}\text { Explain the problem encountered whth the } \\
\text { plpes /struck,rupture) clearly to the DEPT. to } \\
\text { get compensation }\end{array}$ \\
\hline & $\begin{array}{l}\text { Construction/utlity } \\
\text { Work/Electrical Rough-in-condut }\end{array}$ & $\begin{array}{l}\text { Wake sure that the contract document } \\
\text { defines the scope of work about condust } \\
\text { system and also defines how the paymen: } \\
\text { Whbe made for the work }\end{array}$ \\
\hline & $\begin{array}{l}\text { Construction/Utilty } \\
\text { WorkElectrical Rough-in-sealing }\end{array}$ & $\begin{array}{l}\text { Make sure that the contract document } \\
\text { defines the scope of work to seal the } \\
\text { electricaltems and also defines how the } \\
\text { payment will be made for the work }\end{array}$ \\
\hline \multirow[t]{2}{*}{ 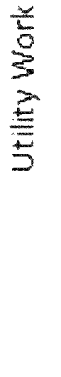 } & $\begin{array}{l}\text { Construction/Utilty } \\
\text { Work/Electrical Rough-in-lghting }\end{array}$ & $\begin{array}{l}\text { Make sure that the contract document } \\
\text { defines the scope of work about lighting and } \\
\text { also defines how the payment whll be made } \\
\text { for the work. }\end{array}$ \\
\hline & $\begin{array}{l}\text { Construction/Utily } \\
\text { Work/Electrical Rough-in- } \\
\text { replacement }\end{array}$ & $\begin{array}{l}\text { Make sure that the contract document } \\
\text { defines the scope of work to replace the } \\
\text { materials and as so defines how the payment } \\
\text { Whl be made for the work }\end{array}$ \\
\hline \multirow{2}{*}{ 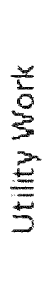 } & $\begin{array}{l}\text { Construction/utillty } \\
\text { Work/Electrical Rough-in-delay }\end{array}$ & $\begin{array}{l}\text { Make sure to request additional time } \\
\text { adustment in time or fle a notice of delay } \\
\text { in time }\end{array}$ \\
\hline & $\begin{array}{l}\text { Construction/Utilyty } \\
\text { Work/Speciality Rough-in- } \\
\text { (Phone system/delay }\end{array}$ & $\begin{array}{l}\text { All utilities around the ste should be } \\
\text { checked before starting the construction } \\
\text { because they may create utlity conflict. }\end{array}$ \\
\hline
\end{tabular}

Figure 30: Lessons Learned for Construction d 


\begin{tabular}{|c|c|c|}
\hline C & Description & Lessons leomed \\
\hline \multirow{5}{*}{ 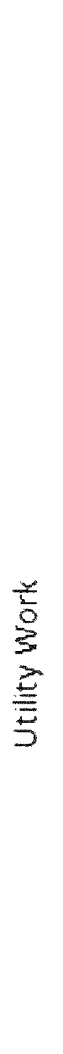 } & $\begin{array}{l}\text { Construction/Uthity } \\
\text { Work/Speciality Rough-in-lCable } \\
\text { system/-Plan error }\end{array}$ & $\begin{array}{l}\text { Make sure that the contract document is } \\
\text { explaned clearly }\end{array}$ \\
\hline & $\begin{array}{l}\text { Construction/Utility } \\
\text { Work/Relocation-delay }\end{array}$ & $\begin{array}{l}\text { Make sure to request additional the } \\
\text { adjustment in time or flle a notice of delay } \\
\text { in the }\end{array}$ \\
\hline & $\begin{array}{l}\text { Construction/Utility } \\
\text { Work/Relocation-missing items } \\
\text { in the plans }\end{array}$ & $\begin{array}{l}\text { Make sure to include all utility tems in the } \\
\text { plans }\end{array}$ \\
\hline & $\begin{array}{l}\text { Construction/Utily } \\
\text { Work/Conflict-damage to } \\
\text { existing utility systems }\end{array}$ & $\begin{array}{l}\text { The OEPT. and should Have early and } \\
\text { multiple site vists by regulatory entites: } \\
\text { this proved extremely valuable from } \\
\text { nformation and cost estmathg } \\
\text { perspectives and at the end provide correct } \\
\text { nformation to the people in the bidding } \\
\text { stage } \\
\text { Make sure the plans explain everything } \\
\text { accurately and horoughy about the site }\end{array}$ \\
\hline & $\begin{array}{l}\text { Construction/Utinty } \\
\text { Nork/Conflict-delay }\end{array}$ & $\begin{array}{l}\text { Make sure to request additional time } \\
\text { adjustment in time or fie a notice of delay } \\
\text { in time }\end{array}$ \\
\hline
\end{tabular}

Figure 31: Lessons Learned for Construction e 


\begin{tabular}{|c|c|c|}
\hline \multirow{4}{*}{ 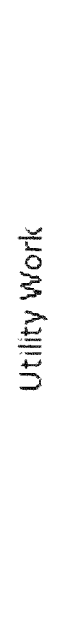 } & $\begin{array}{l}\text { Construction/Utility } \\
\text { Work/Conflict-third pary }\end{array}$ & $\begin{array}{l}\text { Is contractor's responsibllty to make the } \\
\text { ob done by the third pary (supplier, etc.). } \\
\text { is beyond the control of the contractor if } \\
\text { the material is defective. }\end{array}$ \\
\hline & $\begin{array}{l}\text { Construction/Utility } \\
\text { Work/Conflict-damage cost }\end{array}$ & $\begin{array}{l}\text { Is contractor's responsbility to keep the } \\
\text { dally records. in the absence of dally reports } \\
\text { it is difficult to assess the any damages }\end{array}$ \\
\hline & $\begin{array}{l}\text { Construction/Utility } \\
\text { Work/Conflict-unforeseen } \\
\text { condition }\end{array}$ & $\begin{array}{l}\text { Define clearly Unforeseen Work condtions } \\
\text { in the contractual documents. }\end{array}$ \\
\hline & $\begin{array}{l}\text { Construction/Utitity } \\
\text { Work/Drainage-deficiency in the } \\
\text { drainage system }\end{array}$ & $\begin{array}{l}\text { The appropriate materials should be } \\
\text { collected and provided as a proof for the } \\
\text { deficiencies }\end{array}$ \\
\hline \multirow{4}{*}{$\begin{array}{l}\frac{5}{5} \\
\frac{0}{5} \\
\frac{7}{E}\end{array}$} & $\begin{array}{l}\text { Construction/Insulation-timing } \\
\text { for application }\end{array}$ & $\begin{array}{l}\text { Make sure that the contract document } \\
\text { defines the thmg of coating clearlyand also } \\
\text { defines how the payment will be made for } \\
\text { this }\end{array}$ \\
\hline & $\begin{array}{l}\text { Construction/insulation-power } \\
\text { coating }\end{array}$ & $\begin{array}{l}\text { Make sure that the contract document } \\
\text { defines the scope of work to insulate the } \\
\text { materias and also defines how the payment } \\
\text { whl be made for the vork }\end{array}$ \\
\hline & Construction/Insulation-quantity & $\begin{array}{l}\text { Define the quantity of the materials to be } \\
\text { installed. }\end{array}$ \\
\hline & $\begin{array}{l}\text { Construction/insulation-unclear } \\
\text { statement in the contractual } \\
\text { documents }\end{array}$ & $\begin{array}{l}\text { Make sure that the contract document } \\
\text { defines the insulations materials to be used } \\
\text { and also defines how the payment will be } \\
\text { made for this }\end{array}$ \\
\hline
\end{tabular}

Figure 32: Lessons Learned for Construction $f$ 


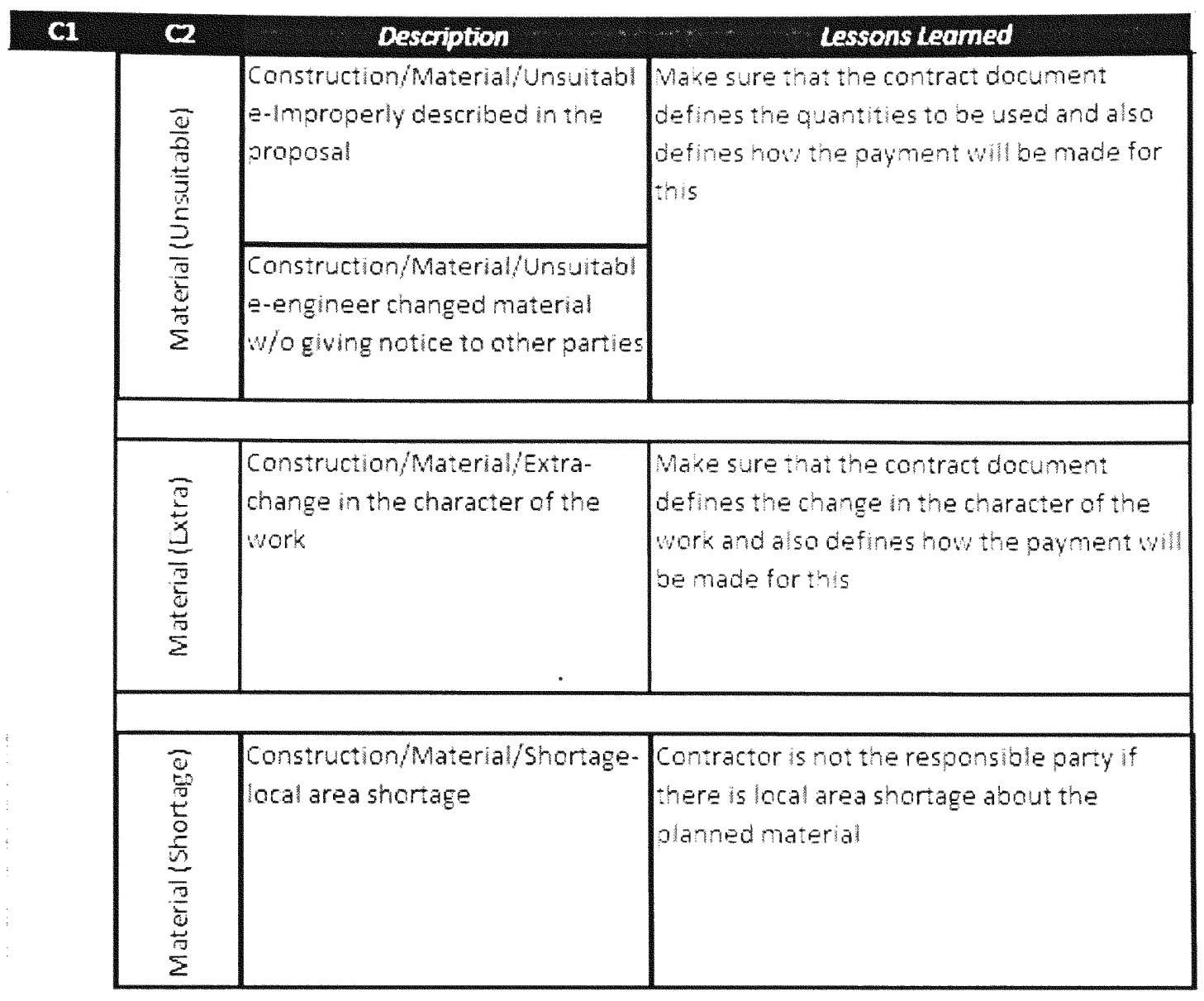

Figure 33: Lessons Learned for Construction g 


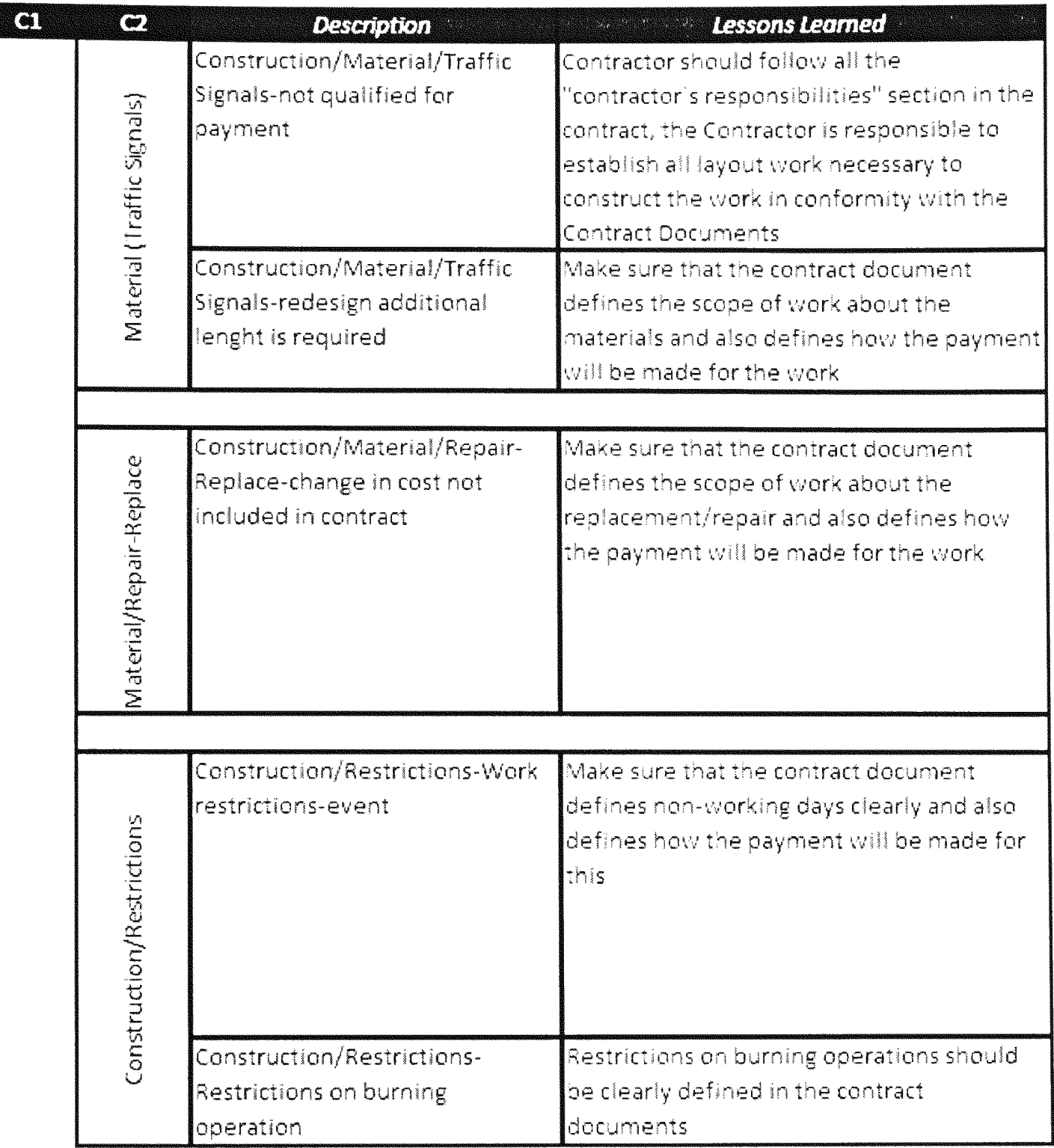

Figure 34: Lessons Learned for Construction $h$ 


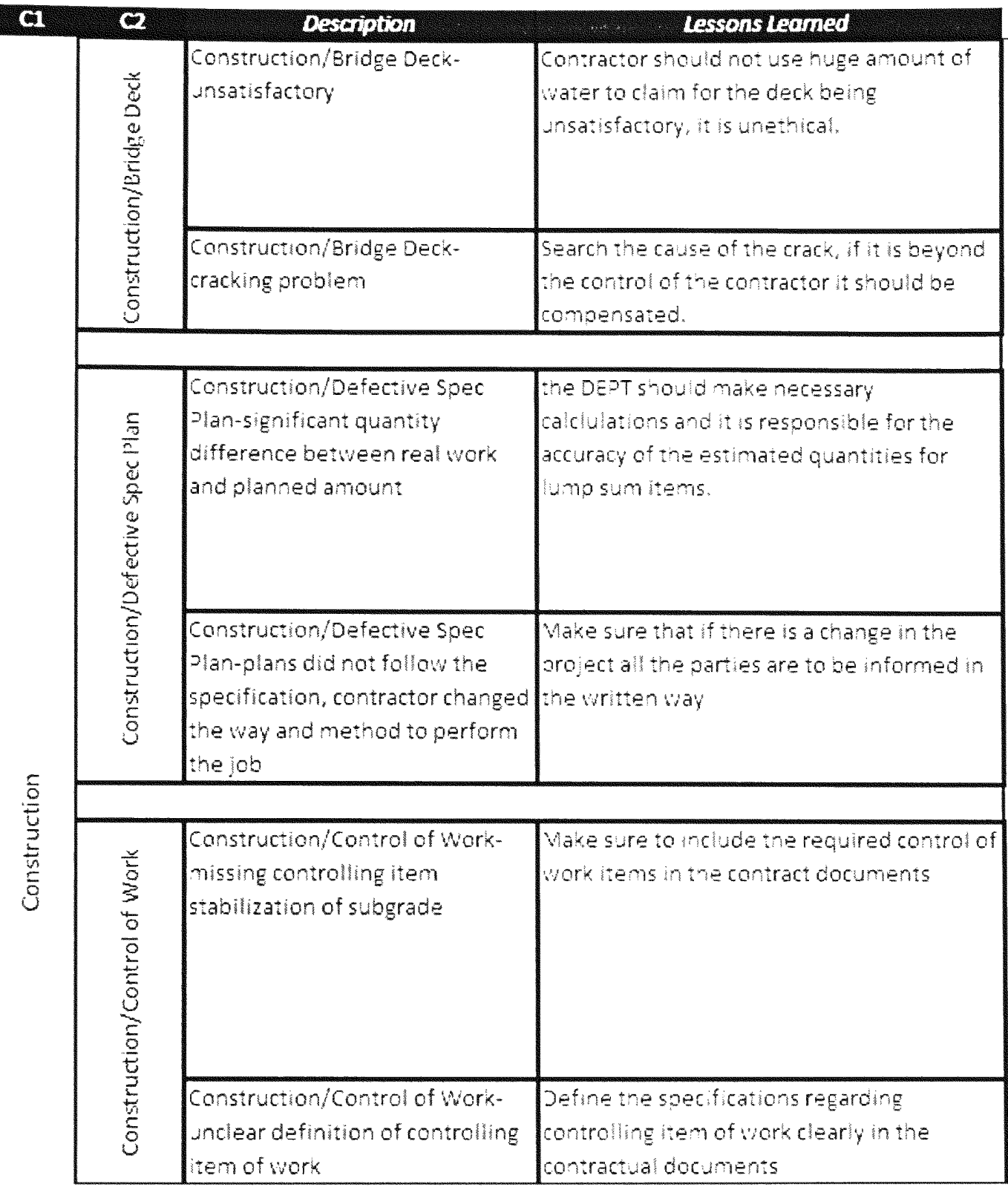

Figure 35: Lessons Learned for Construction i 


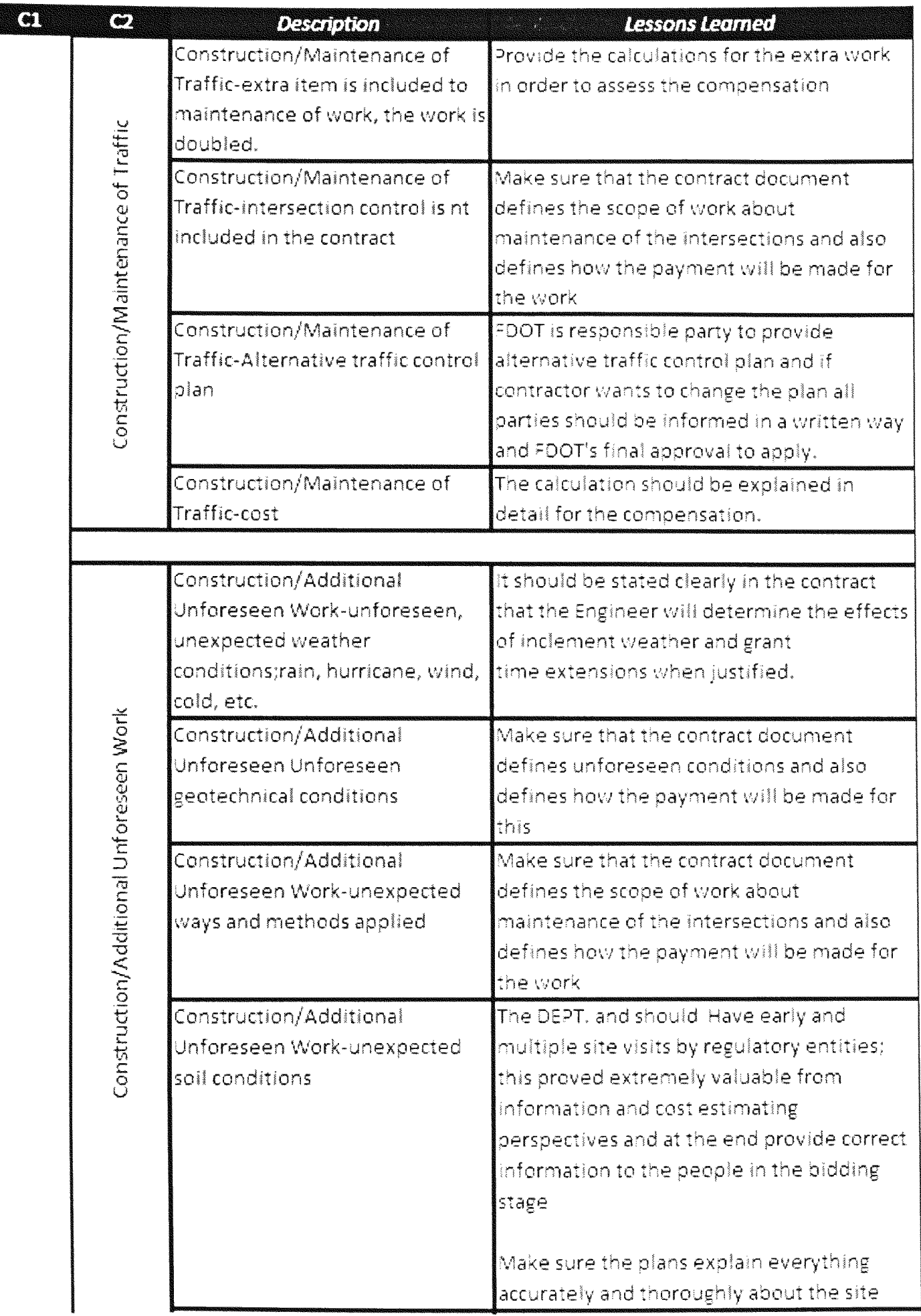

Figure 36: Lessons Learned for Construction $j$ 
Construction/Additional

unforeseen Work-unexpected

water table height

Construction/Additional

Unforeseen Work-unexpected

geotextile material coverage

Construction/Additional

Unforeseen Work-sanitary sever

alignment error,wrong hole due

to contractor's fault

Construction/Additional

Unforeseen Work-unexpected

bavement work

Construction/Additional

Unforeseen Work-umexpected

addition of work by contractor

Construction/Additional

unforeseen Work-unexpected

dewatering
Wake sure that the contract document

defines unforeseen conditions and also

defineshow the payment will be made for this

Make sure that the contract document

defines unforeseen conditions and aso

defines how the payment will be made for this

Wake sure that the contract document

defines unforeseen condtions and asso

defines hov the payment whl be made for thes

Arising ether from the execution or from

the nonexecution of the work. The

Department may, at its discretion, relmburse

Contractor is responsible for additional work

dome because of work is performed without aporovat

The DEPT. and should Have early and

mutiple ste ustis by regulatory entries:

this proved extremety waluable from

nformation and costestimating

oersoectues and at the end provide correct

information to the people in the bidding

stage

Make sure the plans exolain everything

accurately and horoughly about the site

Figure 37: Lessons Learned for Construction $k$ 


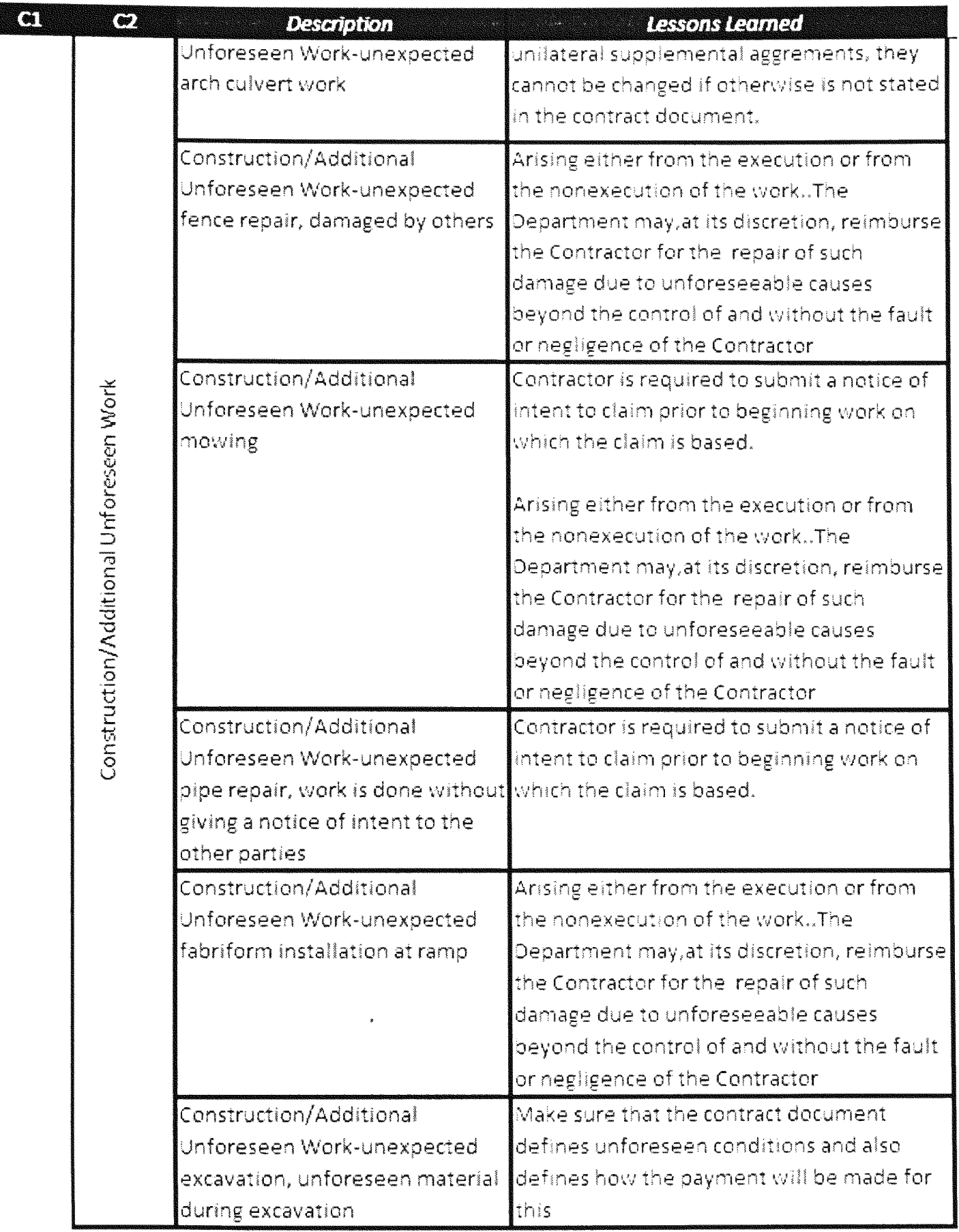

Figure 38: Lessons Learned for Construction l 


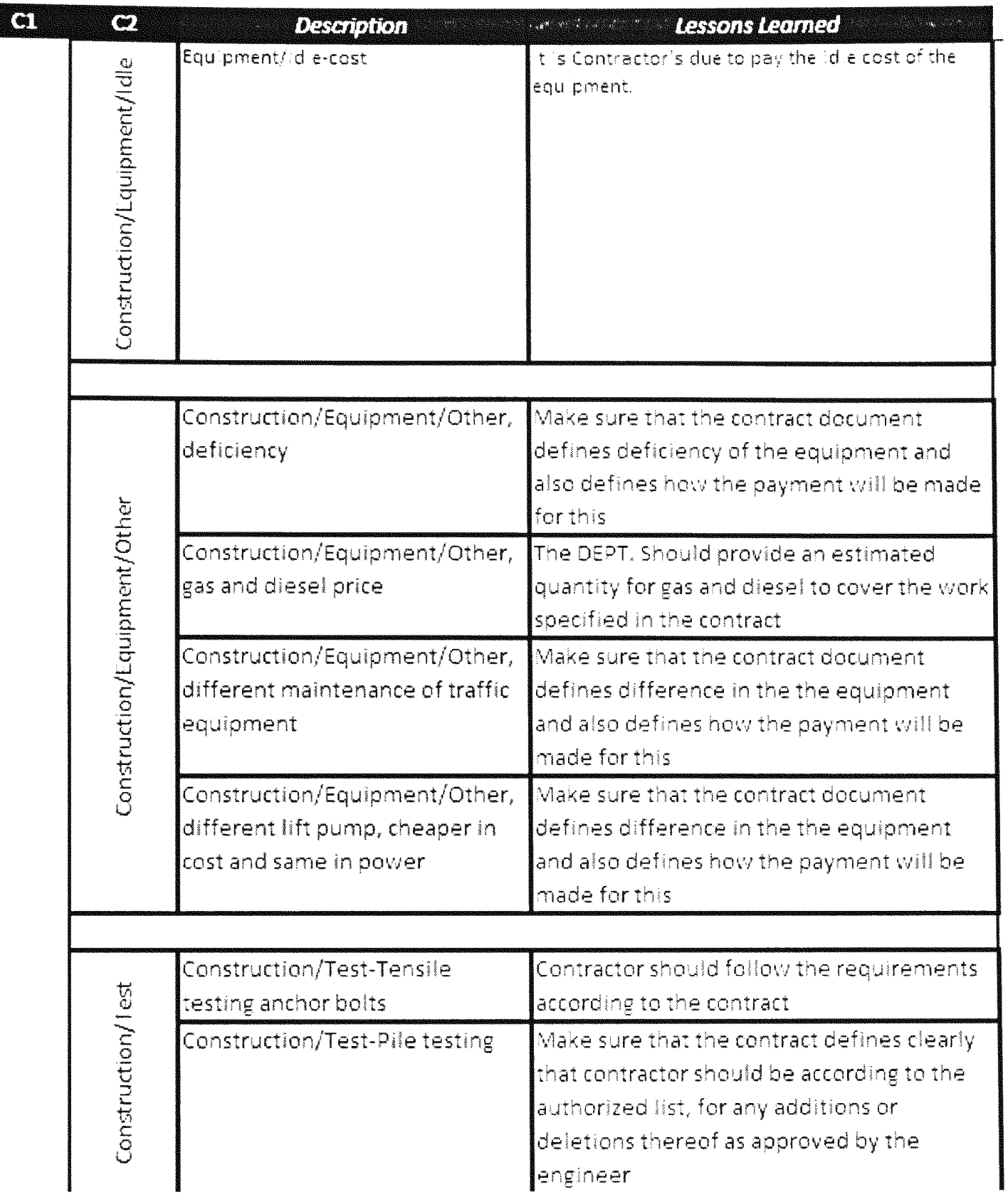

Figure 39: Lessons Learned for Construction $m$ 


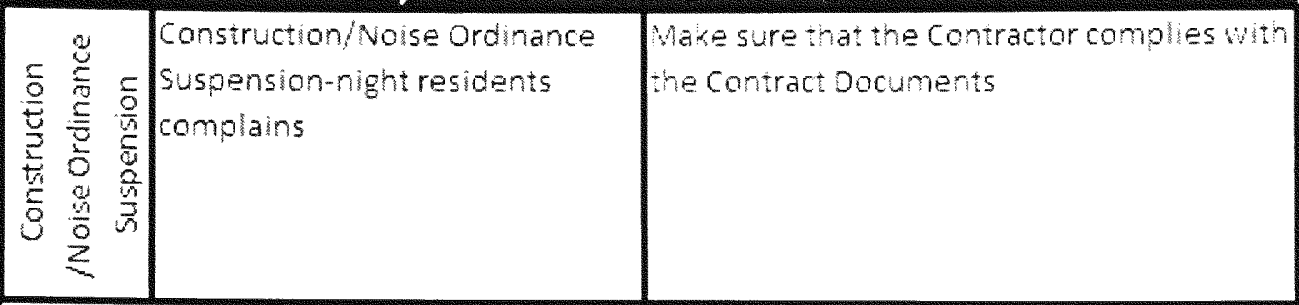

\begin{tabular}{|c|c|c|}
\hline \multirow{4}{*}{ 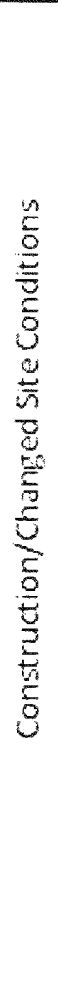 } & $\begin{array}{l}\text { Construction/Changed Site } \\
\text { Conditions-Differing site } \\
\text { conditions at pond, Enormous } \\
\text { amount of boulders than regular }\end{array}$ & $\begin{array}{l}\text { Make sure that the contract docunent } \\
\text { defines changed ste conditons and also } \\
\text { defines how the payment will be made for } \\
\text { this }\end{array}$ \\
\hline & $\begin{array}{l}\text { Construction/Changed Site } \\
\text { Conditions-Differing site } \\
\text { conditions, additional } \\
\text { dewatering than normal, } \\
\text { contractor falled to give a notice } \\
\text { of intent before beginning to } \\
\text { oerform the job }\end{array}$ & $\begin{array}{l}\text { Contractor is required to submit a notice of } \\
\text { ntent to clam prior to beginning work on } \\
\text { Which the clam is based. }\end{array}$ \\
\hline & $\begin{array}{l}\text { Construction/Changed site } \\
\text { Conditions-Differing site } \\
\text { conditions, change in the } \\
\text { ocation of the sanitary system }\end{array}$ & $\begin{array}{l}\text { Make sure that Contract documents explain } \\
\text { changed ste conditons as: conditions differ } \\
\text { materialy from what is ordinarily } \\
\text { encountered and recognized as inherent in } \\
\text { the work }\end{array}$ \\
\hline & $\begin{array}{l}\text { Construction/Changed site } \\
\text { Conditions-Differing site } \\
\text { conditions, lacking of limerock } \\
\text { for the base material. }\end{array}$ & $\begin{array}{l}\text { Make sure that Contract documents explan } \\
\text { the information regarding the compositon } \\
\text { of the existing base material on the road }\end{array}$ \\
\hline
\end{tabular}

Figure 40: Lessons Learned for Construction $n$ 


\begin{tabular}{|c|c|c|}
\hline \multirow{3}{*}{ 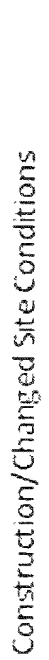 } & $\begin{array}{l}\text { Construction/Changed site } \\
\text { Conditions-Differing ste } \\
\text { conditions, lacking of stabilizing } \\
\text { materal }\end{array}$ & $\begin{array}{l}\text { Wake sure that Contract documents explam } \\
\text { changed ste conditons as: condrions differ } \\
\text { materialy from shat is ordinarily } \\
\text { encountered and recognized as inherent in } \\
\text { the vork }\end{array}$ \\
\hline & $\begin{array}{l}\text { Changed site condition-soll } \\
\text { condtions, contract plans greaty } \\
\text { differ from what was actually } \\
\text { found during the excavation of } \\
\text { sond. }\end{array}$ & $\begin{array}{l}\text { Is both the contractor's and fooT's } \\
\text { responsblity to montor the work and } \\
\text { changes. }\end{array}$ \\
\hline & $\begin{array}{l}\text { Construction/Changed site } \\
\text { condition-effects of high water }\end{array}$ & $\begin{array}{l}\text { Wake sure that Contract documents explain } \\
\text { changed site condtons as: conditions differ } \\
\text { materaly from shat s ordinarily } \\
\text { oncountered and recognzed as inherent in } \\
\text { the work }\end{array}$ \\
\hline \multirow{4}{*}{ 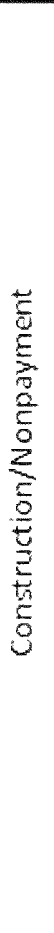 } & $\begin{array}{l}\text { Constuction/Nonpayment,hgh } \\
\text { mastlighting, missing pay item in } \\
\text { the plans }\end{array}$ & $\begin{array}{l}\text { Make sure that the contract documents } \\
\text { include pay tems for the all work that are } \\
\text { gong to oe done in the site and abo make } \\
\text { sure these pay ivems to be pad fully uness } \\
\text { otherwse stated due to some condtons. }\end{array}$ \\
\hline & $\begin{array}{l}\text { Construction/ Nonpayment,cond } \\
\text { ut, missing pay ltem in the plans }\end{array}$ & 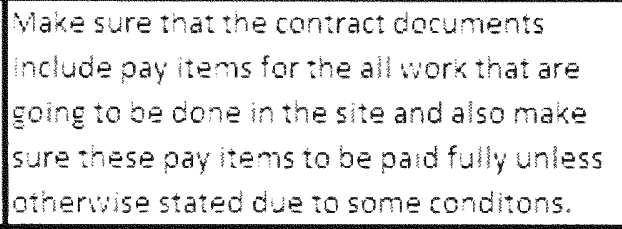 \\
\hline & $\begin{array}{l}\text { Construction/Nonpayment,frenc } \\
\text { drain missing payitemin the } \\
\text { olans }\end{array}$ & $\begin{array}{l}\text { Wake sure that the contract documents } \\
\text { holude pay tems for the all vork that are } \\
\text { soing to be done in the ste and alsomake } \\
\text { sure these pay items to be pad fuly uniess } \\
\text { otheryse stated due to some conduons. }\end{array}$ \\
\hline & $\begin{array}{l}\text { Construction/Nonpayment,partia } \\
\text { payment for the completed } \\
\text { vorktem }\end{array}$ & $\begin{array}{l}\text { Make sure that the contract documents } \\
\text { mclude paytems for the al work that are } \\
\text { gong to be done m the ste and also make } \\
\text { sure hese pay tems to be pald fuly unless } \\
\text { othervise stated due to some condtons. }\end{array}$ \\
\hline 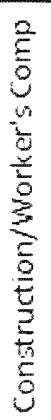 & $\begin{array}{l}\text { Construction/Worker's Comp- } \\
\text { increase, Decrease or Ateration } \\
\text { in the Work, Escalated Workers } \\
\text { Compensation Rates }\end{array}$ & 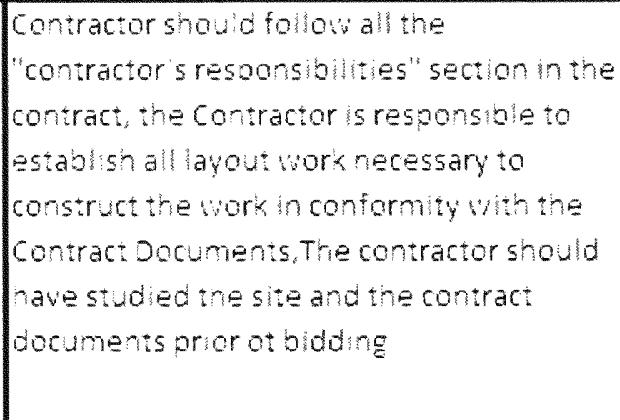 \\
\hline
\end{tabular}

Figure 41: Lessons Learned for Construction o 


\subsubsection{Lessons Learned-LAND SCAPE}

In the following table the lessons learned for the landscaping are provided.

\begin{tabular}{|c|c|c|c|}
\hline C.1 & 2 & Desangion & 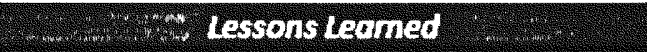 \\
\hline \multirow[b]{2}{*}{$\frac{\frac{0}{2}}{\frac{D}{0}}$} & \multirow{5}{*}{$\frac{3}{3}$} & $\begin{array}{l}\text { Landscaping/Oriveway-Contract } \\
\text { pay items did notinclude } \\
\text { mantaning commercialmateral } \\
\text { for driveway mantenance }\end{array}$ & $\begin{array}{l}\text { Maka sure that the contract documents } \\
\text { mclude pay tems for the all work that are } \\
\text { gong to be done in the site and also make } \\
\text { sure these pay items to be paid fuly uness } \\
\text { otherwse stated due to some conditons. }\end{array}$ \\
\hline & & $\begin{array}{l}\text { Landscaping/orveway-Asphalt } \\
\text { drveway delay.sidewak } \\
\text { elevations not being correcty } \\
\text { provided in the plans }\end{array}$ & $\begin{array}{l}\text { Make sure that Contract documents provide } \\
\text { correcty sidevakelevations }\end{array}$ \\
\hline \multirow{2}{*}{ 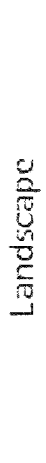 } & & $\begin{array}{l}\text { Landscaping/orveway-drveway } \\
\text { materia, contractor falled to gue } \\
\text { a notice of intent before } \\
\text { beginning the work }\end{array}$ & $\begin{array}{l}\text { Contractor s required to submit a notice of } \\
\text { intent to chimprior to beginning vork on } \\
\text { Which the clam is based. }\end{array}$ \\
\hline & & $\begin{array}{l}\text { Landscapinglorveway-Drvevay } \\
\text { fence, oue to shope of the } \\
\text { drveways extended onto the } \\
\text { adjacent property temporariv } \\
\text { relocation and then permanent } \\
\text { reinstall the roht of way work } \\
\text { vas required }\end{array}$ & $\begin{array}{l}\text { Make sure that the contract document } \\
\text { defines the scope of work about drweway } \\
\text { and a so defhes how the payment wh be } \\
\text { made for he vork }\end{array}$ \\
\hline$\frac{\mathscr{c}}{\tilde{Z}}$ & & $\begin{array}{l}\text { Landscaping/orveway-Drveway } \\
\text { extra work is added, Foot } \\
\text { directed contractor to perform } \\
\text { the work }\end{array}$ & $\begin{array}{l}\text { =o is in the charge for the vork done by } \\
\text { the contractor because FoT drected } \\
\text { contractor to perform }\end{array}$ \\
\hline
\end{tabular}

Figure 42: Lessons Learned for Land Scape a 


\begin{tabular}{|c|c|c|c|}
\hline & 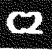 & Descivition & 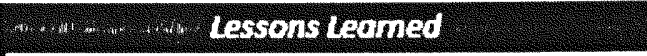 \\
\hline$\frac{\mathscr{Z}}{\mathscr{E}}$ & \multirow{4}{*}{ 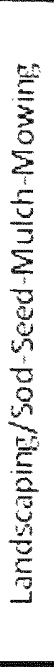 } & $\begin{array}{l}\text { Landscaping/Sod-Seed-Mulch- } \\
\text { Mowing-quantity,changed } \\
\text { Character of work }\end{array}$ & $\begin{array}{l}\text { Engineer determmes that the character of } \\
\text { hne work as altered difers materlaly in } \\
\text { kind or nature. }\end{array}$ \\
\hline \multirow{3}{*}{$\begin{array}{l}0 \\
0 \\
\frac{O}{0} \\
\frac{0}{0}\end{array}$} & & $\begin{array}{l}\text { Landscaping Sod-Seed-Much- } \\
\text { Mowing-quantity,changed } \\
\text { characier of work Hay bale } \\
\text { quantity }\end{array}$ & $\begin{array}{l}\text { combactor should at hs expense provide } \\
\text { routine mantenance of permanent and } \\
\text { cemporary erosion controlfeatures unt the } \\
\text { orofect is coms eted and accepted }\end{array}$ \\
\hline & & $\begin{array}{l}\text { Landscaplng/Sod-Seed-Mukch- } \\
\text { Wowing-seeding and mulching }\end{array}$ & $\begin{array}{l}\text { Contractor s required to submit a notice of } \\
\text { intent to clamprimor to beginning work on } \\
\text { which the clamis based. }\end{array}$ \\
\hline & & $\begin{array}{l}\text { landscaping/Sod-Seed-Mulch- } \\
\text { Mowing-sodding }\end{array}$ & $\begin{array}{l}\text { Make sure to out the tem to the contract } \\
\text { saying that contractor mantains the sodded } \\
\text { areas in a satisfactory condition und final } \\
\text { acceptance of the project }\end{array}$ \\
\hline$\frac{0}{8}$ & $\begin{array}{l}\frac{2}{5} \\
0 \\
\frac{3}{5} \\
\frac{0}{3} \\
\frac{3}{3} \\
\frac{3}{3} \\
3\end{array}$ & $\begin{array}{l}\text { Landscaping/Pond-Additional } \\
\text { skimmer for the pond }\end{array}$ & $\begin{array}{l}\text { Wake sure that the contract document } \\
\text { defines the scope of work and also defmes } \\
\text { now the payment wh be made for the work }\end{array}$ \\
\hline$\frac{0}{0}$ & 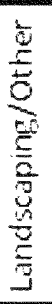 & $\begin{array}{l}\text { andscapinglother- } \\
\text { Unavalabinty of landscape trees, } \\
\text { Area-vide shoratge of plants } \\
\text { stated in the plan }\end{array}$ & $\begin{array}{l}\text { Contractor is not the responsible pary if } \\
\text { there is local area shortage about the } \\
\text { planned materal }\end{array}$ \\
\hline
\end{tabular}

Figure 43: Lessons Learned for Land Scape b 


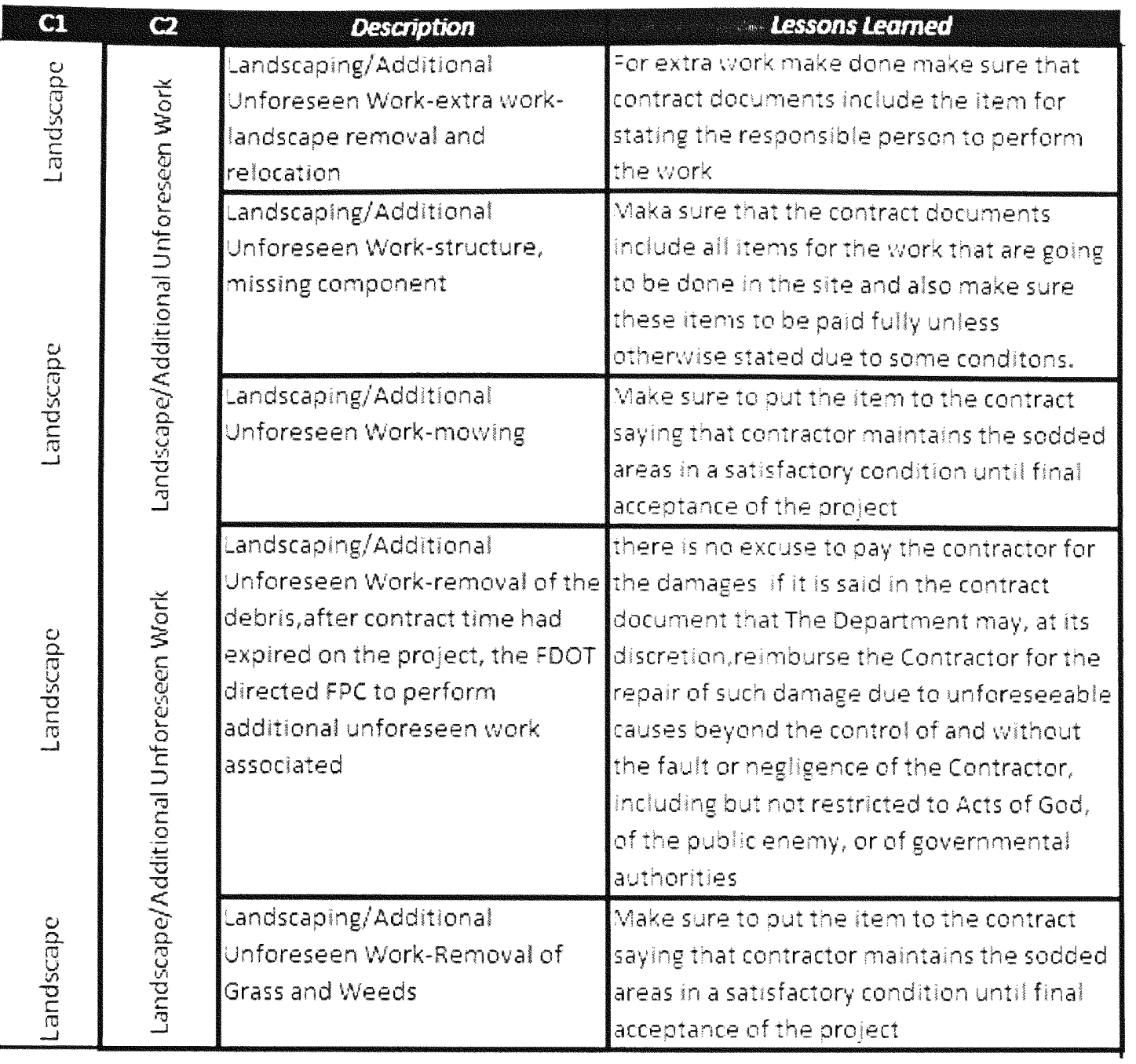

Figure 44: Lessons Learned for Land Scape c

\subsubsection{Lessons Learned-OTHER}

In the following table the lessons learned for the disputes that can not be placed under one of the categories mentioned above are provided. 


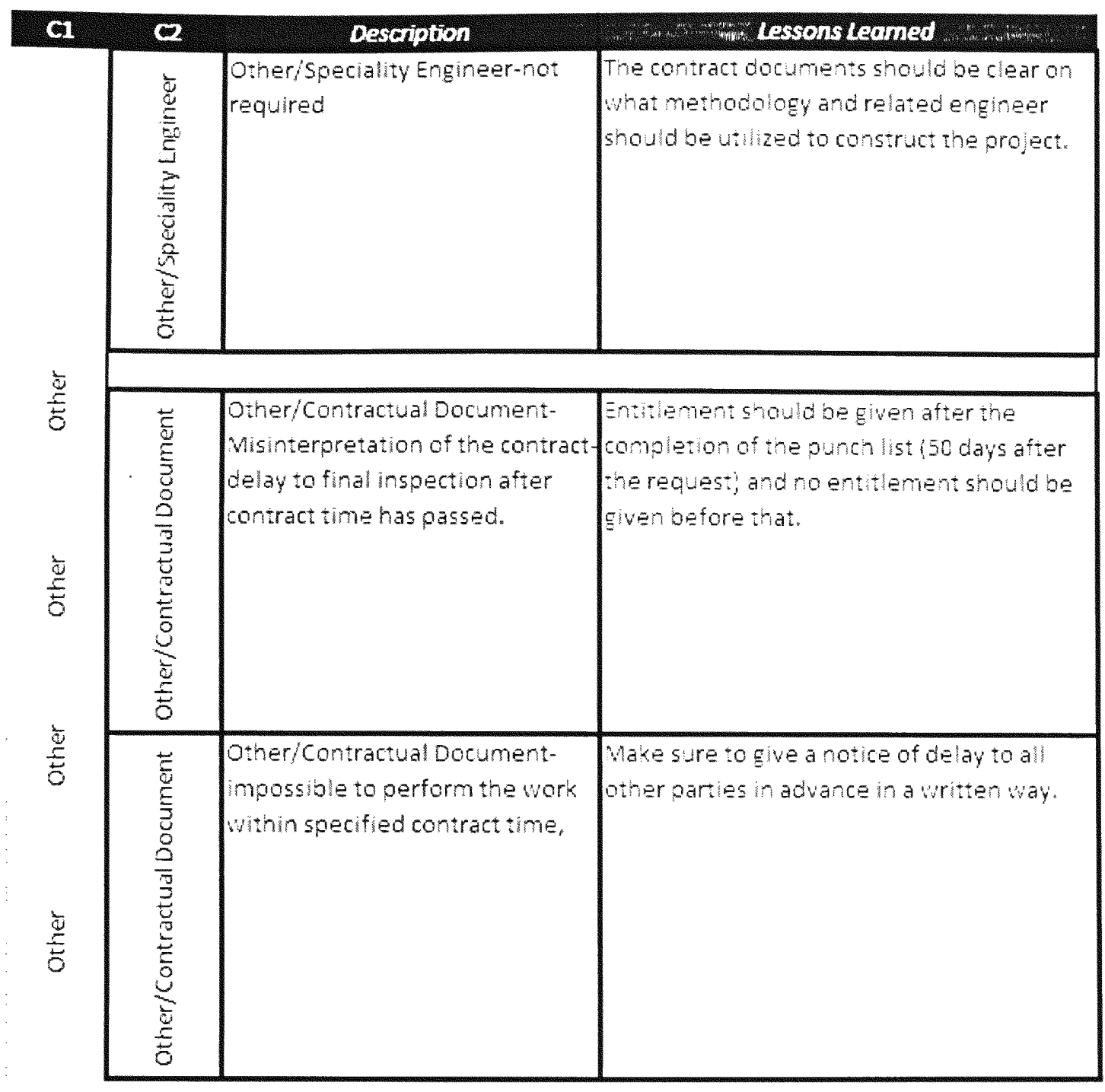

Figure 45: Lessons Learned for Other a 


\begin{tabular}{|c|c|c|c|}
\hline C1 & C2 & Description & 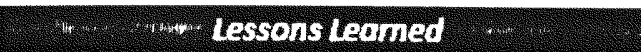 \\
\hline$\frac{\grave{\Phi}}{5}$ & 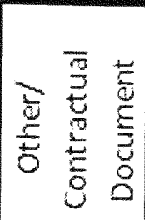 & $\begin{array}{l}\text { Other/Contractual Document- } \\
\text { missing contract provision }\end{array}$ & $\begin{array}{l}\text { It is foot's responsibutites to use and } \\
\text { follow the contract provisions. By deleting } \\
\text { the contract provisions fooT can not avold } \\
\text { the responsblities. }\end{array}$ \\
\hline$\frac{\bar{y}}{5}$ & 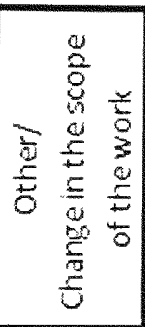 & Other/Change in Scope of Work & $\begin{array}{l}\text { Make sure that the contract document } \\
\text { defines the scope of work aso defines hov } \\
\text { the payment will be made for this }\end{array}$ \\
\hline & 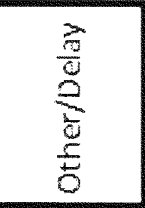 & $\begin{array}{l}\text { Other/Delay-denial of time } \\
\text { extension which resulted in } \\
\text { delay of the project }\end{array}$ & $\begin{array}{l}\text { Make sure that the contract document } \\
\text { defmes the delay of work also defines how } \\
\text { the payment will be made for this }\end{array}$ \\
\hline$\frac{5}{5}$ & $\begin{array}{l}\frac{E}{2} \\
\frac{0}{5} \\
\frac{1}{2} \\
\frac{2}{2} \\
\frac{5}{5} \\
\frac{5}{0}\end{array}$ & $\begin{array}{l}\text { Other/Fire Hydrant- } \\
\text { relocation, fire hydrant had to be } \\
\text { relocated so that planned work } \\
\text { could be accomplished }\end{array}$ & $\begin{array}{l}\text { Make sure to request additional time } \\
\text { adustment in time or flie a notice of delay } \\
\text { in time }\end{array}$ \\
\hline
\end{tabular}

Figure 46: Lessons Learned for Other b 


\begin{tabular}{|c|c|c|c|}
\hline C1. & Q & essonpton & lessous labluled \\
\hline$\frac{E}{5}$ & 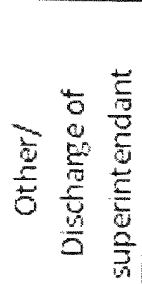 & $\begin{array}{l}\text { Other/Oischarge of } \\
\text { superintendant-oEPT.'s } \\
\text { discharge: Contractor's } \\
\text { superintendent from the project, } \\
\text { superintendant was unfainful } \\
\text { while getting the permits }\end{array}$ & $\begin{array}{l}\text { Wake sure that superintendant acts whin } \\
\text { the contract anguage otherwise OEPT. has } \\
\text { the rght to remove the personnel from the } \\
\text { oroiect for the reasons in the } \\
\text { speciofictons. }\end{array}$ \\
\hline$\frac{5}{5}$ & $\frac{\frac{9}{4}}{\frac{9}{2}}$ & $\begin{array}{l}\text { Contractor requested } \\
\text { compensable days at the rate of } \\
5 x \text { for overhead expenses }\end{array}$ & $\begin{array}{l}\text { Wake sure that in the contract there is no } \\
\text { condition sayng precuding the Contractor } \\
\text { from seeking addtional compensation whth } \\
\text { supplementa agreement }\end{array}$ \\
\hline$\frac{\overline{2}}{E}$ & 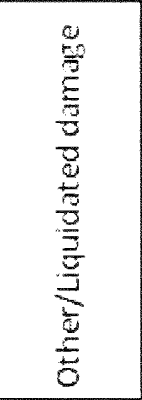 & $\begin{array}{l}\text { Other/Liquidated damage. } \\
\text { hquidated savings, contractor } \\
\text { completed the vork before the } \\
\text { contract time so he is elghble for } \\
\text { lquidated savings because was } \\
\text { agreed on the contract } \\
\text { documents }\end{array}$ & $\begin{array}{l}\text { Make sure that in the contract here is no } \\
\text { condtion sayng precluding he contractor } \\
\text { from seeking iquidated savings in case of } \\
\text { eary completion of the project }\end{array}$ \\
\hline
\end{tabular}

Figure 47: Lessons Learned for Other $c$ 


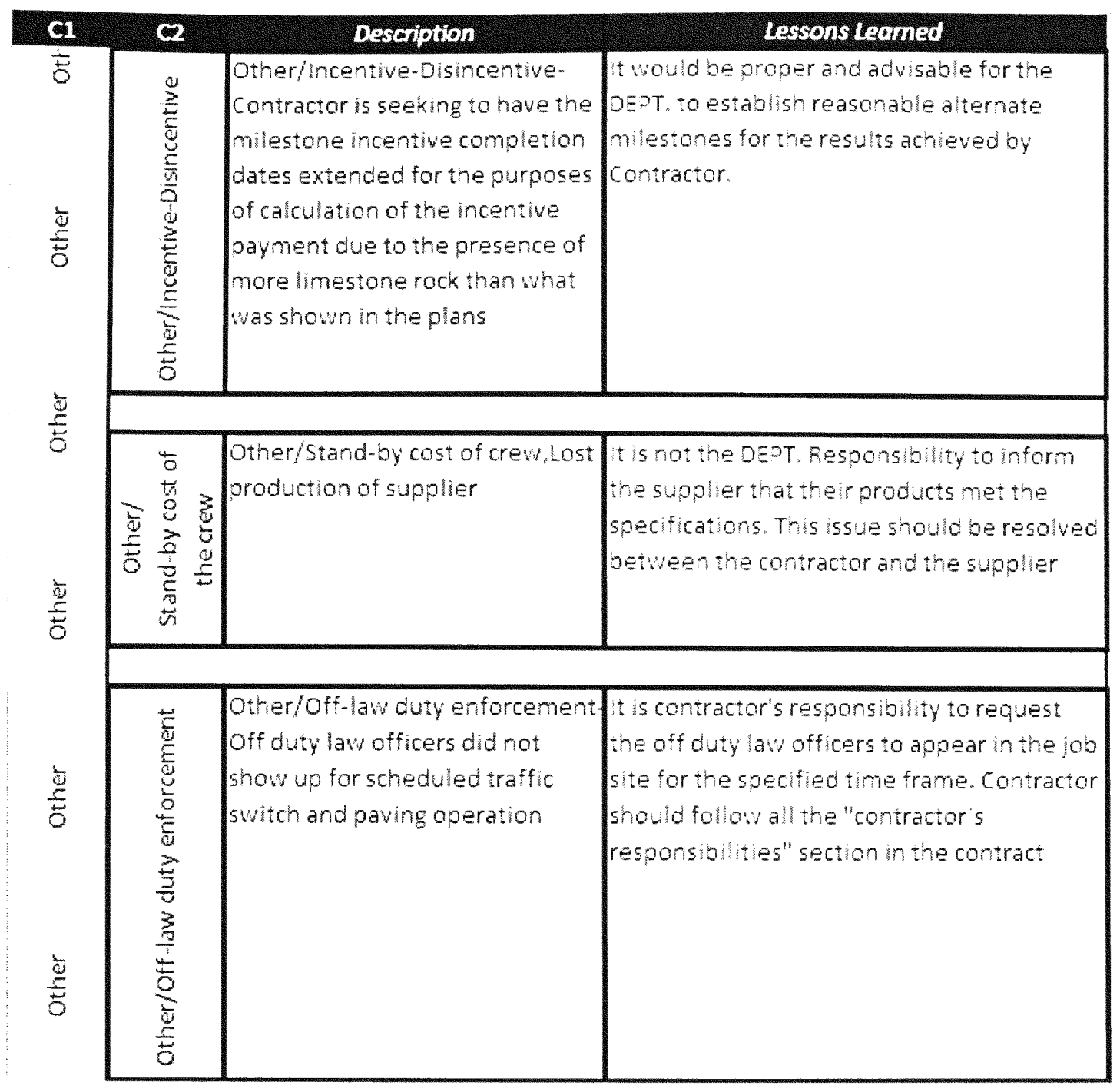

Figure 48: Lessons Learned for Other d 


\begin{tabular}{|c|c|c|c|}
\hline a) & $\infty$ & Desorition & tessons leomed \\
\hline 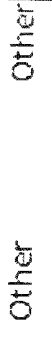 & 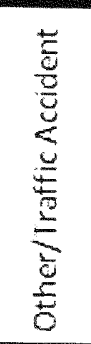 & $\begin{array}{l}\text { Other/Traffic Accident- } \\
\text { Unforeseen traffic accident took } \\
\text { place in the job site. }\end{array}$ & $\begin{array}{l}\text { Make sure to state clearly in the contractual } \\
\text { documents that accident is under the } \\
\text { responsblity of the contractor to be } \\
\text { resolved }\end{array}$ \\
\hline$\frac{\Phi}{\Phi}$ & 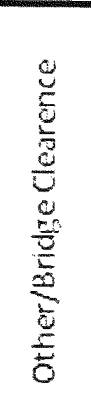 & $\begin{array}{l}\text { Other/sridge clearence-it was } \\
\text { discovered that the requred } \\
\text { chearance between the columns } \\
\text { of this bridge vas not avalable. } \\
\text { Writen prelminary notice is } \\
\text { required within specified } \\
\text { (i.e:ten/ calendar days } \\
\text { after commencement of a delay. }\end{array}$ & $\begin{array}{l}\text { Wake sure the preliminary notce is given } \\
\text { Wthin the soectied the gap by the } \\
\text { conbractor =alure to comply results in } \\
\text { Waver of entitlement }\end{array}$ \\
\hline$\frac{5}{5}$ & 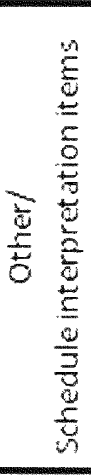 & $\begin{array}{l}\text { Other/schedule interpretation } \\
\text { items-contractor wants to know } \\
\text { what type of items interpret the } \\
\text { schedule of a prosect }\end{array}$ & 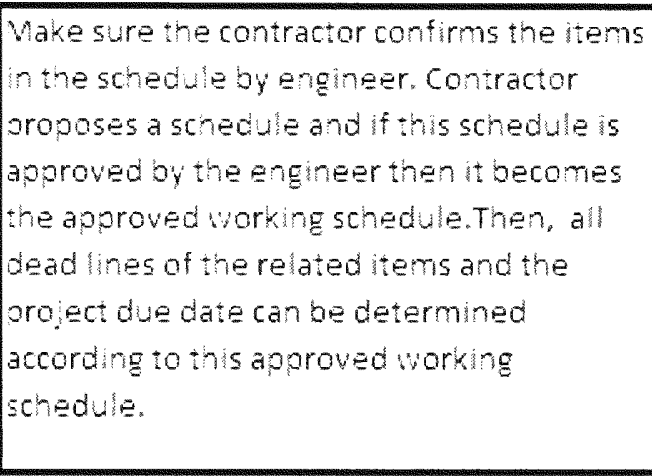 \\
\hline
\end{tabular}

Figure 49: Lessons Learned for Other e 


\begin{tabular}{|c|c|c|c|}
\hline C1 & 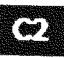 & Description & - Lessons Leamed \\
\hline$\frac{\grave{y}}{5}$ & $\begin{array}{l}\frac{E}{5} \\
\frac{5}{0} \\
\frac{5}{5} \\
\frac{5}{0} \\
\frac{E}{5}\end{array}$ & $\begin{array}{l}\text { Other/Vandalism, vandalism was } \\
\text { a foreseen case in part of the } \\
\text { dade county where the } \\
\text { construction was being held. }\end{array}$ & $\begin{array}{l}\text { tis contractor's responsibility to take } \\
\text { precautions to avold this kind of problems in } \\
\text { the job ste. }\end{array}$ \\
\hline 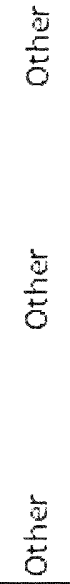 & 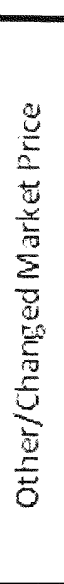 & $\begin{array}{l}\text { Other/Changed Market price, } \\
\text { delay beyond the control of the } \\
\text { contractor, OEpT. delayed the } \\
\text { completion of design } \\
\text { consequently putting the bidding } \\
\text { period into a very unfavorable } \\
\text { bidding climate due to the } \\
\text { hurricanes and resuting work } \\
\text { loads. Material prices increased } \\
\text { during this delay period due, in } \\
\text { part, to overseas market } \\
\text { influences. }\end{array}$ & $\begin{array}{l}\text { t is contractoris responsiblly to be aware } \\
\text { of the market conditions and bid } \\
\text { accordingly. }\end{array}$ \\
\hline
\end{tabular}

Figure 27.6: Lessons Learned for Other $f$

\subsection{Results and Recommendation}

Based on the developed lessons learned, users can find lessons learned for similar cases compared to their problems. There are some repeated lessons learned thorough out the document, however, these are the most common mistakes or causes that disputes are arisen from. Since each lesson has its own cause, it will be easier for the parties to look for a lessons learned at a specific stage of project life cycle. For each stage in the project duration, special headings were developed so that users can check for lessons learned for the new cases. 


\section{SUMMARY AND RECOMMENDATIONS}

\subsection{Introduction}

This is the last chapter of the study which will conclude all the study that had been carried out. This section consisted of the literature review and findings of the study that carried out in chapters 3 , and 4 .

\subsection{Summary}

From the research, in general terms, recurring mistakes on big projects are costly among parties involved in construction projects (R.B Hellard (1987), D.A Langford (1992), M. Smith (1992), and S.O. Cheung and C.H. Suen (2002)).

Disputes that arise from parties are mainly due to unforeseen conditions, schedule delays, as well as changes and variation in material. To avoid these disputes that occurred in the past, there are some lessons learned. However, many of the lessons learned are under-utilized within transportation industry or mistakenly applied. There are many problems faced by practitioners: Many of the existing lessons learned (a) theoretical, (b) $\underline{\text { not readily useable, and (c) their reliability and benefits are not clear. }}$

So, a new lessons learned document which is utilized and readily useable was created to help industry benefit lessons learned much easier. First, to develop this document, analysis of the existing disputes in DRB database was to be conducted district by district. The characteristics of the disputes in the database were developed by examining the previous studies done by researchers and disputes in the database. The characteristics can be listed as follows; (1) materials, (2) quality, (3) safety, (4) plans and specifications, (5) construction methods, (6) equipment, (7) third party hindrance, (8) quantity variation, (9) unforeseen conditions, and (10) permit. According to the analysis, 
top three characteristics of disputes encountered in DRB database out of 262 disputes are;

(i) unforeseen conditions with sixty seven disputes (\%26), (ii) quantity variation with fifty eight disputes (\%22), and plans \& specifications with forty three disputes (\%16).

Then, the disputes were analyzed according to the results of the cases. Out of 262 disputes only one dispute was submitted to DRB by FDOT, the remaining 261 disputes were submitted by contractors. When the outcomes of the cases are compared, there is not a huge difference in numbers. Out of 262 disputes, the contractors won 119 (\% 45.42) times, while FDOT won 133 (\% 50.76) times. Moreover, ten times (\% 3.82) the disputes were concluded in negotiation.

Next, monetary value and time value of the disputes were discussed. Since each dispute did not have monetary and/or time value, most of the them were categorized as N/A. Monetary value of the disputes revealed that 188 disputes $(\% 72)$ did not have any monetary specified. The remaining seventy four reports were placed under the ranges from $\$ 0-\$ 49,999$ to $\$ 150,000 \&$ above. On the other hand, time value of the disputes shown that 185 disputes (\%71) did not have a specific time value. The remaining seventy seven disputes are located under the ranges from 0-25 days to 76 day $\&$ above.

After analysis of the disputes in terms of characteristics, monetary value, time value, and winner/loser, next step was to develop lessons learned. To develop a more utilized, user friendly lessons learned documents, it was thought if each lesson could be placed under one specific project stage, it would be easier to look for it. Project stages can be listed as follows; permit, site work, foundation, construction, landscaping, and other. Each stage has its own sub-stage or sub-stages. Out of 262 disputes, 153 disputes were 
placed under the construction stage (\%58). The information about the number of disputes for each stage was shown in detail.

Based on the developed lessons learned, in general it is aimed that users can look for lessons in the document to avoid similar problems occurred in the past. Instead of general lessons learned document, project stages are used as a guidance to help users locate lessons learned more specifically and easily. During the project stages, problems can be pinpointed and suitable lessons can be checked in the document. Moreover, lessons learned document can be used to see in which stage of project; more attention is needed to be paid. So that recurrence of the positive outcomes is supported while recurrence of negative outcomes is avoided.

\subsection{Research Contributions}

The objective of this thesis was to develop a lessons learned document to avoid recurrence of negative outcomes and to promote recurrence of positive outcomes for FDOT projects.

This research contributed to the body of knowledge lessons learned document for FDOT projects. The document focused on all project stages, related activities during a project building phase from the pre-construction to the post-construction phase. The content of the document was a compilation of suggestions, recommendations by different DRB board members.

The lessons learned document can be used in several facets. First of all, parties involved in construction project can use the document to identify how to avoid possible future disputes. Secondly, parties that experienced the problems during the project can use the document as a reference guide for resolving dispute. 


\section{REFERENCES}

Ameer Ali (2005) A "Construction Industry Payment and Adjudication Act" Reducing Payment -Default and Increasing Dispute Resolution Efficiency.

Amjad Waheeda, Hojjat Adelib Case-based reasoning in steel bridge engineering, (2004).

Ashley, K., and Rissland, E. (1987), "Compare and contrast a test of expertise. In Proceedings of the Sixth Annual National Conference on Artificial Intelligence", 273,284 Menlo Park, CA: Morgan Kaufmann Publishers, Inc.

Ashley, K. (1990), "Modeling legal argument: reasoning with cases and hypotheticals", Cambridge: MIT Press.

A. Hewit, S. Page, M. Davenport and, (1991) Agricultural trade liberalization in the Uruguay Round: implications for developing countries. New York, UN.

Amir, Hossein Mahvi; Dariush, Naghipour; Forugh, Vaezi and Shahrokh, Nazmara (2005), Tea waste as an adsorbent for heavy metal removal from industrial wastewaters. American Journal of Applied Sciences, Volume 2, Issue 1, p. 372-375.

Bain, W. Judge. In Riesbeck, C., and Schank, R., (Eds.), "Inside Case-Based Reasoning. Lawrence Erlbaum". Chapter 4, 93 \{140.\}, Hillsdale, NJ: Lawrence Erlbaum Associates, Inc., Publishers.

Carlos H. Caldas, G. Edward Gibson, Jr., and Runı Weerasoorıya (June 2009), "Identification of Effective Management Practices and Technologies for Lessons Learned Programs in the Construction Industry" Journal of Constrcution Engineering and Management Volume 135, Issue 6, pp. 531-539.

David W. Halligan, Weston T. Hester, and H. Randolph Thomas (1987), "Managing Unforeseen Site Conditions" Journal of Construction Engineering and Management, Vol. 113, No. 2, June 1987, pp. 273-287.

D. A. Langford, P. Kennedy, and J. Somerville (1992), "Contingency management of conflict: analysis of contract interfaces," in Construction Conflict Management and Resolution Conf., U.K.

D. J. Yates, (1998), Conflict and Dispute in the Development Process: A Transaction Cost Economic Perspective. Retrieved from http://business2.unisa.edu.au/

Earley, J (1970), An efficient context-free parsing algorithm. Communications of the ACM pp. 94-102. 
Edwin H. W. Chan and Henry C. H. Suen,(2005), Disputes and Dispute Resolution Systems in Sino-Foreign Joint Venture Construction Projects in China, Vol. 131, No. 2, pp. 141-148.

Fenn, P., Lowe, D., and Speck, C. (1997). "Conflict and dispute in construction." Construction Management and Economics, pp. 513-518.

Groton, J. P. 1997. "Alternative Dispute Resolution in the Construction Industry." Dispute Resolution Journal, Summer, 49-57.

Hewit, (1991), Winning Construction Disputes-Strategic Planning for Major Litigation. London, U.K.: Ernst and Young Press.

John Murdoch and Will Hughes (2000), Construction Contract: Law and Management, London: Spon Press.

John M. Nicholas, Herman Steyn (2008), Project Management for Business, Engineering, and Technology pp. 503-550.

J.Kolodner (1993), Case-Based Reasoning, Morgan Kaufmann Publishers, Inc.

Leake D. (Ed.) (1996), Case-Based Reasoning: Experiences, Lessons, and Future Directions. Menlo Park: AAAI Press/MIT Press.

M. H Jeffery, (2002), Ineffective Communication: Common Cause of Construction Disputes, ABA Lehal NotesVol.13, No.2.

M. Smith (1992), "Facing up to conflict in construction," in Proc. UMISTConf. pp. 120125.

Mitropoulos, P., Howell, G. (2001), "Model for understanding, preventing, and resolving project disputes", Journal of Construction Engineering and Management, Volume 127 Issue 3 , pp.223-233

Mark Marlin (2008), Implementing an Effective Lessons Learned Process in a Global Project Environment.

Peter R. Hibberd, Paul Newman (1999), "ADR and adjudication in construction disputes", Blackwell Science Publisher

Rissland, E., Kolodner, J., and Waltz, D. (1989), "Case-based reasoning" In Hammond, K., (Ed.), Proceedings of the DARPA Case-Based Reasoning Workshop, 1, 13. San Mateo: Morgan Kaufmann Publishers, Inc. 